DYNAMICS OF DEMOCRACY AID ALLOCATION:

FROM DEMOCRATIC DONORS TO AUTHORITARIAN REGIMES

\author{
A Dissertation \\ presented to \\ the Faculty of the Graduate School \\ University of Missouri \\ In Partial Fulfillment \\ of the Requirements for the Degree \\ Doctor of Philosophy \\ by \\ DONGJIN KWAK \\ Dr. Heather-Leigh Ba and Dr. Bryce W. Reeder, Dissertation Supervisors
}

JULY 2021 
The undersigned, appointed by the Dean of the Graduate School, have examined the dissertation entitled

\section{DYNAMICS OF DEMOCRACY AID ALLOCATION: FROM DEMOCRATIC DONORS TO AUTHORITARIAN REGIMES}

presented by Dongjin Kwak, a candidate for the degree of Doctor of Philosophy of Political Science, and hereby certify that in their opinion it is worthy of acceptance.

Professor Heather-Leigh Ba

Professor Bryce W. Reeder

Professor Stephen L. Quackenbush

Professor Jonathan Krieckhaus

Professor Saku Aura 


\section{ACKNOWLEDGEMENTS}

First of all, I wish to express sincere gratitude to my advisor, Professor Heather-Leigh Ba and Bryce W. Reeder, for their vision and direction. Their priceless gift to me was not just skills and knowledge, but also an unwavering moral support through every stage of my doctoral studies. Their teachings and encouragement will continue to instruct and inspire long beyond my years as a graduate student.

I would also like to thank my committee members Dr. Stephen L. Quackenbush, Dr. Jonathan Krieckhaus, and Dr. Saku Aura for their support and encouragement.

A very special thanks are also reserved for my cohort, Dr. Aaron Kushner, Dr. Kather-

ine Becerra Valdivia, and Dr.Yuko Sato. They always encouraged and inspired me to move forward. I was happy to go through a long journey of graduate life with you all. Especially, I would like to give special thanks to Aaron, who read all my works. 


\section{Contents}

ACKNOWLEDGEMENTS $\quad$ ii

LIST OF FIGURES $\quad$ vi

LIST OF TABLES vii

$\begin{array}{ll}\text { ABSTRACT } & \text { ix }\end{array}$

CHAPTER

1 Introduction 1

1.1 Democracy Promotion and Democracy Aid . . . . . . . . . . . . 3

1.2 Puzzling Questions . . . . . . . . . . . . . . . 7

1.3 Types of Democracy Aid . . . . . . . . . . . . . . . . 11

1.4 The Trend of Democracy Aid . . . . . . . . . . . . . . . . 18

1.4.1 The Patterns of OECD DAC Donors . . . . . . . . . . . . . 18

1.4.2 The Patterns of the U.S. . . . . . . . . . . . . . 22

1.5 Organization of the Dissertation $\ldots \ldots \ldots$. . . . . . . . 30

2 Distribution Mechanisms of Foreign Aid 34

2.1 Willingness, Constraints, Opportunities, and Threats . . . . . . . . . . 35 
2.2 Donors' Interests on Democracy Aid . . . . . . . . . . . . . . . 42

2.2.1 Why Do Donors Want to Provide Democracy Aid? . . . . . . . 43

2.2.2 Donors' Strategic Choice on Democracy Aid . . . . . . . . . 45

2.3 Recipients' Preference on Democracy Aid . . . . . . . . . . . . . . . . 49

2.3.1 Authoritarian Regimes and Democracy Aid Regime Compatibility 52

2.3.2 Strategic Response of Authoritarian Regimes Toward Democracy

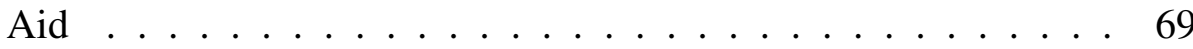

3 The Supply Side: How does the U.S. Distribute Foreign Aid? 74

3.1 U.S. Democracy Aid Allocation $\ldots \ldots \ldots$. . . . . . . . 76

3.2 Research Design . . . . . . . . . . . . . . . . . . . . . . . 80

3.2.1 Dependent Variables: Democracy Aid . . . . . . . . . . . 80

3.2.2 Independent Variables: Donor Interests . . . . . . . . . . . . . 82

3.2.3 Control Variables . . . . . . . . . . . . . . . . . . . 85

3.3 Empirical Results . . . . . . . . . . . . . . . . . . . 85

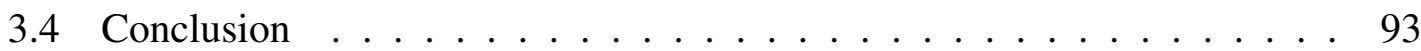

4 The Demand Side: Recipient Influence on Democracy Aid Allocation 96

$4.1 \quad$ Research Design . . . . . . . . . . . . . . . . . . . . . . . . 100

4.1.1 Dependent Variables: Democracy Aid . . . . . . . . . . . . 100

4.1.2 Independent Variables: Political Instability . . . . . . . . . . 101

4.1.3 Control Variables . . . . . . . . . . . . . . . . . . 105

4.2 Empirical Results . . . . . . . . . . . . . . . . . . . . . 106

4.3 Democracy aid to Cambodia and Myanmar . . . . . . . . . . . 112 
4.4 Conclusion . . . . . . . . . . . . . . . 115

5 Conclusion

A Summary Statistics of Variables

B Classification of Democracy Aid Subtypes

C Additional Models for Ch.3

D Additional Models for Ch.4 


\section{List of Figures}

1.1 Trend of Democracy Aid by Recipient Regime Types (1990-2013) . . . . 8

1.2 U.S. Democracy Aid to Jordan in 2009 and 2012 . . . . . . . . . . . . 9

1.3 Democracy Aid By Subtypes (1990-2013, OECD) . . . . . . . . . . 15

1.4 U.S. Democracy Aid By Subtypes (1990-2013) . . . . . . . . . . . . . . 17

1.5 Trend of Foreign Aid of OECD DAC Donors (1980-2013) . . . . . . . . 18

1.6 Trend of Democracy Aid of OECD DAC Donors (1973-2013) . . . . . . 19

1.7 Donors of Foreign Assistance (1973-2013) . . . . . . . . . . . . . . . . . 20

1.8 Trend of Foreign Aid of OECD DAC donors the U.S. (1990-2013) . . . . 22

1.9 Trend of Democracy Aid of the U.S. (1990-2013) . . . . . . . . . . . 24

1.10 Democracy Aid by Authoritarian Regime Types (1990-2013) . . . . . . . 29

2.1 Delivery Mechanism of Foreign Assistance . . . . . . . . . . . . . 40

2.2 Delivery Mechanism of Foreign Assistance . . . . . . . . . . . . . 41

3.1 U.S. Democracy Aid Allocation by Recipient Regime Types (1980-2013) 78

3.2 Regime-Compatible Democracy Aid Allocation (1990-2013) . . . . . . . 79

3.3 Predicted Regime-compatible Democracy Aid . . . . . . . . . . . . . . 91

4.1 Democracy Aid Allocation $(2003-2013) \ldots \ldots$. . . . . . . . . 113 


\section{List of Tables}

1.1 Top 20 Recipient Countries of the OECD DAC Donors and the U.S.

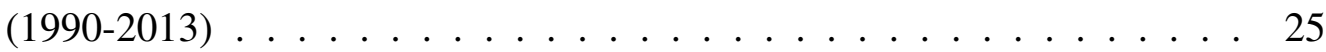

2.1 Donors' Interests and Volume of Democracy Aid . . . . . . . . . . . . 48

2.2 Authoritarian Regime Types and Democracy Aid . . . . . . . . . . . 55

3.1 Prais-Winsten Estimations on Total of Regime-Compatible Democracy Aid 86

3.2 Prais-Winsten Estimations on Ratio of Regime-Compatible Democracy Aid 90

4.1 Fixed Effect Models with CSO Repression Measure . . . . . . . . . . . . 107

4.2 Fixed Effect Models with Political Terror Measure . . . . . . . . . . . . . 110

A.1 Chapter 3. Summary Statistics of Variables . . . . . . . . . . . . . . . . 129

A.2 Chapter 3. Correlation Table on Independent Variables _ . . . . . . . . 130

B.1 Democracy Aid Sub-types by OECD DAC Classification . . . . . . . . . 131

C.1 Random Effect Models . . . . . . . . . . . . . . . . . . . 133

C.2 Random Effect Models . . . . . . . . . . . . . . . . . . . . . 134

D.1 Fixed Effect Models (CSO Repression $\times$ Military Aid) . . . . . . . . . 136

D.2 Fixed Effect Models (Political Terror $\times$ Military Aid) . . . . . . . . . . . 137 
D.3 Fixed Effect Models (CSO Repression $\times$ Military Aid (Dummy) $\ldots \ldots 138$

D.4 Fixed Effect Models (Political Terror $\times$ Military Aid (Dummy) . . . . . 139 


\title{
Dynamics of Democracy Aid Allocation \\ : From Democratic Donors to Authoritarian Regimes
}

\section{Dongjin Kwak}

Dr. Heather-Leigh Ba and Dr. Bryce W. Reeder, Dissertation Supervisors

\begin{abstract}
The purpose of this thesis is to analyze democracy aid allocation mechanisms between Western donors and authoritarian regimes in recipient countries. The theoretical mechanism explains how strategic choices of donors and recipient countries based on their interests affect the composition of democracy aid. As a part of democracy promotion policy, Western donors have increased democracy aid after the end of the Cold War. They provide various types of democracy aid targeting the advancement of democratic institutions, practices, and norms in authoritarian regimes. I classify democracy aid into two types-regime-compatible democracy aid and regime-incompatible democracy aid based on authoritarian regimes' preference regarding democracy aid. Then, I discuss that donors' strategic choice based on security and/or economic interests changes the shape of democracy aid patterns.
\end{abstract}

The empirical findings from the analyses of U.S. democracy aid to authoritarian regimes from 1990 to 2013 support my arguments. The U.S. increased regime-compatible democracy aid to their client states. Moreover, authoritarian regimes secure more regimecompatible democracy aid using their leverage over the U.S., when they have a higher 
political instability. The findings suggest that the strategic choices of donors and recipient countries affect decisions on types of democracy aid and shape the democracy aid allocation patterns. 


\section{Chapter 1}

\section{Introduction}

During the Arab Spring in 2011, there were a series of heavy anti-government protests, but these did not bring down the Abdullah II regime. King Abdullah II dismissed protestors by reshuffling the government and promising political reforms. When serial protests swept Jordan, the U.S. supported to King Abdullah II over the protestors, announcing that “We[The State Department] support King Abdullah II's roadmap for reform and the aspirations of the Jordanian people to foster a more inclusive political process that will pro-

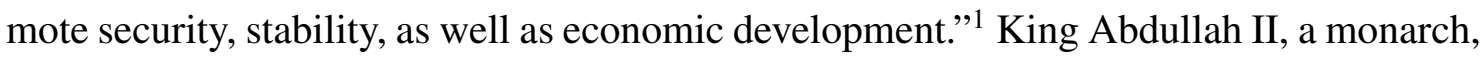
is a long-lasting major ally of the U.S. in the Middle East. The political survival of King Abdullah II is necessary for U.S. security interests in the region.

Jordan has been one of the top recipients of Western donors' democracy aid programs. Western donors put significant effort into promoting democratic institutions and norms in Jordan. According to the Aiddata (Tierney et al. 2011), Jordan received 2.1 billion U.S. dollars from 1990 to 2011 from the OECD DAC donors. ${ }^{2}$ Remarkably, the U.S., an old

\footnotetext{
${ }^{1}$ Mark C. Toner, U.S. Department of State, 11/15/2012, “Daily Press Briefing” https://2009-2017.state. gov/r/pa/prs/dpb/2012/11/200598.htm (Retrieved: 6.25.2021)

${ }^{2}$ If not otherwise specified, all aid values that come from AidData are provided in constant U.S. dollars in 2011 in this dissertation.
} 
friend of King Abdullah II, contributed 1.3 billion dollars under the name of democracy aid. However, despite these long-time efforts of Western donors to promote democracy in Jordan, donor nations failed to capitalize on the opportunity for democratization during the Arab Spring.

Donors, including bilateral and multilateral donors, provided aid for promoting democracy (hereafter "democracy aid") in a recipient country after World War II. As a tool of democracy promotion policy, donor countries have increased their effort over the decades. Particularly, Western donors expanded democracy aid programs since the 1990s. Donors have allocated 0.2 billion dollars under the name of democracy aid in 1980 and increased up to 16 billion dollars in 2013.

However, despite the efforts of Western donors on democracy aid, the Jordan case shows that democracy aid is not effective for promoting democracy. Despite the lengthy support of donors, it seems like democracy aid is ineffective for promoting democracy aid recipient countries. Jordan stays in an authoritarian regime, and the democratic conditions have not been improved during the period (Marshall \& Gurr 2020). Also, as like the U.S., donors may have different interests in a recipient country, and the donor-recipient relationship affects democracy promotion policy and democracy aid allocation patterns.

The Jordan case raises questions on democracy aid allocation mechanisms to authoritarian regimes. Although democracy aid has different characteristics from general development aid, scholarships do not shed much light on its delivery mechanisms. In this dissertation, I try to answer why authoritarian regimes accept democracy aid and how donors deliver democracy aid to authoritarian regimes. My theoretical arguments explain 
democracy aid allocation patterns. It also has implications to the questions around the effectiveness of democracy aid and the practice of democracy aid.

\subsection{Democracy Promotion and Democracy Aid}

Promoting democracy is one of the core foreign policy goals for most prominent donors of foreign assistance. The end of the Cold War was a critical turning point in how donors offered foreign aid. The collapse of the Soviet Union filled Western democracies with confidence in the ascendancy of democracy. For Western donor nations, promoting democracy abroad became a core foreign policy. For instance, President Clinton proclaimed in his first inaugural address that "[o]ur hopes, our hearts, our hands, are with those on every continent who are building democracy and freedom.”3 Echoing Clinton's sentiments, the European Union (EU) established the Common Foreign and Security Policy (CFSP) in 1993, aimed at "preserving peace, strengthening international security, promoting international cooperation and developing and consolidating democracy, the rule of law and respect for human rights and fundamental freedoms." ${ }^{* 4}$ Other prominent donors like Japan, Canada, Australia, and South Korea have also the promotion of democracy as a key element of their international role. ${ }^{5}$

\footnotetext{
${ }^{3}$ Govoinfo,"Inaugural Address, Monday January 20, 1997” https://www.govinfo.gov/content/pkg/ PPP-1997-book1/pdf/PPP-1997-book1-doc-pg43.pdf (Retrieved: 6.25.2021)

${ }^{4}$ European Union, "Foreign and Security Policy," https://europa.eu/european-union/topics/ foreign-security-policy_en (Retrieved: 6.25.2021)

${ }^{5}$ Governments or leaders of these countries have referred promoting democracy is a part their foreign policy.For instance, former Canadian Prim Paul Martin defined 'advancing democracy' is a part of foreign policy goals in the "Canada's International Policy Statement (IPS): A Role of Pride and Influence in the World" in 2005 (http://aix1.uottawa.ca/ rparis/IPS_2005.pdf (Retrieved: 6.25.2021)). Australia also demonstrate democracy promotion Asia-pacific area as a liberal democracy from the first Foreign and Trade Policy White Paper in 1997 (http://repository.jeffmalone.org/files/foreign/In_the_National_Interest. pdf(Retrieved: 6.25.2021)). Japan stipulated democracy promotion is an basic philosophy in their Official Development Assistance Charter in 1992. (Ministry of Foreign Affairs of Japan, "Japan's Official Development Assistance Charter." https://www.mofa.go.jp/region/n-america/us/q\&a/oda/3.html (Retrieved:
} 
While Western democratic countries share a normative commitment to expanding democracy around the globe, many donors prioritize security and economic interests over promoting democracy for its own sake (Remmer 1998, Milner \& Kubota 2005). Some donating countries have seen democracy promotion as an intermediate foreign policy goal, used to achieve greater security or economic goals (Maoz \& Russett 1993, Bueno de Mesquita et al. 1999). For example, President Clinton declared in 1994 that "[u]ltimately, the best strategy to ensure our security and to build a durable peace is to support the advance of democracy elsewhere."

Western countries utilize various policy forms for democracy promotion, such as diplomatic pressure, foreign aid, economic sanctions, and military intervention, economic sanctions (Schraeder 2003). However, some policy forms are not clear that the primary goal of policies is democracy promotion because both normative motivations and security and economic interests drive democracy promotion. Also, countries frequently claim democracy promotion as political rhetoric to justify their realpolitik purposes. For instance, when the U.S. invaded Panama in 1989, George H.W. Bush announced that "[t]he goals of the United States have been to safeguard the lives of Americans, to defend democracy in Panama." However, there are criticisms on the invasion of Panama that it is for control of the Panama Canal for U.S. economic and security interests. As a result, it makes it hard to measure the effectiveness of democracy promotion efforts.

The most direct and significant effort for democracy promotion is democracy aid that is aid for promoting democracy in recipient countries (Bush 2015). In general, all foreign aid can be considered as democracy aid depending on the perspective on democracy $6.25 .2021))$ 
promotion. According to Modernization theory, economic development drives democracy promotion by supporting socioeconomic features such as middle class, education, and urbanization (Lipset 1959, Apter 1965, Epstein et al. 2006). Thus, any foreign aid which is targeting socioeconomic development in a recipient country can be democracy aid. The U.S. provided foreign aid based on modernization theory during the 1960s (Carothers 2000). However, this approach has a problem in that it assumes a long theoretical pathway between foreign aid from donors and democratization in recipient countries. Furthermore, the effect of socioeconomic developments on democracy is still ambiguous (Przeworski et al. 2000, Robinson 2006, Boix 2011).

I define democracy aid as a type of foreign assistance that promotes the advancement of democratic institutions in recipient countries by bolstering social and political institutions, practice, and norms favorable to democracy. From the minimalist perspective, democracy is a political system ruled by people elected via competitive elections (Schumpeter 1942). However, free and fair elections are not the only requirement of democracy. There are various forms of democracies; these have different ideological and institutional components (Held 2006). For instance, Robert Dahl's requirements for democracy included free and fair elections, freedom of organization, freedom of expression, a non-governmental source of information, political parties, and independent interest groups (Dahl 1989). Scholars also consider other components key conditions for democracy, such as human rights, civil liberties, minority rights, rule of law, and horizontal accountability (Coppedge et al. 2011, Teorell 2010, Welzel \& Inglehart 2006, Munck \& Verkuilen 2002). 
Therefore, when donors provide democracy aid, they favor programs designed to bolster democratic institutions in a recipient country. The objectives are clear how to define democracy and democratization. In practice, each donor develops their own classification systems for what counts as democracy aid. The most prominent donor of democracy aid, the United States, divides democracy aid programs into four categories: rule of law, governance, civil society, and elections and political processes (USAID 1998). OECD Development Assistance Committee (DAC) also provides general democracy aid classification to donors. OECD DAC Creditor Reporting System (CRS), a self-reporting system of donors on foreign aid allocation, categorizes democracy assistance into fifteen categories: public sector policy and administrative management, legal and judicial development, democratic participation, and civil society, elections, and legislatures, and political parties.

The variety of democracy aid programs have two implications on democracy aid allocation. First, the variety of democracy programs gives more room to donors to have a strategic choice on democracy aid. Donors can change the features of democracy aid by changing the programs. If there are different motivations involve in democracy aid allocation, donors can pursue different goals by adjusting the programs of democracy aid. Donors have a selective approach to democracy aid by recipient countries. Recipient countries have different sociopolitical conditions and institutional backgrounds. Particularly, authoritarian regimes quite different political institutions and survival mechanisms by their types (Levitsky \& Way 2010b, Diamond 2002). Donors can allocate democracy more strategically targeting different dimensions in recipient countries. It also gives more negotiation power in the foreign aid allocation negotiation. Second, it has an implication 
to the effectiveness of democracy aid. The composition of democracy aid programs can be a matter of the effectiveness of democracy aid. The volume of democracy aid is an important matter for the effectiveness of democracy promotion, but it also important to the effectiveness of what programs are incorporated in the democracy aid packages.

\subsection{Puzzling Questions}

Like Jordan, many authoritarian regimes are survival even if they have received democracy aid from Western donors. Figure 1.1 describes democracy aid flow by regime types from 1990 to 2013 . . The most interesting pattern is that authoritarian regimes are the primary recipient of democracy aid from OECD DAC donors. It shows that OCED DAC donors have increased democracy aid to authoritarian regimes consistently after the end of Cold War even if there is some fluctuation. During this period, authoritarian regimes have more democracy aid from OECD DAC members than democratic regimes. In 2007, bilateral democracy aid from all OECD DAC donors exceeded 7.5 billion dollars, and they delivered around 5 billion dollars to authoritarian regimes. The U.S., the largest democracy aid donor, also has similar patterns that authoritarian regimes are the primary recipient of U.S. democracy aid.

The patterns raise a question on democracy aid allocation: why do authoritarian regimes have democracy aid? Theoretically, democracy aid aims democracy promotion in a recipient country. It supports democratic movements in authoritarian regimes or them to adopt democratic institutions. If donors allocate democracy only for democracy promotion, authoritarian leaders in recipient countries may perceive democracy aid as an external threat to their political survival. At least, democracy aid can destabilize authoritarian regimes by 
increasing democratic movements. However, authoritarian regimes have had democracy aid as like accepting other foreign aid for extra resources. It seems like it is not effective enough to promote democracy in authoritarian regimes. Instead, authoritarian regimes are likely to consider democracy aid as an opportunity for extra funding for their governments. Thus, we need to think about the characteristics of democracy aid whether it is an effective apparatus for democracy promotion or a sort of aid for an extra resource to authoritarian regimes. This question is essential to the argument on the effectiveness of democracy aid.

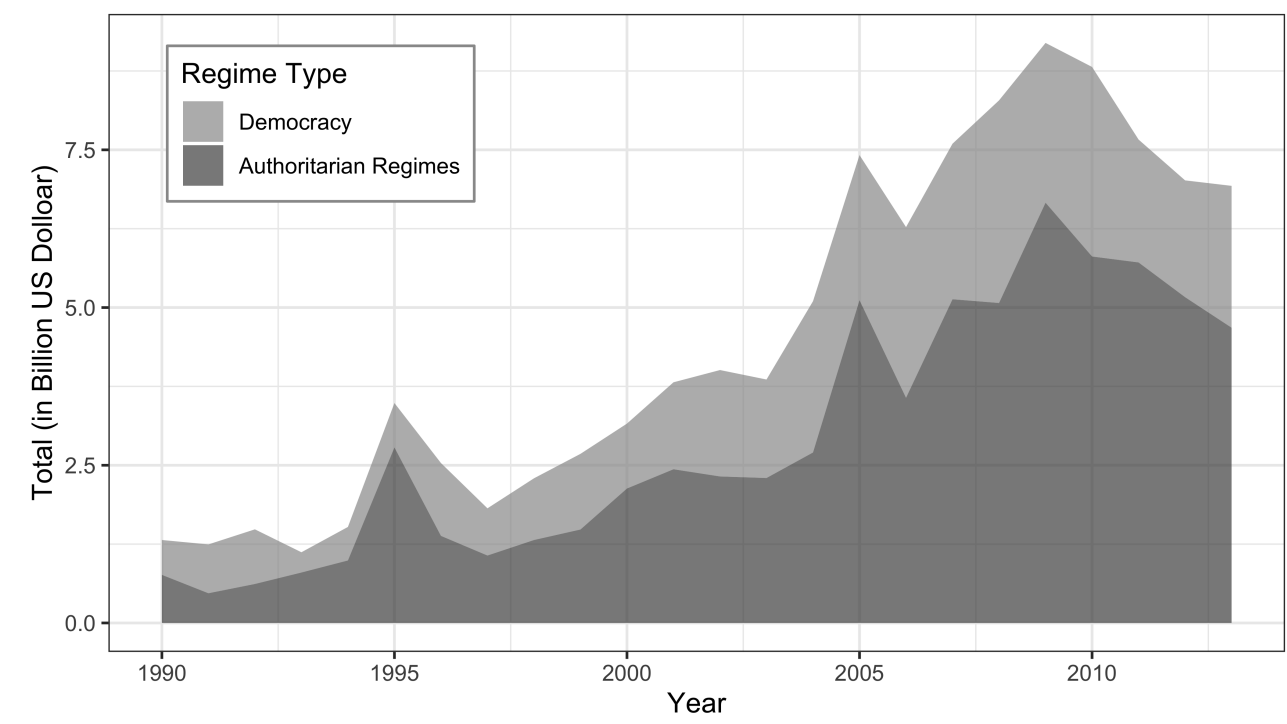

Figure 1.1: Trend of Democracy Aid by Recipient Regime Types (1990-2013) Source: AidData 3.1 (Tierney et al. 2011)

Regarding the Jordan case, another interesting pattern is on the composition of democracy aid. When the Arab spring swept Jordan between 2011 and 2012, the U.S. has increased foreign aid to Jordan rapidly. In 2009, the volume of U.S. democracy aid to Jordan was 38 million dollars. However, the U.S. has increased democracy aid to Jordan up to 310 
million in 2012. Ostensibly, the U.S. increased democracy aid to support the democratic movement in Jordan. However, the characteristics of the most of raised part of democracy aid during the Arab Spring is close to back to King Abdullah II regime rather than civil movement.

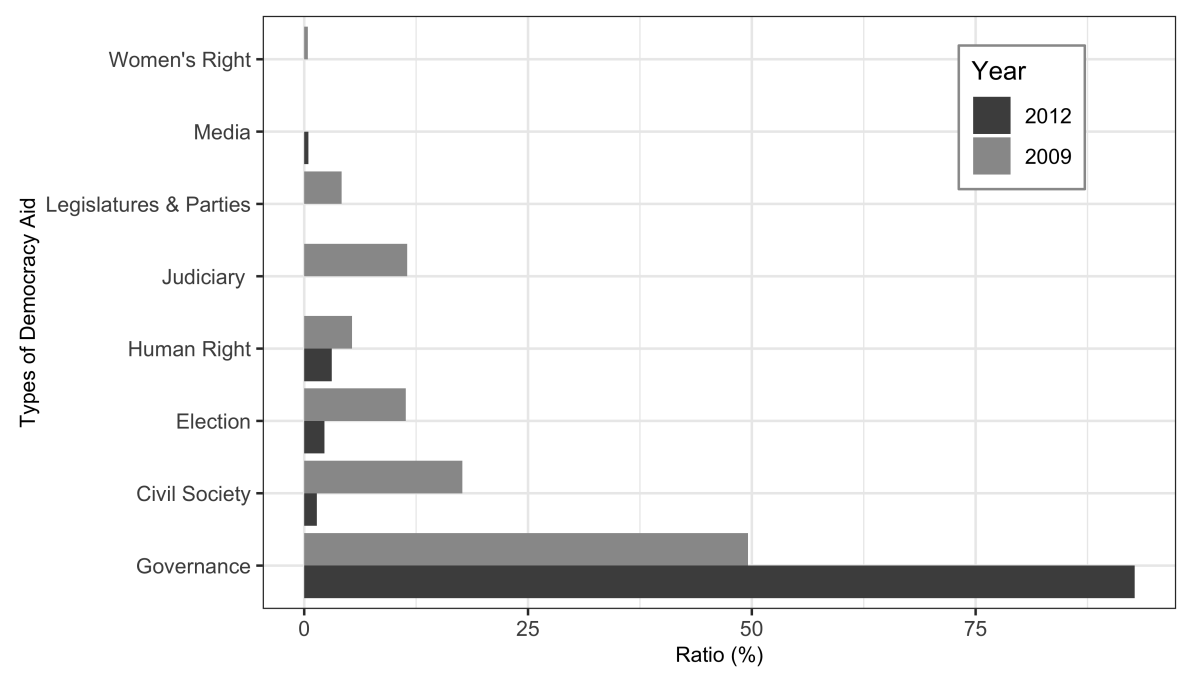

Figure 1.2: U.S. Democracy Aid to Jordan in 2009 and 2012

Source: AidData 3.1 (Tierney et al. 2011)

Figure 1.2 shows a composition of democracy aid programs between 2009 and 2012. Compared to 2009, the U.S. has increased democracy aid for good governance mainly delivered to recipient government and supporting good governance for better public service provision. However, the ratio of other democracy aid programs for civil society, human rights, and elections can enhance the social movements in Jordan. Although the U.S. increased democracy aid, they provided more favorable democracy aid to the King Abdullah II regime, an old friend of the U.S., rather than civilian democratic movements.

The U.S. democracy aid patterns to Jordan raises the second question on democracy aid allocation mechanisms: what factors make donors have different allocation strategies 
in democracy aid by recipient countries. Democracy promotion is not the only foreign policy goal of donors. They have different foreign policies, and donors can utilize democracy aid for their purpose. In this regard, the Jordan case shows how other national interests or preferences can change the democracy aid allocation patterns. It seems like donors have different strategic choices on the composition of democracy aid depending on their other foreign policy goals and interests. Also, as the U.S. provided more favorable democracy aid to the King Abdullah II regime during the Arab spring, donors' decisions on democracy aid can be affected by the domestic conditions of recipient countries.

To explain the interesting patterns of democracy aid, I develop theoretical arguments on democracy aid and its allocation. My theoretical argument is twofold. The first part of the argument emphasizes how donors' security or economic interests can distort democracy aid allocation to authoritarian regimes. Western donors have developed a different relationship with recipient countries depending on their interests. A typical difference in the status of two parties-Western donors are usually strong and recipient countries weak and undeveloped-makes donors have more leverage over the recipient countries in democracy aid allocation. I argue that how the donor-recipient relationship, which is based on the donors' interests, changes donors' choice of democracy aid programs.

The second part of the theoretical argument is the recipient countries' preference for democracy aid. The core concept is "regime compatibility," in which authoritarian regimes consider whether each democracy aid program is an opportunity or threat. Recipient regimes have different sociopolitical conditions. Particularly, authoritarian regimes have various political institutions and vulnerability to political challenges from internal 
and external factors. The main argument on the recipient side is that the different sociopolitical backgrounds make authoritarian regimes have different attitudes and preferences toward each democracy aid program.

\subsection{Types of Democracy Aid}

I define democracy aid as foreign aid targeting sociopolitical conditions in recipient countries for democracy promotion. Although the boundaries of the concept of democracy aid is still needs fleshed out (Carothers 2015), I consider specific foreign aid programs as "democracy aid" in which aid explicitly targets required institutions or core values for democracy in a recipient country. Therefore, I exclude foreign aid for economic development and disaster relief in recipient countries even if they can be considered democracy aid in promoting economic development from the modernization theory perspective.

Donors have developed various democracy aid programs. They have different perspectives on democracy and democratization, so that they have a different approach to democracy promotion (Carothers 2009a). If a donor considers democracy is a matter of free and fair elections, they are more likely to deliver democracy aid to core democratic institutions such as elections and political parties. On the other hand, if donors see democracy as more than political institutions encompassing democratic values and norms, their democracy aid programs are more likely to be oriented to civil society and human rights programs.

In my dissertation, I consider eight subtypes of democracy aid: governance, judiciary, election, legislature and political party, media, civil society, human rights, and woman right. Each type of democracy aid targets different dimensions of democracy. One block 
of democracy aid types is democratic institutions: governance, judiciary, election, and legislature and political party. These types aim to build an institutional foundation for democracy, such as effective and accountable governance system, rule of law, and competitive elections. The other block of democracy aid types aims at democratic values and popular sovereignty such as media, human rights, and civil society. It means that democracy is not only a political institution, but it is also a political system that ensures citizens' participation, freedom of expression and media, and human rights. In this section, I introduce how I define each type of democracy aid.

- Governance These programs are mainly for bureaucratic institutions. They aim to enhance public management systems and capacities. Good governance is necessary for the effective and efficient provision of public services as well as a stable political environment. It is important for the responsibility and accountability of regimes. These programs include aid programs for public finance management system, anticorruption institutions, monitoring system, domestic revenue mobilization policy, and human resource management system.

- Judiciary These programs are for the legal system, judicial system, police, and fire and rescue services. These programs mainly focus on the institutional building of the legal and judicial system. It organizes one set of rule of law in a country. Judiciary is a core institution in democracy for check and balance. Including professional legal education, these programs support various judicial techniques, systems, and procedures such as constitutions, legal reform, ombudsmen, and alternative dispute resolutions. 
- Civil Society These programs are for supporting the exercise of democracy and the participation of citizens beyond elections. It aims to educate citizens and to develop a civil society that is proper democracy. It includes programs to support organizations to engage public affairs and social problems in the recipient country. These programs support citizens' participation in the public sphere. It also contains civic educations on democratic values, human rights, citizenship.

- Election These programs aim to support free and fair elections. They support election administration system, election observations and monitoring programs, and voter education programs. The free and fair election is the most fundamental conditions for democracy.

- Legislatures and Political Parties These programs aim to strengthen democratic legislatures and party systems in a recipient country. It includes various programs such as Improving legislature bodies and committees, training programs for lawmakers, supporting party organizations, and training programs for communication and campaign strategies.

- Human Rights These programs are for promoting human right conditions in recipient countries. Donors provide supports to human rights institutions for children, victims of trafficking and torture, migrants, sexual minorities, and indigenous people. These include support programs for human right NGOs, human right educations, and human right activities in recipient countries. Human rights are a core value of democracy that is essential for life as a human being. Moreover, human rights are 
considered as a political right to participate in political decisions in democracy. ${ }^{6}$

- Media These programs are for supporting free and uncensored flow of information. Freedom of the press is one of the core values of democracy. Dahl also argues that an alternative source of information is a necessary condition for democracy (Dahl 1989). Authoritarian regimes want to control or censor sensitive information. All authoritarian regimes lack legitimacy so that they want to control information that can make their regime illegitimate or can promote civilian movements.

- Women's Right These programs are for supporting movements for women's right and ending violence against women. Donors deliver aid to organizations and institutions for women's right and gender equality. Also, they aim to fund promoting norms and attitudes, adopting politics and laws to prevent all forms of violence against women and girls. As a part of human rights, women's right is a core value of democracy and.

Figure 1.3 shows the composition of democracy aid programs of all OECD DAC donors between 1990 and 2013. OECD DAC donors delivered democracy aid for different domains in recipient countries. Regardless of recipients' regime type, the three most significant types of democracy aid are governance, judiciary, and civil society. Almost 85 percent of democracy aid of OECD DAC donors are these three types. Democracy aid of OECD DAC donors heavily weighted in favor of governance. Around 60 percent of democracy aid is governance type regardless of the recipient regime types. Judiciary

\footnotetext{
${ }^{6}$ UN, The Universal Declaration of Human Rights of 1948, Article 21. https://www.un.org/en/about-us/ universal-declaration-of-human-rights (Retrieved: 6.17.2021)
} 


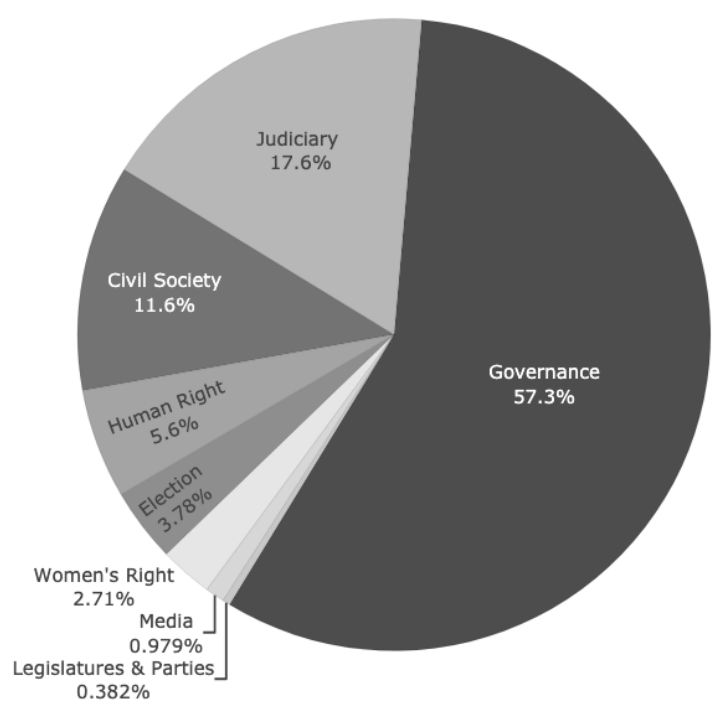

(a) OECD DAC to Democracy

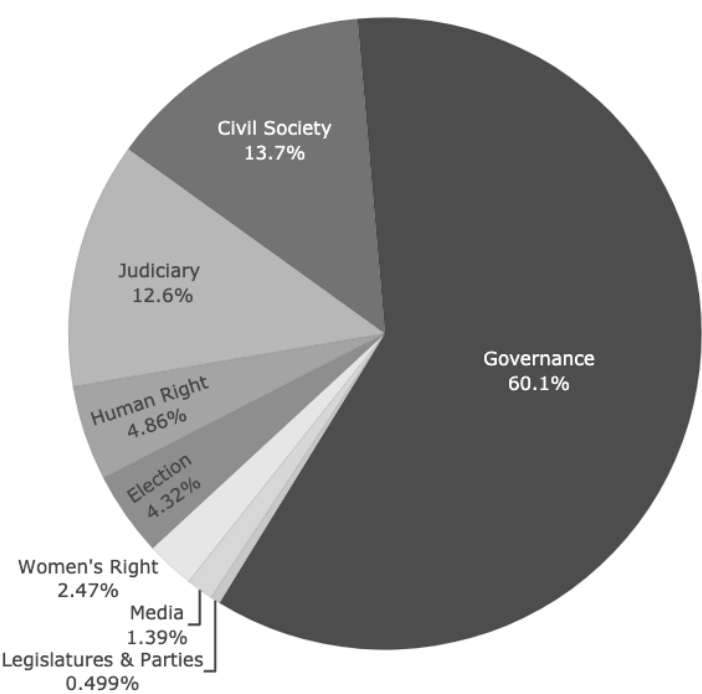

(b) OECD DAC to Autocracy

Figure 1.3: Democracy Aid By Subtypes (1990-2013, OECD)

Source: AidData 3.1 (Tierney et al. 2011)

and civil society are the two following largest programs. Democratic recipient countries have more Judiciary than authoritarian regimes. Finally, OECD DAC donors provide relatively small amounts of democracy aid to election, legislature and political parties, media, human rights, and women's right. They are less than 15 percent of democracy aid.

Figure 1.3 indicate that OECD DAC donors are oriented to democratic institutions rather than democratic norms and citizens' participation. They delivered less than 10 percent of democracy aid for human rights, women's right, and media programs. Almost two thirds of democracy aid is for governance and judiciary programs. It can be interpreted that OECD DAC donors promote democracy through institutional reforms, but it also seems like OECD DAC donors target visible institutions such as the government or judicial system. Also, they are easy to deliver to recipients regardless of regime types be- 
cause recipient governments are willing to have governance programs. An effective and efficient government system also gives benefits to the current government because it helps their ruling.

The figure also shows that OECD DAC donors delivered different democracy aid programs by recipient regime types. Although Figure 1.3 shows the marginal difference between democratic and authoritarian recipients, the composition of democracy aid is different. OECD DAC donors have different concerns or priority different priority on democracy promotion depending on recipient regime types. One significant thing is that OECD DAC donors allocate more governance programs to authoritarian regimes. This is because it is easy to deliver to authoritarian regimes, and authoritarian regimes are generally undeveloped than democracies so that they have more needs for a governance system.

Figure 1.4 describes the composition of U.S. democracy aid by regime types between 1990 to 2013. They have similar patterns with OECD DAC donors, but the U.S. concentrates more on particular programs such as judiciary and civil society programs. Around 50 percent of democracy aid is for governance programs. It is smaller than OECD DAC donors, and but the U.S. also delivered more governance programs to authoritarian regimes than democratic regimes. One big difference is that the U.S. more focused on Judiciary programs. Judiciary programs take 30 percent of democracy aid to democratic regimes and 25 percent of it to authoritarian regimes. They are almost twice bigger than OECD DAC donors. The U.S. is also more likely to allocate democracy aid targeting democratic institutions than democratic norms and civil participation. 


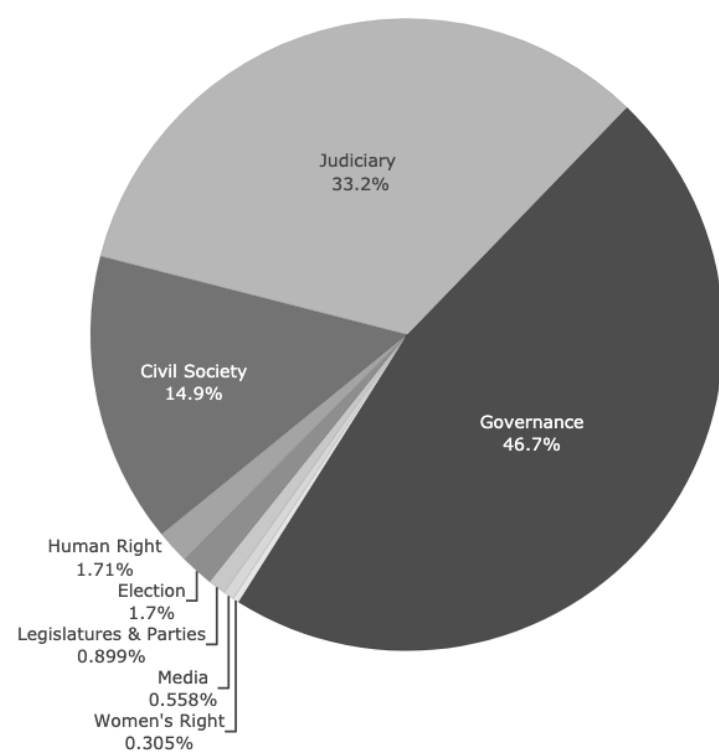

(a) U.S. to Democracy

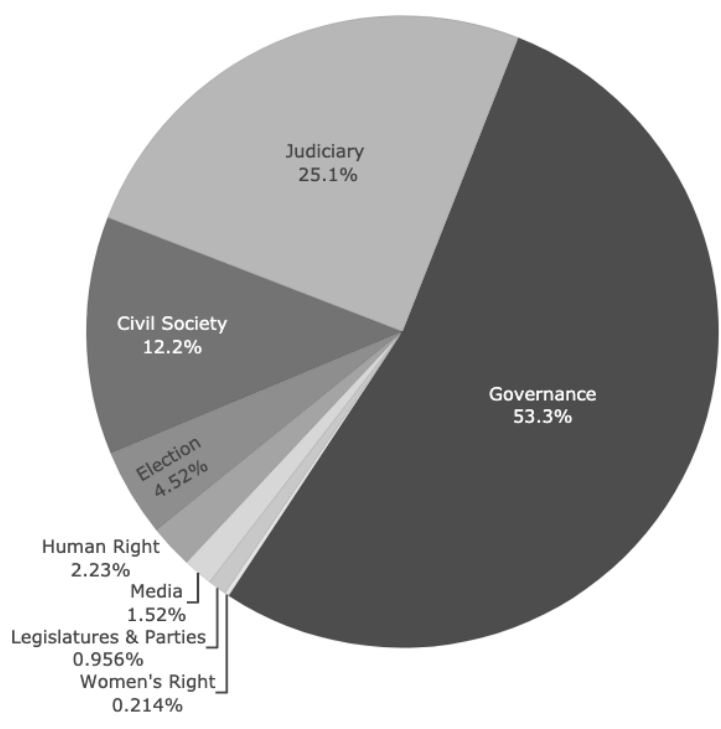

(b) U.S. to Autocracy

Figure 1.4: U.S. Democracy Aid By Subtypes (1990-2013)

Source: AidData 3.1 (Tierney et al. 2011)

The U.S. creates democracy aid with around 50 percent of governance type. It is smaller than OECD DAC donors. However, the U.S. focuses more on judiciary. More than 30 percent of democracy aid to democratic recipients is consists of judiciary. And other types of democracy aid have similar patterns with OECD DAC donors. Finally, the difference of democracy aid formulation between democracy and authoritarian regimes is more apparent when we focus on single donors. The U.S. creates democracy aid with governance types than ones for democratic regimes and reduces the proportion of Judiciary and civil society. Also, the U.S. provides more media types to authoritarian regimes than democratic regimes, even if the changes are slightly small. 


\subsection{The Trend of Democracy Aid}

\subsubsection{The Patterns of OECD DAC Donors}

Although democracy promotion is one of the foreign policy goals in most Western donors, democracy aid has been a small part of foreign aid. Figure 1.5 describes the overall foreign aid trend and bilateral democracy aid trend of OECD DAC donors. The trend of foreign aid from OECD DAC donors has an increasing trend from 1980. In 1980, foreign aid was around 40 billion U.S. dollars, but it exceeded 50 billion U.S. dollars in 1991 and reached 100 billion U.S. dollars in 2005. Donors also increased the volume of democracy aid from 1980. Democracy aid was .2 billion U.S. dollars in 1980. However, it exceeded 1 billion U.S. dollars in 1989. In 2010, democracy aid reached 9 billion U.S. donors.

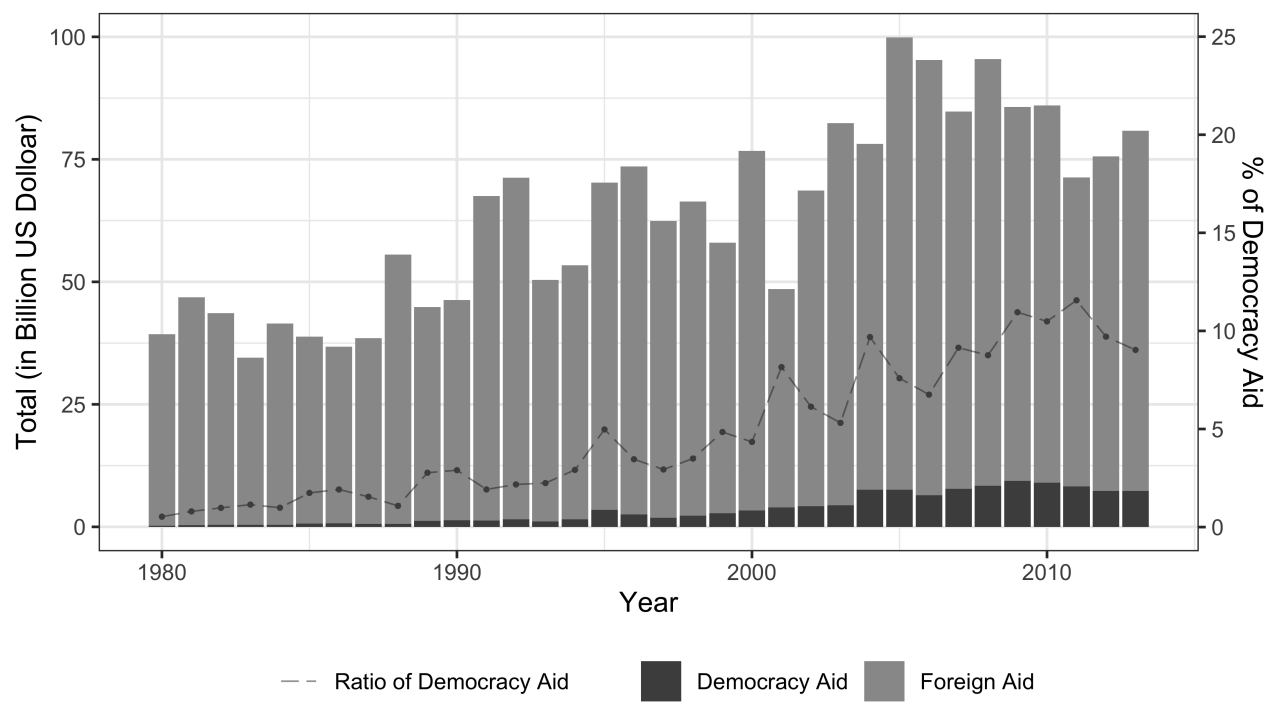

Figure 1.5: Trend of Foreign Aid of OECD DAC Donors (1980-2013) Source: AidData 3.1 (Tierney et al. 2011)

The proportion of democracy aid in foreign aid shows a more clear increasing trend of democracy aid. The dashed line in Figure 1.5 indicates the percentage of democracy in 
foreign aid. It shows that the proportion of democracy aid is around 1 percent of foreign aid in the 1980s. OECD DAC donors did not use democracy aid for democracy promotion. The foreign aid policy is more focused on economic development. However, donors increased democracy proportion around 3-4 percent in the 1990s. In the 2000s, around 10 percent of foreign aid was democracy aid. After the Cold War, the new international security environment allows that donors can utilize foreign aid for democracy promotion. OECD DAC donors have increased democracy aid in the foreign aid packages. The trend implies that OECD DAC donors are more likely to use foreign aid for democracy promotion.

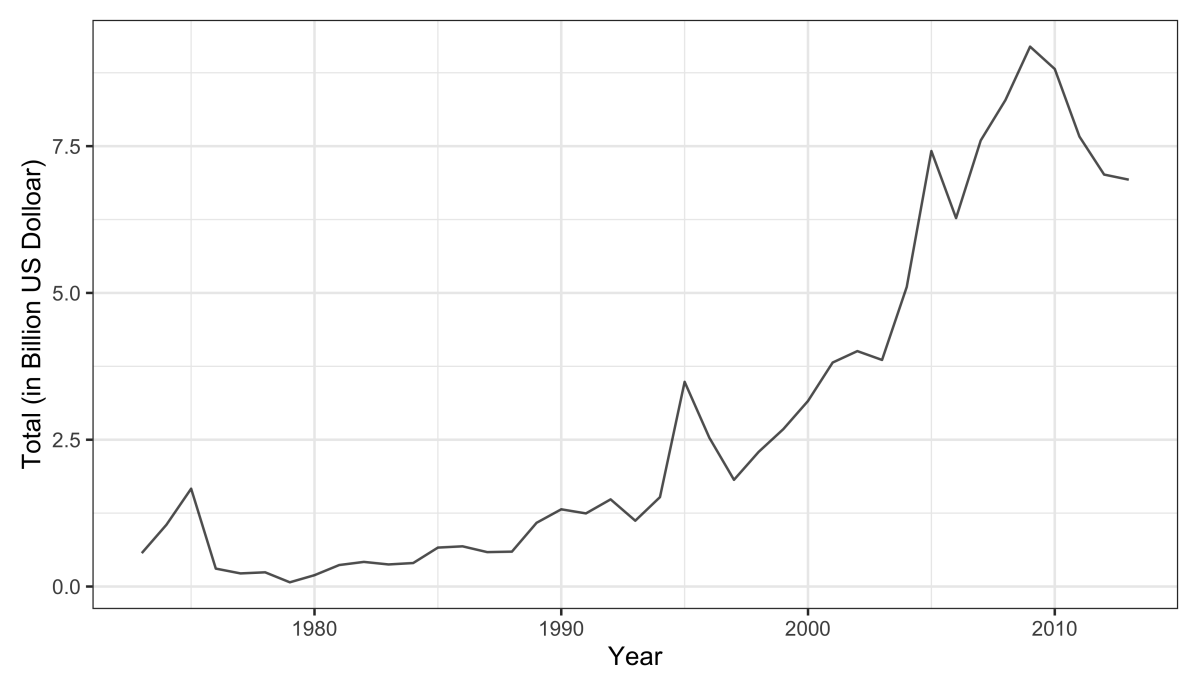

Figure 1.6: Trend of Democracy Aid of OECD DAC Donors (1973-2013)

Source: AidData 3.1 (Tierney et al. 2011)

Figure 1.6 shows more clear democracy aid flow from 1973 to 2013. It shows an increasing trend from the 1970s. In 1973, the total of democracy aid was around 660 million dollars. After that, democracy aid exceeded 1 billion dollars in 1989 and reached 10 billion dollars in 2004. in 2013, the total of democracy aid was more than 16 billion dol- 
lars in a year. OECD DAC donors have expanded democracy aid in each decade. Figure 1.6 also describes that the end of Cold War was a tipping point to democracy aid allocation. Democracy aid from OECD DAC donors has been increased dramatically since the 1990s. This trend indicates that the end of Cold War provided a new security environment to Western donors that they could take care of various issues like democracy promotion other than security issues. Donors have used democracy aid more for democracy promotion in the post-Cold War era.

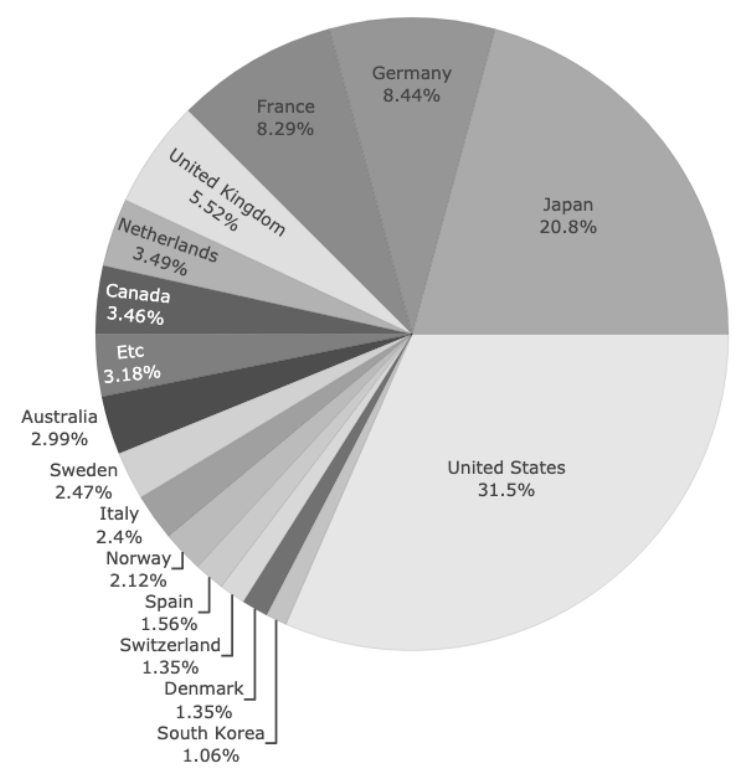

(a) Foreign Aid

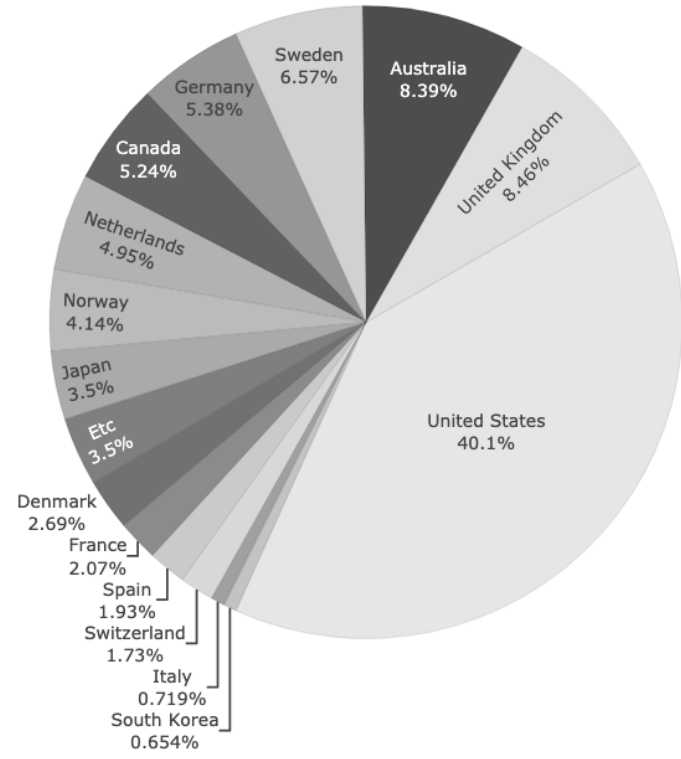

(b) Democracy Aid

Figure 1.7: Donors of Foreign Assistance (1973-2013)

Source: AidData 3.1 (Tierney et al. 2011)

Figure 1.7 shows the share of bilateral contribution by OECD DAC donors to foreign aid and democracy aid between 1973 and 2013. According to Figure 1.7 (a), the most prominent donor of foreign aid is the U.S. between 1973 and 2013. The U.S. contributed 
31.5 percent of foreign aid. During this period, the U.S. allocated 720 billion U.S. dollars. Other prominent donors are Japan (20.8\%), Germany (8.44\%), France (8.29\%), UK (5.52\%). These donors contributed around 70 percent of foreign aid. Except for Japan and South Korea, most of the top OECD DAC donors are from Western countries.

One trend of foreign aid is that the share of the traditional donor, such as the U.S., Japan, France, and Germany, decreases because of new donors. The interesting thing is that the number of donors is increased by decade. During the 1980s,16 OECD DAC donors contributed foreign aid, such as the U.S., Japan, France, Germany, and Canada. All donors are from Western donors except Japan. 19 OECD DAC donors provided foreign aid in the 1990s. Portugal, Belgium, and Spain joined OEDC DAC members. In the 2000s, 30 countries contributed foreign aid. Countries with experienced economic growth, such as Slovenia, South Korea, United Arab Emirates, Poland, and Greece, start contributing. Based on economic development, new donors contribute a significant amount of foreign aid short amount of time. For instance, South Korea contributed 1.06 percent of total foreign aid only between 2006 and 2013.

There are some different patterns of contribution in democracy aid. First, the most prominent donors are Western countries. The most prominent donor of democracy aid is the U.S. The U.S. contributed 40.1 percent of democracy aid. The total contribution of the U.S. 50.3 billion U.S. dollars during the period. After the U.S., the most prominent donors are United Kingdom (8.46\%), Australia (8.39\%), Sweden (6.57\%), and Germany (5.38\%). Although Japan is the second largest foreign aid donor, they are ranked 8th in democracy aid and contributed 3.5 percent of democracy aid. Second, some countries 
show more commitment to democracy aid. Compared to the overall contribution to foreign aid, Australia, Netherlands, and Nordic countries (Sweden, Norway, and Denmark) contributed a relatively larger proportion of democracy aid.

\subsubsection{The Patterns of the U.S.}

The most prominent foreign aid donor is the U.S. After World War II, the U.S. established the Marshall Plan to rebuild European countries destroyed during the war. The bipolar competition during the Cold War made the U.S. utilize foreign aid based on securityoriented motivations. Between the 1970s and 1980s, U.S. foreign aid was more oriented to support allies and maintain the anti-communist front. The U.S. supported corrupted dictators such as Mobutu in Zaire and Marcos in the Philippines because they are anticommunist. However, the end of Cold War has released the U.S. from security concerns. They could have more attention to other international issues.

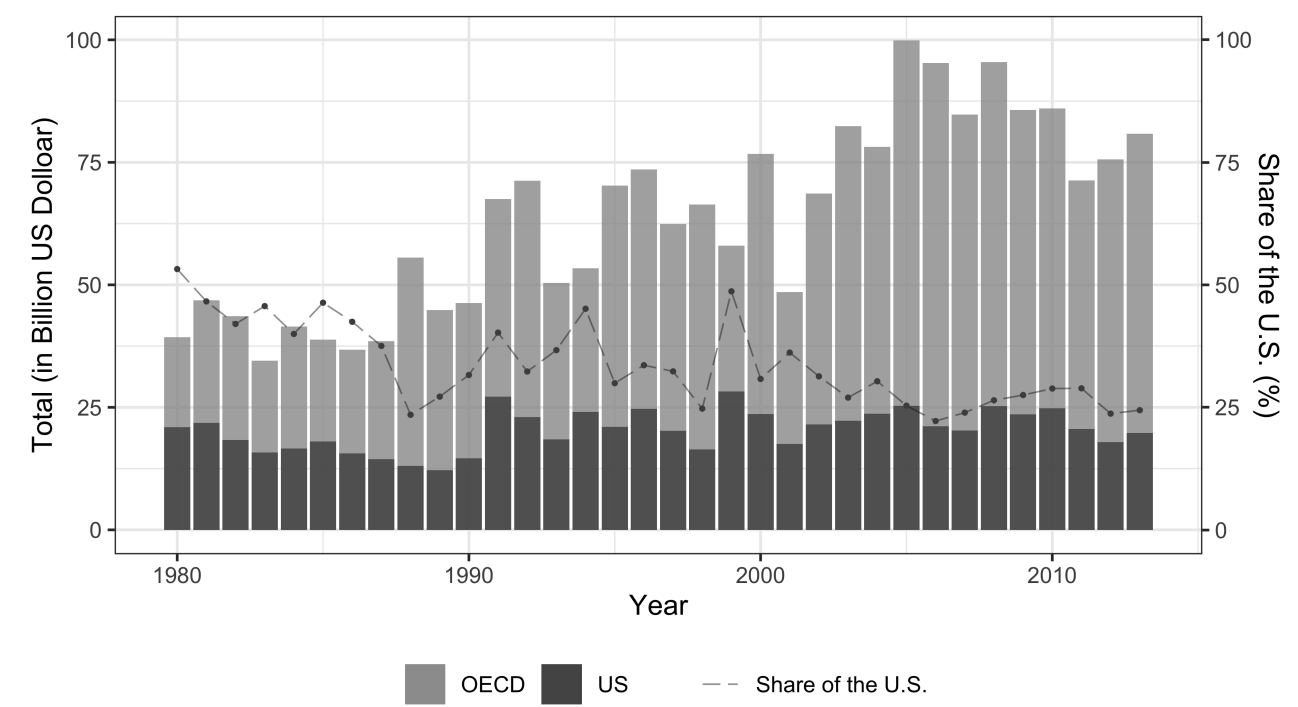

Figure 1.8: Trend of Foreign Aid of OECD DAC donors the U.S. (1990-2013) Source: AidData 3.1 (Tierney et al. 2011) 
Figure 1.8 describes the contribution of the U.S. to bilateral foreign aid from the OCEC DAC donors between 1980 and 2013. First of all, Although the U.S is still the most significant donor between the period, the volume of U.S. foreign aid has s static trend. There is some fluctuation, but the U.S. provided foreign aid between 15 and 25 billion U.S. dollars in the period. The U.S. contributed a similar ratio of budget for foreign assistance regardless of economic fluctuation. For instance, the U.S. contributed a similar amount of foreign aid during the Financial crisis of 2007-2008. Second, the share of the U.S. in foreign aid has a decreasing trend in this period. The U.S. contributed 52 percent of bilateral foreign aid in 1980, but it decreased to 25 percent in 2013. The increasing pattern of foreign aid is attributed to the other OECD DAC donors.

Although the U.S has gradually increased the volume of foreign aid, they increased democracy aid dramatically by decade. Figure 1.9 shows bilateral democracy aid flow of donors between 1980 and 2013. Both other OECD DAC donors and the U.S. have increased democracy aid since the 1980s. The volume of U.S. democracy aid was 94 million dollars in 1980. It was only 0.5 percent of the U.S. foreign aid. However, the U.S. increased it to 4.5 billion U.S. dollars in 2010. It implies that the U.S. utilizes democracy aid more for their foreign policy goals, including democracy promotion. Also, the share of the U.S. in democracy aid is significant. The U.S. has contributed around 40 percent of bilateral democracy aid in this period. The contribution of the U.S. has a decreasing trend during the 1990s because of increases of other donors, but it turned to an increasing pattern from the mid-2000s after the U.S. rapidly increased democracy aid than other donors. 


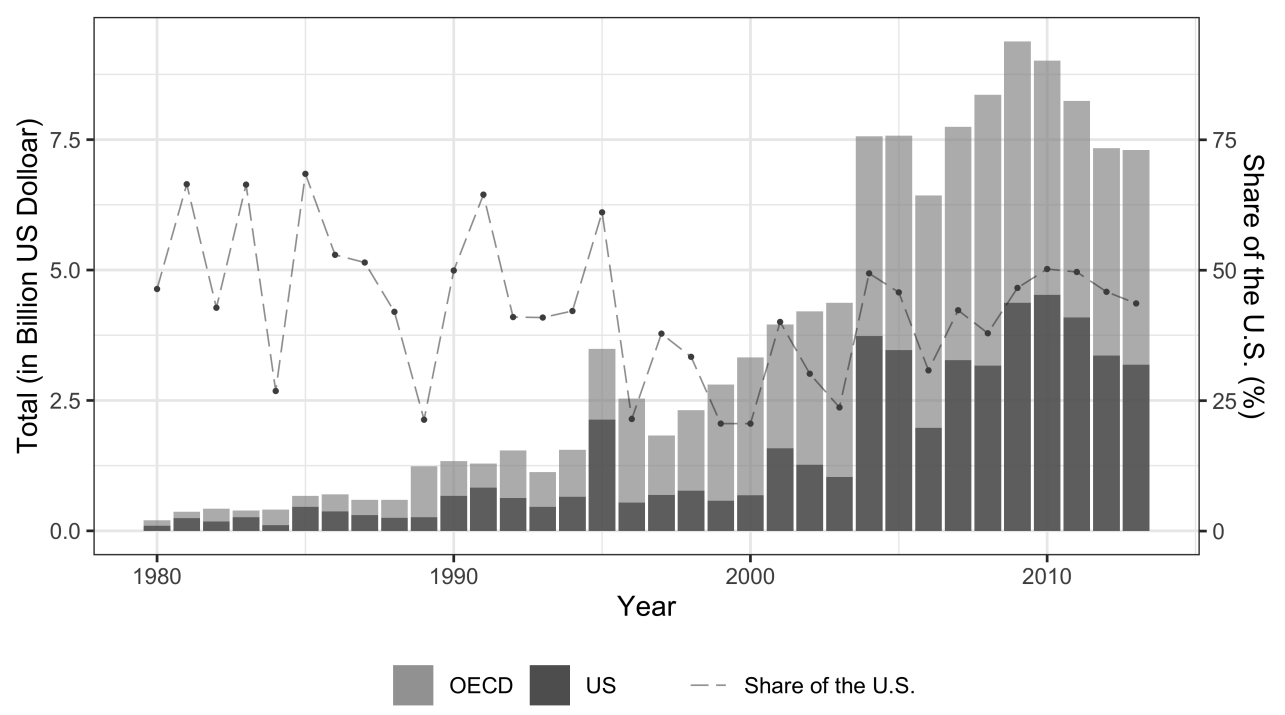

Figure 1.9: Trend of Democracy Aid of the U.S. (1990-2013)

Source: AidData 3.1 (Tierney et al. 2011)

\section{Recipients of the U.S. Foreign Assistance}

Table 1.1 presents the top recipient of foreign aid and democracy aid between 1990 and 2013. The recipient countries. First of all, OECD DAC donors seem like they have fewer concerns about the recipients' needs. Among 46 least developed countries (LDCs) in 2002, there are seven countries in the top recipients (UNCTAD 2004). ${ }^{7}$ Among the top 10 recipient countries, there are no LDCs. OECD DAC donors are more likely to consider other factors such as their security or economic interests than recipients' needs when they allocate foreign aid. Second, the top recipient of OECD DAC donors is similar to the U.S. recipient even if the rank order is different. Sixteen recipients are ranked in both the top 20 recipients of the U.S. and all OECD DAC donors because the U.S. contributed around 30 percent of foreign aid during the period. Also, it implies that donors have similar allo-

\footnotetext{
${ }^{7}$ The 7 LDCs in the OECD DAC recipient list are Afghanistan (11), Tanzania (12), Bangladesh (13), Ethiopia (15), DRC (16), Mozambique (17), and Uganda (18).
} 
cation patterns of foreign aid. One interesting thing is that although China was not on the list of the top recipient of the U.S., China is ranked the largest recipient of OECD DAC donors. It seems that the U.S. and other OECD DAC donors have different preferences on China regarding foreign aid allocation.

Table 1.1: Top 20 Recipient Countries of the OECD DAC Donors and the U.S. (19902013)

\begin{tabular}{l|l|l|l|l}
\hline \multirow{2}{*}{} & \multicolumn{2}{|c|}{ OECD DAC } & \multicolumn{2}{c}{ Democracy Aid } \\
\cline { 2 - 5 } & Total Aid & \multicolumn{1}{c}{ Democracy Aid } & Total Aid & \multicolumn{1}{c}{ Demaq } \\
\hline 2 & China & Afghanistan & Iraq & Iraq \\
\hline 3 & Indonesia & Iraq & Afghanistan & Afghanistan \\
\hline 4 & Pakistan & Pakistan & Russia & Egypt \\
\hline 5 & Egypt & Egypt & Pakistan & Jordan \\
\hline 6 & Vietnam & DRC & Indonesia & Haiti \\
\hline 7 & Turkey & Vietnam & Ethiopia & Russia \\
\hline 8 & Iraq & Bangladesh & Jordan & Sudan \\
\hline 9 & Morocco & Jordan & Sudan & Lebanon \\
\hline 10 & Nigeria & Mozambique & DRC & Bosnia \& Herzegovina \\
\hline 11 & Afghanistan & Bosnia \& Herzegovina & Haiti & Armenia \\
\hline 12 & Tanzania & Nigeria & Nigeria & Georgia \\
\hline 13 & Bangladesh & Uganda & Colombia & Indonesia \\
\hline 14 & Mexico & Haiti & Uganda & Liberia \\
\hline 15 & Ethiopia & China & Tanzania & Ukraine \\
\hline 16 & DRC & Morocco & Turkey & Cambodia \\
\hline 17 & Mozambique & Cambodia & Mexico & Nicaragua \\
\hline 18 & Uganda & Indonesia & Mozambique & Nigeria \\
\hline 19 & Tunisia & Sudan & Peru & Kyrgyzstan \\
\hline 20 & Ivory Coast & Ethiopia & Bangladesh & Kazakhstan \\
\hline & & & Source: AidData 3.1 (Tierney et al. 2011) &
\end{tabular}

OECD DAC donors have a unique pattern of democracy aid allocation compared to general foreign aid allocation. The most significant thing is that U.S. top recipients are also ranked top recipients of all OECD DAC donors. The top five recipients of U.S. 
democracy aid, such as Iraq, Afghanistan, Egypt, and Pakistan, are among the top five democracy aid recipients of OECD DAC donors. This is because the U.S. is the most prominent democracy aid donor for several decades and provided around 40 percent of democracy aid. Second, most of the significant democracy aid recipient are authoritarian regimes. Third, OECD DAC donors have different democracy aid allocation patterns than overall foreign aid allocation. The top three recipients of foreign aid of OECD DAC donors are relatively smaller volumes of democracy aid. China and Indonesia, which are the top two recipients of overall foreign aid from all OECD DAC donors, are ranked the fifteenth and eighteenth in democracy aid. Russia, the third-largest recipient of foreign aid, is out of the top 20 recipients of democracy aid.

The top recipients of U.S. foreign aid show more unique U.S. aid allocation patterns between 1990 and 2013. First of all, recipients of U.S. foreign aid reflect U.S. security interests. Among 20 countries, 11 countries can be considered the 'client' state of the U.S that support U.S. policies in exchange for economic or security benefits (Sylvan \& Majeski 2009). Also, the top two recipients, Iraq and Afghanistan, are the countries that the U.S. that had military interventions during the period. It implies that the U.S. used foreign aid to settle the conflicts and rebuild the country after the wars. Egypt is also ranked one of the top recipients of U.S. foreign aid because of the security interests of the U.S. The U.S. also provided foreign aid to Egypt to sustain the 1979 Egyptian-Israeli peace treaty (Sharp 2020). Also, most top recipients such as Pakistan, Indonesia, Jordan, Colombia, and Turkey are core states in the region for the U.S. security or economic interests in the area. 
The top recipient of U.S. democracy aid is similar to overall U.S. foreign aid. Iraq, Afghanistan, Egypt, are Pakistan are the top recipients of democracy aid. It implies that the U.S. has a similar strategic approach to democracy aid with overall foreign aid. It means that democracy promotion is not the only concern of the U.S. when they allocate democracy aid. The U.S. is more likely to use democracy promotion as an intermediate goal for the security or economic interests of the U.S. Second, the former Soviet republics had relatively large democracy aid from the U.S. Armenia, Georgia, Ukraine, Kyrgyzstan, and Kazakhstan are ranked top 20 recipients of democracy aid. It implies that the U.S. tried to support newly independent countries after the end of Cold War.

\section{Recipient Regime Types and U.S. Democracy Aid}

Recipient countries have different institutional foundations and sociopolitical conditions. Particularly, there is considerable variance between authoritarian regimes. Many scholars argue that different types of authoritarian regimes depend on their institutional background and maintaining power mechanisms (Geddes, Wright \& Frantz 2014, Wahman, Teorell \& Hadenius 2013, Cheibub, Gandhi \& Vreeland 2010). Each type of authoritarian regime has unique characteristics. Some of them already adopted democratic institutions, and some of them maintain their power severe repression mechanism.

Therefore, donors are necessary to have a different approach to authoritarian regimes to achieve the goals of democracy aid. The volume of democracy aid is essential, but also donors need to provide proper programs to maximize its effect. Donors have to calibrate the sociopolitical conditions of recipient countries and decide right democracy aid programs. Therefore, donors are more likely to change the composition of democracy aid 
depending on the recipient.

Figure 1.10 shows how the U.S. formulates democracy aid programs depending on authoritarian regime types between 1990 and 2013. Based on the Wahman, Teorell \& Hadenius (2013) authoritarian regimes typology (hereafter THW), I calculate the share of each program of democracy aid. THW categorizes authoritarian regimes into four different types based on survival mechanisms and institutional characteristics: multi-party, one-party, military, and monarchy.

Figure 1.10 describes that the U.S. has provided different democracy aid programs by authoritarian regime types. First, although it only shows aggregated democracy aid allocation patterns, each type of authoritarian regime shows unique patterns in the composition of democracy aid. For instance, democracy aid to multi-party regimes is consists of around 55 percent of governance, 28 percent of judiciary, and 12 percent of civil society programs. However, democracy aid to one-party regimes had approximately 30 percent of governance, 30 percent of civil society, and 15 percent of human right programs. Thus, the U.S. has a distinct approach by authoritarian regime types in shaping democracy aid programs.

Second, the most extensive program in most authoritarian regime types is governance. It is an inevitable consequence because governance is the most extensive program. The share of governance programs of the U.S. was 53.5 percent in this period. However, the ratio is quite different by regime types. For example, monarchies have around 95 percent of democracy aid with governance programs, but the percentage of governance programs to one-party is about 30 percent. 


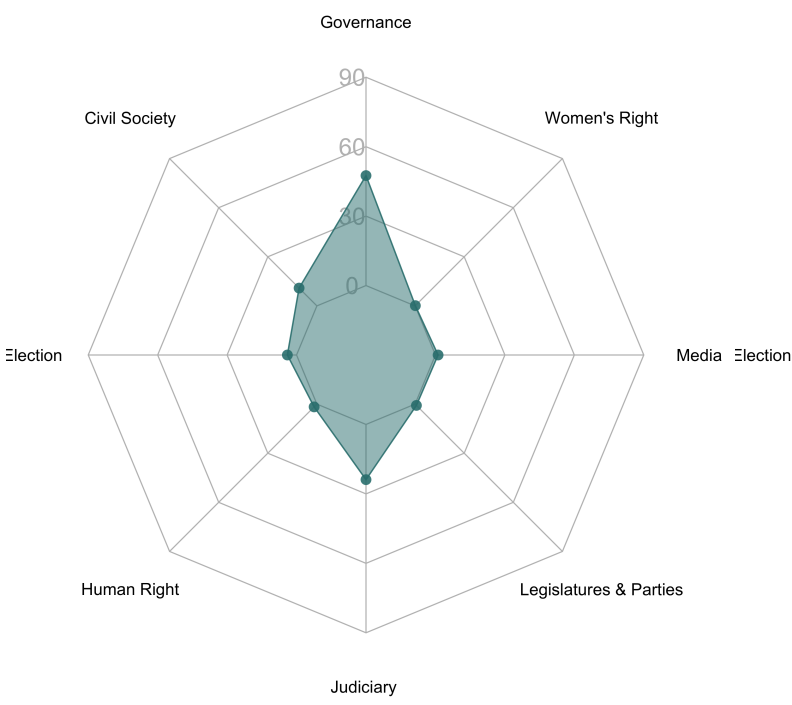

(a) Multi-party

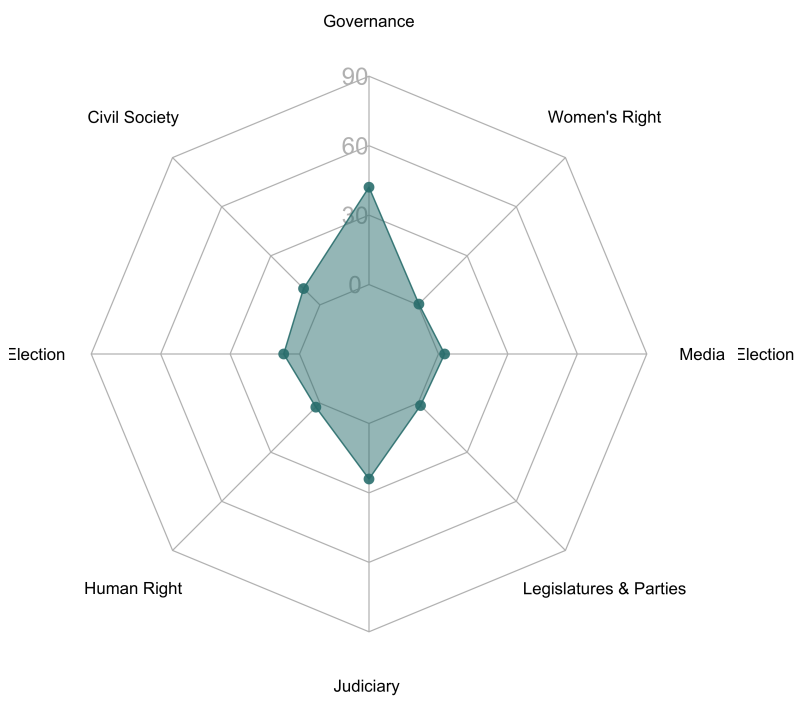

(c) Military

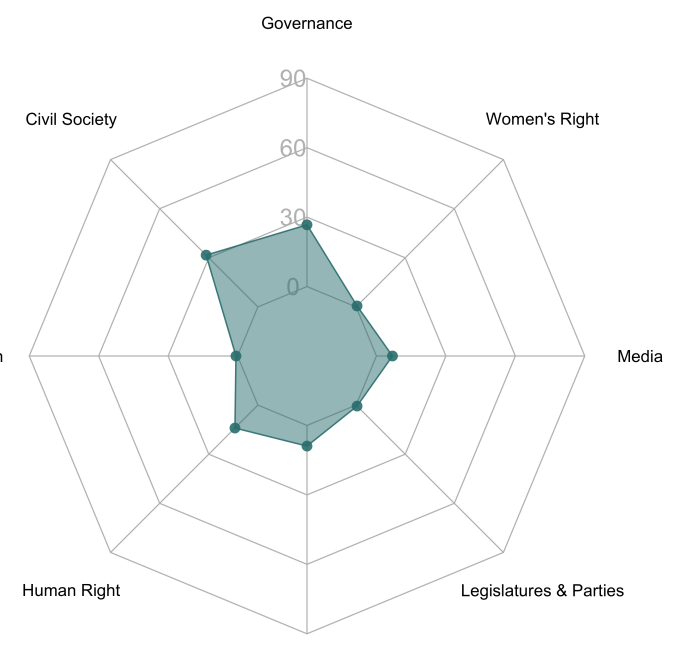

Judiciary

(b) One-party

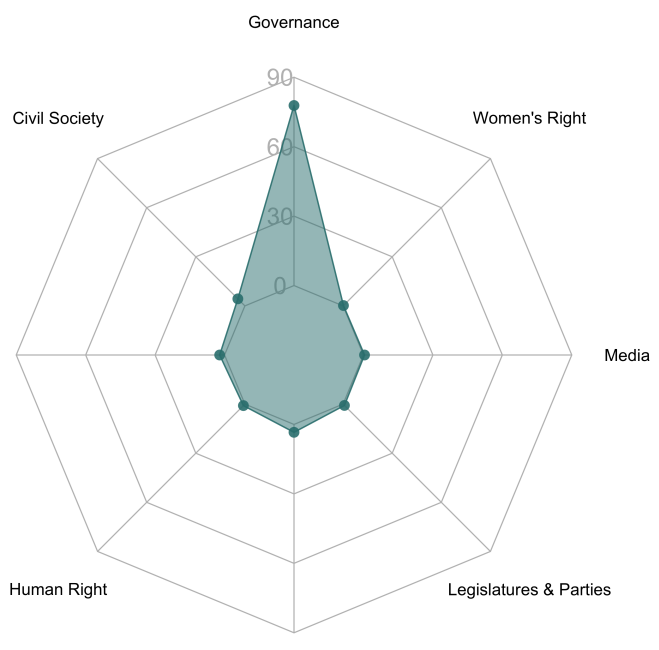

Judiciary

(d) Monarchy

Figure 1.10: Democracy Aid by Authoritarian Regime Types (1990-2013)

Source: AidData 3.1 (Tierney et al. 2011) 


\subsection{Organization of the Dissertation}

This dissertation has three substantive chapters. Chapter 2 introduces a theoretical argument on democracy aid allocation mechanisms between donors and recipient countries. Chapter 3 explores how donors make strategical decisions about democracy aid allocation, while chapter 4 examines the recipient government influence over democracy aid allocation.

In Chapter 2, based on three assumptions, I discuss the two types of democracy aid—regime-compatible democracy aid and regime-incompatible democracy aid—and assess whether certain democracy aid programs threaten authoritarian leadership in recipient countries. Considering political conditions within authoritarian regimes, authoritarian leaders view democracy aid programs differently, measuring whether the aid would threaten them or provide a valuable opportunity. My main argument is twofold. The first part considers donor motivations and strategic choices when distributing democracy aid. Two motivations - a normative commitment toward democracy and security or economic self-interest—cause donors to prefer different types of democracy aid. Donors provide more regime-compatible democracy aid to an authoritarian regime if the latter is important for the donors' security or economic interests.

The second part of my argument concerns the recipients. Scholars argue that authoritarian regimes have various political institutions and survival mechanisms in place to keep them in power. Based on their arguments, I discuss the distinct preferences of four types of authoritarian regimes toward eight different subtypes of democracy aid. My main argument is that recipients do not blindly accept all forms of democracy aid and have the 
ability to affect democracy aid composition using their leverage over donor countries.

Chapter 3 examines donors' strategic choices during democracy aid allocation using the U.S. democracy aid data between 1990 to 2013. First, I operationalize donors' security and economic interests using various proxies and defined donor relations. Then, I test the hypothesis of whether donors-recipient relationships affects democracy aid allocation patterns. The empirical results support my theory that donors provide more regimecompatible democracy aid to authoritarian regimes if they are in clientelistic relationships with the United States. These findings imply that donor self-interest can distort democracy aid causing it to be less effective at promoting democracy.

Following from the previous chapter, Chapter 4 tests recipient influence over democracy aid allocation. Here I test whether authoritarian regimes can acquire more regimecompatible democracy aid, while reducing regime-incompatible democracy aid, when facing greater challenges to their political survival. Authoritarian governments in recipient countries can have different leverage over the donors in democracy aid allocation processes depending on their relationship with donors. For example, donor countries are generally less willing to break down or destabilize their clientelistic authoritarian regimes which are critical for donor nation security or economic interests. The empirical findings from the U.S. democracy aid allocation patterns support my arguments. A recipient country with a clientelistic relationship with the U.S. receives more regime-compatible democracy aid when they confront domestic challenges. On the other hand, the U.S. reduces regime-compatible democracy aid to non-clientelistic authoritarian regimes when they face similar domestic challenges. 
In this dissertation, I provide insight on democracy aid allocation when recipients are ambivalent about accepting such aid. A conventional assumption about foreign aid is that recipients are always willing to accept it. Recipient countries, however, are not always willing to accept foreign aid, due to various domestic conditions. My theoretical argument explains how democracy aid allocation patterns are affected by the self-interests of both donors and recipients.

My research is, however, necessarily limited. The concept of 'regime compatibility' discussed in this project needs further fleshing out. I apply Wahman, Teorell \& Hadenius (2013) authoritarian regime typology, but I concede that it an imperfect tool for figuring out the institutional differences between regimes. I also discuss the limitation of operationalization on donor-recipient relations. This is the most critical reason that I focus on U.S. democracy aid in the empirical chapters. Although democracy aid is a dynamic process between donors and recipient countries, there is no common measurement to measure a dynamic relationship between two countries.

This study is important because it provides new insight on the effectiveness of democracy aid. A conventional question about democracy aid is whether democracy aid an effective tool for promoting democracy. Previous foreign aid studies focus on the quantity of aid allocation when they evaluate aid's effectiveness. However, my argument provides new insight into how foreign aid quality is affected by the self-interest of both donors and recipients. Moreover, another importance of this study is that it provides a theoretical framework for analyzing foreign aid allocation—sometimes recipient countries perceive foreign aid as an opportunity and sometimes as a threat to their domestic politics. In recent 
years, recipient countries have not accepted foreign aid from Western donors. Recipient governments also try to enact regulations on foreign funding to domestic NGOs (Dupuy, Ron \& Prakash 2015, Hailegebriel 2010). These cases indicate that recipients have a specific preference for foreign aid and want to reduce the impact of foreign aid on domestic politics. Therefore, my argument has implications for explaining the divergent patterns in democracy aid allocation and provides insight into democracy aid effectiveness. 


\section{Chapter 2}

\section{Distribution Mechanisms of Foreign Aid}

Foreign aid allocation is an interactive process between donor and recipient governments. Donor governments decide how much they deliver to a country for a particular purpose, and recipient governments decide whether to accept a foreign aid package. The majority of foreign aid literature understands foreign aid allocation to be a donor-driven process. This view, however, overlooks the role of recipient government preferences during these negotiations. Indeed, extant literature on foreign aid allocation assumes that recipient countries are passive actors in the allocation process, and willing to accept all types of aid because it is an extra resource for the government budget and economic development.

I add to this discussion by arguing that recipient government preferences do matter in the eventual distribution of foreign aid. In this section, I develop a theoretical argument on how donors allocate foreign aid and when donors take recipient' preferences into account. Aid allocation is a strategic interaction between donors and recipient countries (Swedlund 2017). Although donors mainly provide foreign aid for their motivations (Alesina \& Dollar 2000, Neumayer 2003b, Bueno de Mesquita \& Smith 2009, Younas 2008), both donor interests and recipient preferences play important roles in aid allocation. The preferences of recipient governments can influence foreign aid allocation in that 
these governments may reject aid if the cost of accepting greater than the benefits they anticipate receiving.

For recipient countries, all aid dollars are not equal. Donors provide various types of foreign aid targeting different objectives through diverse delivery channels. Examples include aid for political, civil, and economic development. Donors deliver aid through various channels, such as their own agencies and nongovernmental organizations (NGOs) as well as direct to recipient governments (Dietrich 2013, Acht, Mahmoud \& Thiele 2015, Baldwin \& Winters 2020). Recipient governments have different preferences for the various types of aid, and on the delivery mechanisms used to provide it, because these factors can impose different political or social costs.

Democracy aid and bypass aid are two types of foreign aid over which recipient regimes are likely to possess strong preferences. Democracy aid and bypass aid can endanger authoritarian regimes. However, donors have been delivering these types of aid for decades to authoritarian regimes. Why have authoritarian governments accepted these types? And what is the consequence of accepting these types of foreign aid? In this chapter, I develop theoretical arguments to answer these questions.

\subsection{Willingness, Constraints, Opportunities, and Threats}

Scholarship on foreign aid allocation suggests that the motivation of a donor country is the most important factor in aid allocation. The conventional wisdom among scholars is that donors mainly provide aid to achieve their own strategic or economic interests (Alesina \& Dollar 2000, Neumayer 2003a, Bueno de Mesquita \& Smith 2009, Stone 2004, Dreher, Nunnenkamp \& Thiele 2008). Although donors do consider recipient country needs or 
characteristics (Winters \& Martinez 2015, de la Croix \& Delavallade 2014, Alesina \& Dollar 2000), their assessment ultimately reflects donor preferences. Therefore, the aid allocation process is mainly donors' decision. This perspective assumes that foreign aid is essentially an extra fungible resource for recipient countries, so there is no reason for recipients not to accept it and put it to use achieving their development needs (Morrison 2009, Ahmed 2012).

Recipient countries, however, are not willing to blindly accept all aid dollars. Recipient countries have a preference for foreign aid packages depending on their political, social, or economic conditions. Recipient governments refuse foreign donors' aid offers because they do not want to have aid which can disturb their domestic stability (Carothers 2006). For instance, Rodrigo Duterte rejected a 280 million dollar foreign aid package from the European Union (EU) in 2017 that came with the condition that Duterte enforces human rights regulations. ${ }^{1}$ Duterte blocked off the aid flow, which he considered ruinous to the legitimacy of his presidency. The case of the Philippines shows that recipient governments are important players in aid allocation process and their preference may affect the aid allocation patterns of donors.

My theory of aid allocation is based on three core assumptions. The first assumption is that foreign aid is a way for donor countries to extend their political influence in recipient countries. Foreign aid increases the linkage of foreign donors and makes recipient governments more susceptible to international influence (Levitsky \& Way 2006). The more linkage helps donors exert more political pressure to make recipient countries

\footnotetext{
${ }^{1}$ Chithra Purushothaman, "Why Is the Philippines Adapting Away Foreign Aid." May 25, 2017. https: //thediplomat.com/2017/05/why-is-the-philippines-turning-away-foreign-aid (Retrieved: 6.25.2021).
} 
change policies, institutions, or norms to meet international standards from the donors' perspective. Foreign aid can influence domestic politics in recipient countries themselves. Although foreign aid provides extra revenues, foreign aid can threaten incumbents in recipient countries. High dependency on foreign aid may decrease the quality of government of recipients (Knack 1999). Similarly, rapid decreases of foreign aid may increase conflict in recipient countries (Nielsen et al. 2011). Particularly, foreign aid from the Western donors can endanger the survival of authoritarian regimes in recipient countries in that it stimulates democratization (Knack 2004, Dunning 2004, Finkel, PérezLiñán \& Seligson 2007, Bermeo 2011). Finkel, Pérez-Liñán \& Seligson (2007) suggests that foreign aid can promote democracy in both direct and indirect ways: reforming some structural conditions and supporting oppositions groups in the domestic. Knack (2004) also argues that foreign aid can promote democratization through providing technical assistance to democratic institutions, attaching conditionality, and improving education and economic development.

Which forms of aid packages might be considered inferior goods by recipient governments in authoritarian regimes? In general, authoritarian leaders in recipient countries tend to disfavor foreign aid packages with harsh conditionality. Traditionally, the Western donors have attached various conditions on foreign aid packages (Bräutigam 2009). Donors impose conditionality based on their own standards and may be aggressive and burdensome to recipient governments. Leaders in recipient countries are more likely to reject foreign aid if the conditionality can destabilize their regime. Secondly, authoritarian regimes are also like to view democracy aid as an inferior good. Democracy aid 
aims to assist democratic transitions and break down incumbent authoritarian regimes. Democracy aid can threaten the political survival of authoritarian leaders, and they may consider democracy aid as an inferior good. Finally, a delivery channel is a matter to recipient countries. Recipient governments prefer government-to-government, bilateral aid and are more likely to disfavor bypass aid regarding the aid delivery channel. This is because bypass aid is less fungible, and it is hard to appropriate for their political purpose. Furthermore, bypass aid can strengthen civil society and foment political resistance to authoritarian regimes.

The second assumption of the research is that the primary goal of leaders in recipient countries is political survival (Bueno de Mesquita \& Smith 2009). Political leaders seek to maximize their tenure in the power. All political decisions of leaders are made with their survival in mind. Regarding foreign aid, leaders make decisions on whether to accept aid depending on whether it will affect leaders' political survival. Leaders in authoritarian regimes are especially sensitive to their survival. Compared to democratic leaders, authoritarian leaders have low political legitimacy so that they are exposed to both international and domestic threats. Furthermore, leaders in authoritarian regimes typically face exile, imprisonment, or death after stepping down from power (Geddes, Wright \& Frantz 2014, Goemans 2008). Therefore, when leaders in authoritarian regimes perceive a threat to their survival, they fervently work to block and minimize it.

The third assumption is that recipient governments are active in the foreign aid allocation process. The conventional wisdom is that foreign aid allocation is under donors' complete control. Donors' willingness for providing foreign aid is a key factor of aid 
allocation. However, recipient governments have preferences on foreign aid and make decisions on whether to accept foreign aid depending on how it may affect their prospects for political survival. Therefore, I view the aid allocation process as a negotiation between donors and recipient countries on foreign aid packages to maximize their interest (Swedlund 2017).

Figure 2.1 and 2.2 describe foreign aid allocation mechanism from donors to recipient countries. In Figure 2.1, a primary decision maker of foreign aid is donor government. Donor governments create foreign aid packages based on their interests or motivations. The decide recipient countries, volume of aid, and types of aid. Also, donor governments make a decision on the delivery mechanism. They select object of distributions who deliver foreign aid to targets. Donors have different options, and they can be categorized two mechanisms: Aid to recipient government and aid to recipient non-governmental sectors. However, recipient governments can have influence on donors' decisions on aid packages and delivery mechanisms based on their leverage on donors. If donors have more interests on recipient country, recipient government can exert more influence on the donors' decision-making process to provide more regime favorable foreign to them. Figure 2.1 describes this interactive process between donors and recipient countries on foreign aid allocation.

Alternatively, in Figure 2.2, I describe the aid allocation process with a decision tree model to show an interactive aid allocation process between donors and recipient countries. Once donors offer foreign aid to a recipient country, the recipient government decides whether they accept foreign aid considering the terms of aid and their domestic 
conditions. Recipient governments accept foreign aid if they assess the cost of aid offer is smaller than the benefits. However, if the recipient government does not accept foreign aid, donors may provide another offer to make the recipient government accept it or withdraw their aid offer. Once recipient decide to accept foreign aid, donors can select an aid channel between aid to the government and aid to NGOs (bypass aid). The recipient government is always willing to accept aid to the government because it can increase extra revenue. However, the recipient government may not allow aid to the non-governmental organizations directly if donor governments perceive threats from the aid bypassing the government. In each stage of decision-making node, donor and recipient governments depending on their interests and leverages to each other.

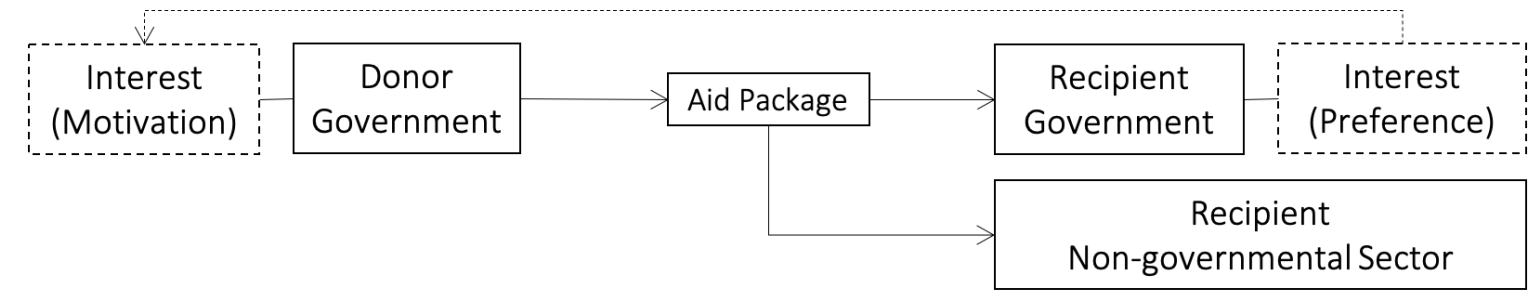

Figure 2.1: Delivery Mechanism of Foreign Assistance

Based on these assumptions, I argue that an aid allocation process is a strategic interaction between donor and recipient countries. Aid distribution from donors to recipient countries is the result of a bargaining process between donors and recipient countries. Therefore, the preferences and interests of both donors and recipient countries are important determinants of the composition of aid packages. If leaders in recipient countries view aid packages as a threat, rather than as a source of fungible resources, then may reject the aid package and aid allocation will not occur. Recipient countries can block 
certain forms of foreign aid inflow to their country to minimize a negative impact from foreign aid. Therefore, the flip side of recipient preference on foreign aid is the constraints of donors' aid allocation strategy. Although donors have willingness to provide aid, the preference of a recipient government can constraints it.

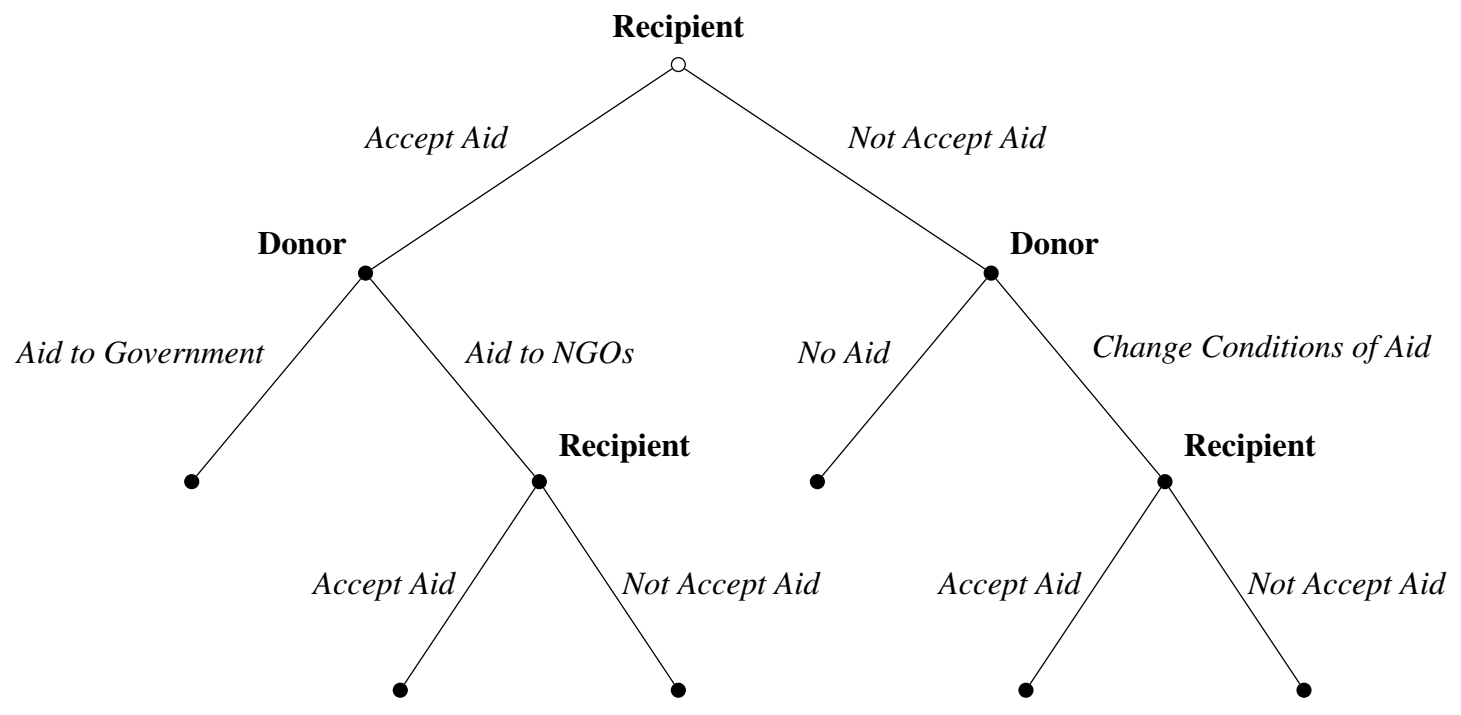

Figure 2.2: Delivery Mechanism of Foreign Assistance

These two foreign aid forms can be considered inferior goods to recipient authoritarian governments: democracy aid and bypass aid. Democracy aid is intended to support a democratic transition in authoritarian regimes. Democracy aid targets enhancing democratic institutions, practices, and norms in authoritarian regimes. They enforce political challenges of authoritarian leaders and social movements for democracy so that authoritarian leaders can perceive democracy aid as an external threat to the political survival of authoritarian regimes.

Authoritarian leaders also are not willing to have bypass aid. If donors bypass the re- 
cipient governments and deliver aid to multilateral organizations or NGOs in civil society directly, it reduces the fungible aid to the recipient government. Authoritarian leaders in recipient countries lose revenue for their budget and money for maintaining a winning coalition. Furthermore, increasing bypass aid can stimulate popular demand for democratic reforms by strengthening civil society. External funds for Local NGOs and private sectors increase civil society's capacity, but donors can select beneficiary based on their strategical goals.

In my dissertation, I focus on the democracy aid allocation patterns. I discuss the donors' motivations for democracy aid and how donors make strategic choices on democracy aid types. Also, I argue how authoritarian regimes have different preferences on democracy aid types by domestic situations and explain how authoritarian governments can reflect their preference on democracy aid.

\subsection{Donors' Interests on Democracy Aid}

Why do donors want to provide democracy aid? In this section, I explain donors' motivations for providing democracy aid to authoritarian regimes. Also, I discuss how donors provide democracy aid to authoritarian regimes to maximize their interests. Since the end of the Cold War, donors have increased the volume of democracy aid to promote democratization and democratic consolidation in recipient countries (Carothers 2000). Winning the Cold War gave Western democratic donors more confidence in the superiority of democracy and motivated donors to provide more democracy aid to authoritarian regimes and new democracies. Western donors also want to promote democracy in authoritarian regimes for security and economic reasons. 


\subsubsection{Why Do Donors Want to Provide Democracy Aid?}

Western donors have complex motivations for providing democracy aid (Wolff \& Spanger 2017). On the one hand, democracy aid reflects Western donors' normative commitment to democracy. Promoting democracy has been one of the core foreign policy goals for most prominent donors of foreign assistance. They naturally believe that democratic government is the superior political system. This is a fundamental foundation of democracy promotion and motivation for providing democracy aid. Democracy efficiently and effectively represents their peoples' interests. It also protects human rights, and individual freedoms (Stier 2014, Møller \& Skaaning 2013). The economic success of Western donors reinforces their confidence in democracy.

The conclusion of the Cold War buoyed Western nations' confidence in their own systems of government. The collapse of the Soviet Union signaled to major Western nations the victory of liberal capitalism against Communism, and democracy against authoritarianism. Although foreign aid programs had unique nominal goals during the Cold War, donors prioritized strategic considerations over altruistic aid goals because of the global security environment. Donors utilized foreign aid as a tool for bolstering client states and containing the spread of Communism. However, the end of the Cold War provided Western donors room to seek more idealistic goals. Western donors have subsequently increased the volume of democracy aid since the 1990s (Carothers 2000).

On the other hand, modern promotion of democracy is certainly not a purely altruistic goal on the part of donors. Western donors provide foreign aid for reasons other than their normative commitment to democracy. They also provide democracy aid to support their 
security and/or economic interests (Alesina \& Dollar 2000, Neumayer 2003a, Bueno de Mesquita \& Smith 2009). They are more likely to consider specifically promoting democracy as an intermediate goal among other foreign policy goals (Maoz \& Russett 1993). In some cases, donors provide democracy aid to bolster regimes that support specific foreign policies. Donors may give aid to recipient countries in exchange for access to natural resources (Kapfer, Nielsen \& Nielson 2007), mutual trades (Younas 2008, Barthel et al. 2014), vote buying in international organizations (Dreher, Nunnenkamp \& Thiele 2008, Kuziemko \& Werker 2006, Hoeffler \& Outram 2011), and counter-terrorism (Bapat 2011a, Boutton \& Carter 2014). Donors also provide more aid to their trade partners in hopes of boosting economic activity.

In other cases, donors provide democracy aid with the broader purpose of increasing the prevalence of regimes that share its values and that may have more peaceful and capitalist ambitions in world politics. According to the Democratic Peace Theory, democratic countries are less likely to initiate conflict with other countries. Donors are so incentivized to support the effort for democratic transition in authoritarian regimes (Russett et al. 1995, Maoz \& Russett 1993, Bueno de Mesquita et al. 2014). Scholars argue that institutional characteristics and the political culture of democracy make countries are more peaceful (Russett 1993, Fearon 1994, Reiter \& Tillman 2002, Risse-Kappen 1995). Democratic institutions such as elected leaders and the separation of powers impose more audience costs to political leaders and thus restrain democracies from going to war (Fearon 1994, Reiter \& Tillman 2002). The normative explanation argues that democratic norms value resolving a conflict by nonviolent means (Dixon \& Senese 2002, Kahl 1998). 
Therefore, democracy aid has the potential to reduce security threats from the third world and reduce policy efforts to maintain the stability of the region and international system in the long-term.

Donors thus have different motivations for providing democracy aid-they do so sometimes to promote democracy as a normative good and sometimes preference instead their security or economic self-interest. Democracy aid, therefore, often looks different when extended to different recipient countries. Democracy aid may be more effective at promoting democracy if donors are more oriented toward normative goals of democracy promotion. If donors provide democracy aid based on security concerns or strategical goals, they may deliver democracy aid according to security concerns instead.

\subsubsection{Donors' Strategic Choice on Democracy Aid}

After the end of the Cold War, although a new global security environment allowed donors to pursue democracy promotion more actively, security and/or economic interests are still their primary goals (Remmer 1998, Milner \& Kubota 2005). Because of the lower priority of democracy promotion, donors may not provide democracy aid only for democracy promotion in all recipient countries. Instead, they are more likely to design democracy aid in accordance with their security and/or economic interests.

Donors provide different democracy aid to authoritarian regimes depending on the donors' security or economic interests in authoritarian regimes. If an authoritarian regime serves donor interests, the donor wants to maintain a good relationship with the supportive authoritarian regime. The donor may not favor the democratic transition of the authoritarian regimes because the donor has no idea whether a new democratic government will 
support them as well. In these situations, maintaining the status quo is the best policy for the donor. The donor is more likely to provide democracy aid in the way to support the incumbent authoritarian regime. Therefore, when authoritarian regimes serve donor interests, the characteristics of democracy aid to the authoritarian regimes are more likely to serve as external support for those in power

However, if donors do not have security or economic interests in the recipient countries, donors are more likely to provide democracy aid that is more suitable for promoting democracy. Promoting democracy in these recipient countries does not conflict with donor interests. Moreover, donors are more than willing to use democracy aid to undermine less-friendly regimes. Although there is blame on democracy aid in that donors use democracy promotion to justify self-interest-seeking acts, donors can have a strategic choice on democracy aid allocation.

Donors have delivered various types of democracy aid to recipient countries targeting different sociopolitical dimensions for promoting democracy. Donors are likely to strategically target these different types of democratic institutions in authoritarian regimes depending on whether they want to assist or weaken the regime. Some types of democracy aid, such as aid for enhancing the governance system, is necessary for democracy promotion, but can also help the current authoritarian regimes maintain their political power. As in Jordan's case, donors can support an authoritarian regime under the name of democracy aid. Furthermore, some forms of democracy aid are not effective in promoting democracy in some authoritarian regimes because of their institutional or social conditions. There is a significant variance in authoritarian regimes, and some authoritarian regimes adopt 
democratic institutions in their regimes even if they do not function as ones in democracies (Geddes, Wright \& Frantz 2014, Magaloni, Chu \& Min 2013). Authoritarian regimes also have different regime stability. It means that authoritarian regimes have distinct political capacity on democracy aid. Therefore, there is room for donors' strategic choice on democracy aid depending on the security or economic interests.

The strategic considerations of donors decide whether the donor will offer regimecompatible democracy aid or regime-incompatible democracy aid to authoritarian regimes. I define regime-compatible democracy aid to be aid that supports a specific institutional characteristic of an authoritarian regime, and regime-incompatible democracy aid as that which undermines the institutional traits of a regime. ${ }^{2}$. Regime-compatible democracy aid has similar characteristics with an extra resource to authoritarian regimes while authoritarian regimes perceive regime-incompatible democracy aid as a threat to their political survival. Donors make a strategic choice between regime-compatible democracy aid and regime-incompatible democracy aid in accordance with their interests in recipient countries.

Table 2.1 describes how donors provide democracy aid to recipient countries depending on their strategic consideration in recipient regimes. Donors establish a different relationship with recipient countries depending on their strategic goals in recipient countries. I define three types of strategic relationship between donors and recipient regimes: $p a$ tronage, neutral, and antagonistic relationships. Donors establish a clientelistic relationship with a recipient country if the recipient country has higher security and/or economic

\footnotetext{
${ }^{2}$ You can find more details on which types of democracy aid is whether regime-compatible or regimeincompatible depending on regime types on Table 2.2.
} 
interests of donors, and incumbent regimes are cooperative with the donor. If recipient countries are non-cooperative with donors on foreign policy matters, donors have an antagonistic relationship with recipient regimes. Finally, donors have a neutral relationship with recipient countries if donors have low economic or security interests in recipient regimes.

Table 2.1: Donors' Interests and Volume of Democracy Aid

\begin{tabular}{clll}
\hline \multirow{2}{*}{ Types } & \multicolumn{3}{c}{ Donor-Recipient Relationship } \\
\cline { 2 - 4 } & Clientelistic & Neutral & Antagonistic \\
\hline Democracy Aid & Large & Small & Small \\
regime-compatible & Large & Medium & Small \\
regime-incompatible & Small & Small & Medium \\
\hline
\end{tabular}

First, to authoritarian regimes in a clientelistic relationship, donors provide a large amount of regime-compatible democracy aid. Donors want to provide democracy aid to support these authoritarian regimes. They also want to use democracy aid as a foreign policy tool to have more policy concessions for their security or economic interests from recipient countries. Therefore, donors want to provide a large amount of regime-compatible democracy and a small amount of regime-incompatible democracy aid to client states.

Second, donors may have an aggressive policy on democracy aid toward recipient countries with whom they have antagonistic relationships. Donors want to destabilize or break down the incumbent regimes in these recipient countries because incumbents are not cooperative or are otherwise hostile. Therefore, donors provide relatively large regime-incompatible democracy aid to the authoritarian regime to promote democratic transition or political instability. Donors may bring normative goals of democracy aid to 
the fore and may be more likely to support vulnerable aspects of authoritarian regimes. However, the volume of regime-incompatible democracy aid cannot be large because authoritarian regimes can deny accepting democracy aid if donors target political survival through regime-incompatible democracy aid. Therefore, in these situations, donors provide relatively more regime-incompatible democracy aid compared to regime-compatible democracy aid to these countries, but the total amount of democracy aid could not be large compared to the client states.

Finally, donors provide a relatively small amount of democracy aid to authoritarian regimes with whom they have neural relationships. Donors might have low security or economic interests in these countries, but they may prefer to maintain the status quo. This policy goal makes donors provide a small volume of democracy aid and a small ratio of regime-incompatible democracy aid so as not to hurt the current relationship.

According to this logic, I derived a testable hypothesis:

Hypothesis 1 Donors are more likely to provide more regime-compatible democracy aid to supportive authoritarian regimes.

\subsection{Recipients' Preference on Democracy Aid}

Authoritarian leaders face various threats from inside and outside of their borders because of their “original sin” (Gandhi \& Przeworski 2007, Przeworski 1986, Donno 2013). Generally, they come to the power without popular consent, and this exposes them to more threats to their political survival than leaders in democracies. If authoritarian regimes cannot prevent the threats effectively, they move lose power or become unstable. There are 
two types of threats to authoritarian leaders. First, from inside their border, they are faced with threats from either the ruling elites within their party or from a more popular alternative party (Gandhi \& Przeworski 2007). Authoritarian leaders inevitably share their power with a narrow ruling elite, and challenges can arise from within this class. For example, unsatisfied military leaders can conduct a coup d'état. Authoritarian leaders are also exposed to threats from the bottom. They are anxious about the threat of democratic revolution and social unrest among the mass public. Therefore, authoritarian leaders try to provide spoils to the ruling party and wining coalition groups but also purge the prominent challengers and repress civil movement toward democratization.

Second, external factors are another type of threat to the political survival of authoritarian leaders. Wars against other countries or military interventions by an external power is a direct threat to the regime survival. Foreign support of the opposition, dissidents, or civil society also can be a direct threat to incumbent authoritarian leaders. Foreign supports increase capacity of opposition groups and reinforce the internal threats in the regime. Moreover, indirect external influence can be a threat to authoritarian leaders. Diffusion or promotion of democratic norms can stimulate anti-government movements or democratic movements in authoritarian regimes.

From the authoritarian leader's perspective, foreign aid is an opportunity. As a nontax revenue, foreign aid is similar to a natural resource, such as oil. Foreign aid can help an authoritarian leader increase social spending and distribute more resources for economic development (Djankov, Montalvo \& Reynal-Querol 2008, Ahmed 2012, Kono, Montinola \& Verbon 2015). This reduces the probability of coup d'état and revolutions 
in non-democratic undeveloped countries (Acemoglu \& Robinson 2001, Houle 2015). Furthermore, authoritarian leaders can appropriate foreign aid for bribes or private goods for the winning coalition—which is a group of supports to maintain power (Bueno de Mesquita \& Smith 2009).

Foreign aid, however, can pose a significant threat to the political survival of authoritarian leaders. Although donors can have extra resources from foreign aid, it is a type of external intervention in domestic affairs. Accepting foreign aid also makes recipient countries are more vulnerable to external influence (Levitsky \& Way 2006). Donors can use the dependency of recipients on foreign aid as leverage for their political intervention. Once recipient countries depend on foreign aid for their budget, foreign aid volatility can increase political conflict in recipient countries (Nielsen et al. 2011, Gutting \& Steinwand 2015). Moreover, foreign aid can undermind legitimacy of a recipient government (Baldwin \& Winters 2020, Blair \& Roessler 2018). According to the fiscal contract theory, foreign-funded public service provision can undermine citizens' perception of government accountability and legitimacy (Baldwin \& Winters 2020). Therefore, authoritarian regimes may consider foreign aid as a threat to their political survival.

The question remains: when do authoritarian regimes consider foreign aid an opportunity versus a threat to their regime? My argument on this question is that authoritarian leaders in recipient countries have different perceptions (preferences) on foreign aid depending on domestic political conditions. Authoritarian leaders come into power with different pathways such as coups, manipulated elections, or elections after coups. They also establish different political institutions for maintaining power and legitimacy. These con- 
ditions make each authoritarian leader-whose primary goal is political survival—have a different perception on foreign aid between an opportunity and a threat. Furthermore, foreign aid consists of different projects or programs. Particularly, democracy aid consists of different subtypes, which targeting various dimensions of democracy. Authoritarian leaders may have different acceptability on various projects of democracy aid depending on their political condition.

\subsubsection{Authoritarian Regimes and Democracy Aid Regime Compatibil- ity}

There are numerous varieties of authoritarian regimes (Geddes 1999b). Each authoritarian regime has distinctive characteristics. Authoritarian leaders have different pathways for attaining and maintaining power, and a unique institutional background. For instance, authoritarian leaders come to power by hereditary succession, military coups (e.g. Augusto Pinochet of Chile), regular multiparty elections (Ilham Aliyev of Azerbaijan), or even elections after military coup (Park Chung Hee of South Korea). To secure their political survival, some authoritarian regimes go beyond economic and political corruption and coopt adopt democratic institutions such as political party or legislatures in their regimes (Gandhi \& Lust-Okar 2009, Gandhi \& Przeworski 2007, Bunce \& Wolchik 2010, Knutsen, Nygård \& Wig 2017).

Scholars find that there is 'gray area' between full-democracy and full autocracy (Levitsky \& Way 2010b, Epstein et al. 2006, Schedler 2002b, Diamond 2002). With the different institutional foundations, authoritarian regimes have divergent political stability and perception on internal and external threats. Also, they have different political strate- 
gies and institutional apparatus such as coup-proofing, social repressions, media control, or prohibition of political activity depending on their political conditions. previous studies find that some authoritarian regimes have distinctive characteristics in regimes stability (Geddes 1999a, Brownlee 2009), economic development (Charron \& Lapuente 2011), and level of social repressions (Davenport 2007a, Davenport 2007b).

Several scholars classify authoritarian regimes into distinct subtypes based on institutions, leadership types, or power-sharing mechanism (Geddes, Wright \& Frantz 2014, Wahman, Teorell \& Hadenius 2013, Cheibub, Gandhi \& Vreeland 2010, Magaloni, Chu \& Min 2013). ${ }^{3}$ Although these typologies are not exclusive and there is no universal definition of authoritarian regime types, each typology reveals distinct characteristics in institutions and survival mechanism. Types of authoritarian regimes reflects institutional constrains and capacity for addressing threats. It makes authoritarian leaders have different perception on internal and external threats. Also, authoritarian regimes may have different attitudes toward democracy aid from Western donors depending on their regime characteristics.

Wahman, Teorell \& Hadenius's (2013) classifies authoritarian regimes into four types: monarchy, military, one-party, and multi-party. ${ }^{4}$ This classification is useful in teasing out autocratic governments' preferences on foreign aid for several reasons. First, HTW allows me to most accurately define preference of authoritarian regimes on each type of

\footnotetext{
${ }^{3}$ For instance, Geddes, Wright \& Frantz (2014) defines authoritarian regimes with military, monarchy, personalist, and party regime. Cheibub, Gandhi \& Vreeland (2010) categorize authoritarian regimes as monarchic, military, and civilian regimes. Finally, Wahman, Teorell \& Hadenius (2013) classify authoritarian regimes into five core subtypes: military, monarchy, no-party, one-party, and multiparty regimes.

${ }^{4}$ I dropped no-party regime types because of the time frame of my research. The dissertation focuses on the post-Cold War era, and there are only few cases of no-party regimes (Wahman, Teorell \& Hadenius 2013).
} 
democracy aid. HTW categorize authoritarian regime types based on how authoritarian regimes access and maintaining their power (Wahman, Teorell \& Hadenius 2013, 21). It has advantage of most accurately operationalizing perception of authoritarian regimes on democracy aid subtypes regarding their political survival. Second, HTW incorporates institutional features in the regime typology, allowing me to accurately define the 'regimecompatibility' of democracy aid targeting different institutions in authoritarian regimes. Finally, from the technical perspective, it covers a longer period of time than the alternatives, and it allows me to include the longest period in the post-Cold War era. ${ }^{5}$ Although there is limitation using regime types that regime types still cannot capture the difference in competitive authoritarianism (Brownlee 2009, Levitsky \& Way 2010b), WTH has an advantage to capture the overall ruling mechanism and institutional features in various authoritarian regimes with intuitive categorization.

Authoritarian regimes have different preference on democracy aid by subtypes. Table 2.2 shows which types of democracy aid are regime-compatible or regime-incompatible by authoritarian regime types. Each authoritarian regime has different attitude toward democracy aid subtypes depending on their institutional characteristics, level of legitimacy, and sociopolitical conditions.

Regardless of regime types, all types of authoritarian regimes have similar attitudes toward democracy aid for good governance, judiciary, and media. First, democracy aid projects for governance and judiciary system are regime-compatible with all authoritarian regimes. These types of democracy aid help authoritarian governments to maintain

\footnotetext{
${ }^{5}$ Wahman, Teorell \& Hadenius's (2013) covers authoritarian regimes from 1972 to 2014. However, Geddes, Wright \& Frantz (2014) dataset covers authoritarian regimes from 1946 to 2010. Magaloni, Chu \& Min (2013) dataset also covers authoritarian regimes from 1950 to 2012.
} 
Table 2.2: Authoritarian Regime Types and Democracy Aid

\begin{tabular}{|c|c|c|}
\hline & Regime-compatible & Regime-incompatible \\
\hline Multi-party & $\begin{array}{l}\text { Governance } \\
\text { Judiciary } \\
\text { Civil Society } \\
\text { Human Rights } \\
\text { Women's Right }\end{array}$ & $\begin{array}{l}\text { Election } \\
\text { Legislature and Political Party } \\
\text { Media }\end{array}$ \\
\hline One-party & $\begin{array}{l}\text { Governance } \\
\text { Judiciary } \\
\text { Election } \\
\text { Legislature and Political Party } \\
\text { Civil Society } \\
\text { Human Rights } \\
\text { Women's Right }\end{array}$ & Media \\
\hline Military & $\begin{array}{l}\text { Governance } \\
\text { Judiciary }\end{array}$ & $\begin{array}{l}\text { Election } \\
\text { Legislature and Political Party } \\
\text { Civil Society } \\
\text { Human Rights } \\
\text { Women's Right } \\
\text { Media }\end{array}$ \\
\hline Monarchy & $\begin{array}{l}\text { Governance } \\
\text { Judiciary } \\
\text { Civil Society }\end{array}$ & $\begin{array}{l}\text { Election } \\
\text { Legislature and Political Party } \\
\text { Human Rights } \\
\text { Women's Right } \\
\text { Media }\end{array}$ \\
\hline
\end{tabular}

control. Democracy aid for governance is the most favored type of democracy aid. These projects aim to improve the quality of public management system and the ability to provide public services. because most authoritarian regimes provide some level of public services, nearly any type of authoritarian regime can easily justify their use of governance aid. Democracy aid projects for judiciary systems are another highly favored type of aid. A judiciary system is not an exclusive institution of democracy. Most authoritarian regimes have a judiciary system to interpret and apply state law, and it generally serves the 
existing order. Unlike the judicial system in democratic regimes, courts are subordinate to the executive branch and authoritarian leaders can control court decisions. Therefore, authoritarian governments are willing to have these two types of democracy aid if donor countries want to provide these projects.

While aid for governance and the judiciary is favored by all authoritarian regimes, none are eager to accept aid for the media. Authoritarian regimes are particularly cautious about strengthening the media. Control over the media is an important determinant of political survival and regimes stability of authoritarian leaders. The media plays a critical role in shaping public opinion, and free media can stimulate diffusion of anti-government movement or democratic movement in authoritarian regimes. Moreover, to the multi-party or one-party regimes that election, controlled media give opportunities to the incumbents to have "uneven playing field" of election (Levitsky \& Way 2010b). Authoritarian leaders want to control media to maximize propaganda effect and control the criticism against the regime. Most of incumbents in authoritarian regimes are sensitive to democracy aid for media freedom.

\section{Multiparty Regimes}

Multiparty regimes refer to authoritarian regimes that allow competing political parties and hold regular multiparty elections to select leaders and representative of legislatures. Multiparty regimes are typically placed in the 'gray area' between the full-democracy and full autocracy (Schedler 2002b). They voluntarily adopt democratic institutions-such as elections, a legislature, and opposition parties-as a part of survival mechanisms. They allow opposition parties in their regimes and hold multiparty elections to have general 
acceptance on their authority. Multiparty regimes also use legislature and party systems as a power-sharing and co-optation tools for their survival (Gandhi \& Przeworski 2007). Elections in multi-party regimes help incumbent authoritarian regimes to gain legitimacy, get information on their populations on the regimes, and co-opt opposition parties within the regime (Knutsen, Nygård \& Wig 2017). Regular elections in multi-party regimes help authoritarian leaders to identify their support and opposition groups (Knutsen, Nygård \& Wig 2017, Gandhi \& Przeworski 2007).Multiparty regimes have confidence in winning elections because they have strong support groups among citizens, or they can manipulate elections for their winning. The multiparty regime corresponds to categories created by other scholars including 'electoral authoritarian regimes' (Schedler 2002a), 'comparative authoritarian regimes' (Levitsky \& Way 2010a), 'hybrid regimes' (Diamond 2002), or ‘dominant party regimes’ (Magaloni \& Kricheli 2010).

Multiparty regimes are authoritarian regimes that are the closest types to democracy. The institutional features in multiparty regimes are similar with democracy even if they do not function as like ones in democracies. They allow opposition parties in their regimes and hold multiparty elections to have general acceptance on their authority. Multiparty regimes also use legislature and party systems as a power-sharing and co-optation tools for their survival (Gandhi \& Przeworski 2007). Elections in multi-party regimes help incumbent authoritarian regimes to gain legitimacy, get information on their populations on the regimes, and co-opt opposition parties within the regime (Knutsen, Nygård \& Wig 2017). Multiparty regimes have confidence in winning elections because they have strong support groups among citizens, or they can manipulate elections for their winning. 
For multiparty regimes, civil society democracy aid is regime-compatible. This types of democracy aid mainly supports civil society organizations, promotes participation in elections, and improving civil rights. Multiparty regimes rarely consider such aid as a threat because they already have general elections and allow the civil society some freedom in their regimes, and they sustain political power based on support from the citizens. Multiparty regimes are more likely to consider democracy aid for civil society to be an opportunity to distribute more public goods and spoils to loyal supporters (DiazCayeros, Magaloni \& Weingast 2003). In multiparty authoritarian regime, civil society democracy aid increases the budget of multiparty regimes, and it enhances the regime's survival prospects (Greene 2010). This helps multiparty regimes can distribute democracy aid for civil society to parties and civil society organizations that support the regime. They can buy off more loyalty from their support groups using democracy aid. Therefore, multiparty regimes are likely to consider democracy aid for civil society as a positive opportunity.

However, democracy aid for elections, the legislature, or political parties likely poses competing incentives to multiparty authoritarian regimes. On the one hand, multiparty regimes are willing to accept these democracy aid types because of they fund institutions that don't really threaten the regime. Multiparty regimes hold elections or allow opposition parties in their regimes. Furthermore, to multiparty regimes, external support to these institutions can be considered as an opportunity to multiparty regimes because they utilize elections and legislatures as a power-sharing apparatus with potential elite opponents (Magaloni 2008, Brownlee 2007). 
On the other hand, these democracy aid subtypes might strengthen the opposition parties and hamper electoral manipulations. The most immediate threat to multiparty regimes is losing elections. As they recognize the legitimacy of the rule from elections, the opposition can gain power by winning elections. The emergence of a prominent opposition party is the most immediate and critical threat to survival of multiparty regimes. Therefore, multiparty regimes want to repress opposition parties effectively. For instance, CCM (Chama Cha Mapinduzi, 'the Party of the Revolution'), the dominant party in Tanzania continuously suppresses emergence of challenging opposition party in their regime. When Chadema, the second largest party in Tanzania, emerged and the margin of victory for $\mathrm{CCM}$ in the presidential election decreased 32 percent points compared to the previous election in 2010, CCM constricted freedom of the media and assembly in order to contain Chadema's gain ahead of the next election. CCM also suspended newspapers and terminated live television coverage of parliament to hide Chadema's public mobilization (Paget 2017)

Multiparty regimes do not want external support for free and fair election or election monitoring because incumbents utilize various election fraud tactics to ensure their victory. Election fraud is a pervasive phenomenon in multiparty regimes, and incumbent parties implement a multiple visible and invisible tactics (Gandhi \& Lust-Okar 2009). There is various tactics such as vote buying, threatening opposition candidate, passing candidate qualification laws, and appropriating government budget for incumbent election campaigns (Beaulieu \& Hyde 2008). When the margin of victory of elections is small, incumbents are more likely to lean to election fraud for an election victory. 
Also, external support to political parties threatens multiparty regimes because it can embolden the opposition parties. Dissidents can more effectively challenge incumbents through a strong opposition party because it helps them to overcome a collective action problem (Rivera 2017). Opposition parties can gain popularity if there is external support for elections and political parties. For instance, Beaulieu \& Hyde (2008) find that international elections observations on elections can increase the election boycott of opposition parties. Therefore, democracy aid for elections or legislatures and political party can be a double-edged sword to multiparty regimes. Incumbents of multiparty regimes might have advantage from these democracy subtypes, but aid might also strengthen the prominent opposition party or challenger upcoming elections. Therefore, assuming that the primary goal of authoritarian leader is political survival, multiparty regimes will view aid for elections or legislature and political party as risky and prefer instead the much safer aid for civil society.

\section{One-party Regimes}

One-party regimes refer to authoritarian regimes that allow only one legal party (Wahman, Teorell \& Hadenius 2013). Similar to multiparty regimes, one-party regimes adopt democratic institutions such as a party system, elections, and a legislature. They have regular elections for legislatures, but they do not allow opposition parties or there are no effective opposition parties against the regime party. There are two types of one-party regimes, depending on whether they employ ideological legitimization.One-party regimes without ideological legitimization allow other parties or competitive elections, but a ruling party is a de facto party. Contemporary Uzbekistan or Tanzania (under CCM until 1994) are two 
examples of such regimes. Second, one-party regimes with ideological legitimization. A party leaning on ideology is usually de jure party in the regimes, and they totally control the governments. Most communist or socialist regimes such as North Korea, China, or Vietnam belong to this type (Kailitz 2013).

A common characteristic of one-party regimes is that they are relatively more stable than other types of authoritarian regimes. There are no prominent political oppositions in the regimes. According to Magaloni \& Kricheli (2010), more than 85 percent of one-party regimes originate from military or multiparty regimes when a dominant party (or group) stifles their opposition party. ${ }^{6}$ In one-party regimes, incumbent parties prohibit opposition parties by law or there are no substantive opposition parties in their regimes. This means that there are no significant challengers. The absent of a de facto opposition party also means that there is no institutional pivot to organize social movements and dissidents effectively. Furthermore, institutions in one-party regimes such as legislatures or regimes party help one-party regimes can incorporate potential opposition groups. Therefore, oneparty regimes may have less worries of being defeated at the elections as well as strong anti-governmental movements from the bottom.

One-party regimes consider democracy aid types for democratic institutions such as elections, political parties, and legislature to be regime-compatible. They are opened to accepting democracy aid for these institutions because they recognize these external sup-

\footnotetext{
${ }^{6}$ One-party in my dissertation refers to the single-party in the Magaloni \& Kricheli's (2010) typology. Magaloni \& Kricheli (2010) categorize authoritarian regimes into dominant party, single party, military, and monarchy. Single-party regimes is defined as authoritarian regimes allow one legal party in their regimes. Dominant party refers to multiparty regimes that authoritarian regimes allow multiparty elections to select political leaders. However, one-party in their typology refers to the both single-party and multiparty regimes.
} 
ports contribute to their survival or at least do not harm their regime stability at least. First, one-party regimes prefer democracy aid for democratic institutions because they possess nearly complete control over them. Similar to multiparty regimes, one-party regimes adopt forms of democratic institutions to maintain and prolong their power rather than to promote democratization (Gandhi \& Przeworski 2007). Second, incumbent parties in the regime are dominant. Their strength means they can accept external support for to minor parties, election, or legislatures without their power being threatened. Bunce \& Wolchik (2010) finds that an incumbent in stable regimes rule through a well-established party. Unlike multiparty regimes, authoritarian leaders in one-party regimes are unlikely to lose their power from the election because there are no prominent challengers in their elections. Therefore, one-party regimes may not consider democracy aid types for elections, political parties or legislatures as a threat.

To the one party authoritarian regimes, democracy aid for civil society is both an opportunity and a threat to the regime. External support to the civil society has an ambivalent effect on the authoritarian regime survival depending on the confidence of public support to the regime. On the one hand, it can threaten to the authoritarian regimes because it can strengthen civil society organization and foster democratic norms and participation. As a result, democracy aid can increase the risk of anti-governmental movements for democratic transition against authoritarian regimes. On the other hand, democracy aid for civil society is an opportunity to the authoritarian regimes to have more resources to buy loyalty or support from the public.

To one-party regimes, democracy aid for civil society is regime-compatible. They may 
consider this type of democracy aid as an opportunity for their political survival rather than a threat because of their strong support and control on the civil society. Historically, one-party regimes came to power with a landslide victory from elections. Around two thirds of one-party regimes are originated from multiparty regimes by defeating opposition parties at the elections (Magaloni \& Kricheli 2010). For instance, Islam Karimov, from Uzbekistan People's Democratic Party (UPDP), was elected with 86 percent vote at the first Uzbekistan presidential election in 1991, and he re-elected in 2000, 2007, and 2015 presidential elections with over 90 percent of vote. In the similar vein, elections in one-party regimes reduce the risk of anti-governmental movements from the bottom. Although elections in one-party regimes are distorted, it has an effect of ratifying the dominance of ruling power (Gandhi \& Lust-Okar 2009). Furthermore, the absent of significant opposition party in one-party regimes is also increase regime confidence on civil society. There is no institutional pivot that can organize social movements against incumbent regimes. Scholars argues that demands for democratic transition cannot be realized without the prominent opposition parties that can replace authoritarian regimes. Therefore, one-party regimes are more likely to have democracy aid for civil society to have extra resources to provide more benefits to entice loyalty.

\section{Military Regimes}

Military regimes are a type of authoritarian regime in which "the armed forces control access to the principal positions of power" (Magaloni 2008, 731). A major attribute that distinguishes military regimes from other regimes is that military officers hold power, control the governmental bureaucracies, and exercise influence over policy (Geddes 2003). There 
are variations among military regimes. Military regimes refer to both a regime that is controlled by a single military officer as a dictator or a regime that is under control of military institutions such as military juntas in Latin America (Geddes, Frantz \& Wright 2014). Dictators in the former types have more concentrated power compared to the later types. They consolidate their power via purging military officers after a coup d'état and replacing key positions in the military and civilian governments with loyal officers. Park Chung Hee in south Korea, Idi Amin in Uganda, Rafael Trujillo in the Dominican Republic, and Mobutu Sese Seko in Zaire are belong to this type of military regimes. The later type of military regime concentrates power in military-led organizations, and they designate a leader among them. The institutions consist of high-ranking military officers who control the civilian government and make decision on policies as the highest authority. Myanmar, Argentina, and Egypt belong to this type.

Military regimes are vulnerable because of their ruling mechanism. Historically, they are shorter-lived than other authoritarian regimes (Geddes 1999a). Military dictators maintain their power via a small winning coalition using intense repression of political rights and civil liberties. Compared to electoral authoritarian regimes, military regimes have small winning coalitions (Bueno de Mesquita et al. 2003). Military dictators are not selected by free and fair elections, but build their power on military force. They only need to have loyal commitment from core support groups in military or civilian groups. To military dictators, the most credible and critical threat is also coup d'état from military. Therefore, they provide private goods to core support groups and have loyalty in exchange. They also conduct coup-proofing activities not to make prominent challengers emerging 
(Talmadge 2015). Maintaining the grip on armed forces in military is also important for political survival because it help them to have coercion on demand for democratization of citizens. They put down protesters, assassinate opponents, and monitor dissents trough military forces.

Democracy aid for democratic institutions such as election, political party, and legislatures are regime-incompatible to military regimes. Military regimes may hesitate to take external support for democratic institutions because it increases uncertainty and instability of the regime. Compared to party type authoritarian regimes, military regimes rarely adopt democratic institutions so they have less ability to co-opt opponents and have little public support to rely on (Magaloni \& Kricheli 2010). Some military regimes adopt democratic institutions in their regime, but they are mere formalities. Therefore, accepting external support for elections, political party, or legislatures can only pose a risk to a military regime. Second, external supports for democratic institutions can increases instability of regimes. Democracy aid for these institutions can give an opportunity to civilian opponents while military dictators occupied the civilian government using force and incapacitated previous political institutions in the regime.

Military regimes may consider democracy aid for civil society and human rights promotion. Military regimes are the most vulnerable regimes, and the life span of military regimes is shorter than other regime types (Geddes 1999b, Hadenius \& Teorell 2007, Kailitz 2013). One reason is that dictators in military regimes are not justified by inherent rights to rule like monarchs or are not approved by free and fair elections. Most of military regimes are established using coup d'état (Wahman, Teorell \& Hadenius 2013). To mil- 
itary regimes, anti-governmental movements like protests, riots, and demonstrations are significant threats. They rely on repression. Although there are mixed findings, military regimes lean on repression more than on other regimes (Geddes, Frantz \& Wright 2014). Davenport (2007b) also finds that military regimes are more likely to commit more physical integrity violations than civilian-led regimes. Poe, Tate \& Keith (1999) also find that military regimes more human right violence than civilian regimes. Military regimes maintain their stability using repression against civilians, and military dictators do not want to external supports that can break status quo balance of power.

\section{Monarchies}

A monarchy is a type of authoritarian regime with an executive office that is selected by a royal family that is considered to have a hereditary right to role. Monarchs in monarchies are at the helm in the regimes. In this regard, polities in which monarchs are bound their exercise of power by legal frame or are not substantive head of government are not considered as monarchies such as United Kingdom, Spain, or Japan. Monarchy was the dominant form of rule in the pre-modern world, but there are only few monarchies in the modern era (Gerring et al. 2020). The expansion of civil liberties makes monarchy is not a prevalent from of polity in the modern era. Most of modern monarchies are placed in Middle East and North Africa (MENA) such as Oman, Morocco, and Saudi Arabia. Few of them are in the non-MENA region such as Swaziland, Brunei, and Bhutan (before 2008).

Political stability in monarchies is relatively higher compared to other authoritarian regimes. There are low political conflicts in monarchies compared to non-monarchies 
(Menaldo 2012). During the Arab Spring in 2011, except the Brain, grassroots protests for democratization did not succeed in monarchies in MENA area while other authoritarian leaders had to step down from power in Tunisia, Egypt, and Yemen. One reason of regime stability of monarchies is that political legitimacy of monarchs' rule is high. Monarchs are considered to have "God-given natural, historical or religious right to rule" (Kailitz 2013). This notion is formed from long-lasting belief and practices among people so that they accept authority of monarchs in the regime. People are barely against the regime when there is significant social or political incidents or event in the regime. Another reason of regime stability is that most of monarchies have capability to buy off loyalty of citizens. Most of monarchies are rentier states. They have extra resources from natural resources or external support so that they are not necessary to depend on tax revenues but also can provide public service and distribute rent to their support groups and people. These mechanisms increase satisfaction on current regimes and reduce probability of social unrest against the regimes. The rent from extra resource help monarchies to reduce pro-democratic pressure (Ross 2004). For instance, UAE provides various rents using oil money to their citizens including free education, marriage fund, free land, and interest-free loan. On average, an Emirate male receives around $\$ 55,000$ a year from their government (Toledo 2013).

Monarchs consider democracy aid for their civil society to be regime-compatible. They may consider that external supports to civil society is not a significant threat to their survival. A traditional authority justifies rule of monarchs and people generally accept the rule of monarchs and are not likely to be dubious about loyal authority without a signifi- 
cant incident. The legitimacy justifies the rule of monarchs because it consists of different components such as religion, tradition, and ideology (Bank, Richter \& Sunik 2013). Most of monarchies in MENA experienced low protest and moderate demand during Arab spring in 2011 (Yom \& Gause III 2012). Also, most of modern monarchies are rentier states and they can buy off loyalty of people and mitigate democratic movements against monarchies without taxation. The meaning of no taxation stands for no representation so that most people are less likely to have high demand for democratization (Lucas 2004). Furthermore, monarchies rest upon complicated social cleavages based on ethnicity, religion, tribe, and economic class. This makes monarchs apply a divide-and-rule tactic and have small 'cross-cutting coalition' (Yom \& Al-Momani 2008). Therefore, monarchies are more likely to consider the democracy aid for civil society or human rights is extra resource for rent rather than a threat.

However, monarchs consider democracy aid types for human rights or women's right as regime-incompatible. The legitimacy of monarchies is intertwined with traditional or religious belief and practice, and they come into conflict with human rights or women's right from the Western perspective. To monarchs, external support for human rights or women's right can be considered as a threat to their traditional authority. For instance, there have been various regulations and restriction based on Islamic culture to women in monarchies in the MENA such as education, political participation, dress code, and marriages. UAE allowed women suffrage in 2006 and Saudi Arabia allow it in 2015.

Monarchies also consider democracy aid for democratic institutions such as political party, legislatures, and elections to be regime-incompatible. Although there are ar- 
guments that democratic institutions provide institutional flexibility to deal with structural economic and social change, but external support for democratic institutions can be considered as a significant threat to monarchs. King's dilemma, a famous notion of Samuel Huntington, emphasizes a key problem modern monarchies face (Huntington 1968). Monarchs have to make a decision whether they stay in traditional monarchy or turn to constitutional monarchies toward a demand for political modernization. It is not an immediate threat to monarchs but allowing democratic institutions may be the first step toward constitutional monarchy. Allowing political party or legislatures can play a pivot of democratic movements and election can be used an institutional tool of regime breakdown. Furthermore, Monarchies want to solve the problem in their own pace without external intervention. Maintaining status quo is the best strategy to the monarchs because they have capacity for maintaining current absolute power without democratic institution. They want to adopt democratic institutions based on their own face without external intervention. Therefore, external support for democratic institutions can be threatening to monarchies. Monarchies do not want democracy aid for democratic institutions.

\subsubsection{Strategic Response of Authoritarian Regimes Toward Democracy Aid}

Authoritarian regimes have a different attitude toward democracy aid. They make a strategic choice about accepting democracy aid because it has ambivalent characteristics between extra resources and external intervention to domestic politics. Authoritarian regimes generally are willing to have democracy aid because they can relieve budgetary constraints. However, democracy aid, when targeting vulnerable political institutions and 
norms, can destabilize the current political equilibrium and make authoritarian regimes more vulnerable. Depending on domestic conditions and interests, authoritarian regimes have different preferences on regime-compatible and regime-incompatible democracy aid.

Authoritarian leaders are willing to calibrate democracy aid flow depending on their political situation. They may perceive more threats from regime-incompatible democracy aid when they have unstable domestic political situations because of their limited capability. They are more selective on external opportunities if there are more threats from inside of regime. Domestic political challenges such as anti-governmental demonstrations, protests, or turmoil may make authoritarian regimes are more vulnerable to external intervention. Coup attempts from ruling elite groups or prominent political opponents are also significant and immediate threats to authoritarian regimes. Authoritarian leaders are more likely to be more selective about democracy aid to minimize the external influence on political stability.

However, authoritarian regimes have greater need for regime-compatible democracy aid while facing more political challenges. As I explained earlier, authoritarian regimes are likely to perceive fewer threats from regime-compatible democracy aid. Regime compatible democracy aid does not go to the opponents in authoritarian regimes or is not targeting the weak institutional points in the regime. Furthermore, regime-compatible democracy aid has similar feature with oil to authoritarian leaders. They can appropriate fungible aid to pay off the royalty of political elites and support from the public. Authoritarian regimes perceive regime-compatible democracy as an opportunity to relieve 
domestic threats and are willing to have regime-compatible democracy aid.

When authoritarian leaders have internal political threats, the best strategic choice on democracy aid is maximizing regime-compatible democracy aid and minimizing regimeincompatible democracy aid. Although recipient countries are active actors in aid allocation process, donors have a priority on aid allocation because a willingness of donors is a primary necessary condition for foreign aid allocation. Authoritarian regimes have small leverage over donors in aid allocation process. If authoritarian regimes fail to achieve their preference during a aid allocation negotiation with a donor, the only remaining option is not accepting the aid offer. However, if authoritarian regimes have leverages over donors in aid allocation, they can reflect the preference during aid allocation negotiation.

Which authoritarian regimes have more leverage over donors during aid allocation negotiations? My argument is that authoritarian regimes that are clients of donors have more leverage over the donors. If donors have security or economic interests on authoritarian regimes, donors are more supportive to them. To the donors, there is no reason to threaten clientelistic authoritarian regimes who serve donors' interests. Rather, donors are more likely to support an authoritarian leader for stable political environment. Therefore, if authoritarian regimes are clients of donors, these authoritarian regimes can have more leverage over donors in democracy aid allocation. Compared to neutral or antagonistic authoritarian regimes, clientelistic authoritarian regimes are more likely to have more regime-compatible democracy and reduce regime-incompatible democracy aid using their leverage.

From the donors' perspective, a domestic political disturbance is an opportunity for 
democracy promotion. Democracy aid can be more effective for attenuating authoritarian regimes or promoting democratic movements. If an authoritarian regime is not a client state of donors, donors are more likely to provide aggressive democracy aid to authoritarian regimes. Furthermore, from a strategic viewpoint, it is a good opportunity to break antagonistic authoritarian regime or attenuate them at least with a good normative goal, democracy promotion. Therefore, donors are more likely to provide more regimeincompatible democracy aid to recipient countries or at least reduce regime-compatible democracy aid at least when authoritarian regimes have trouble in their domestic politics.

Hypothesis 2 Authoritarian regimes are more likely to have regime-compatible democracy aid from donors in patronage relationships if authoritarian regimes have higher political instability.

Hypothesis 2a Authoritarian regimes are more likely to have regime-incompatible democracy aid more while under political instability if they do not have patronage relationships with donors.

In this chapter, I develop a theoretical argument on democracy aid allocation to authoritarian regimes. It is a unique allocation mechanism to democracy aid when authoritarian regimes consider them both an opportunity and a threat. I theorize the divergent traits of democracy aid as regime-compatible democracy aid and regime-incompatible democracy aid. Authoritarian regimes have a different decision on the 'regime compatibility' of democracy aid based on the domestic conditions in their regimes. Donors also make a strategic choice on types of democracy aid to achieve various foreign policy goals. My theoretical arguments provide how the political interests of both donors and recipients 
affect the composition of democracy aid and its allocation patterns. In the following chapters, I test my theoretical arguments using U.S. democracy aid allocation to authoritarian regimes. 


\section{Chapter 3}

\section{The Supply Side: How does the U.S. Distribute Foreign Aid?}

Foreign assistance is an innovative instrument of foreign policy in the modern era (Morgenthau 1962). Although there has been a conventional argument on donors' motivations for providing aid, the bottom line of foreign aid allocation is that it is a foreign policy tool used to achieve various foreign policy goals with other countries. From the donors' perspective, it implies two important characteristics of foreign aid allocation patterns of donors. First, donors pursue various foreign policy goals. These provide donors with different motivations in foreign aid allocation, such as self-interests, needs of recipient countries, and altruistic and humanitarian motivations. Second, as an instrument of foreign policy, donors must account for the relationship with recipient countries when they allocate foreign aid. Donors consider the impact of foreign aid on their relationship with recipient countries as well as the effect of foreign aid on recipient countries themselves. Foreign aid allocation is not a one-shot game. They have to consider other relationships with a recipient country. Additionally, the multiple goals or interests of donors in recipient countries shape the different balance of power between donors and recipient countries. Therefore, donors have a more flexible foreign aid policy depending on their relationship with a recipient county. 
In this regard, donors have various policy options regarding foreign aid allocation. They may have strategic decisions on volume, types, and delivery mechanisms of foreign aid. It changes the characteristics of foreign aid in achieving the goals and the impact on the relationship with recipient governments.

Democracy aid allocation operates under a similar process. As discussed in Chapter 2, donors - particularly Western democratic donors- have different goals for democracy aid. They want to spread democracy in the world, but they also want to look after security or economic interests from recipient countries by providing democracy aid. Unlike development aid or humanitarian aid, democracy aid aims for political reforms in recipient countries, and some types can threaten the political stability in authoritarian regimes depending on the subtypes of democracy aid. It makes donors have a strategic choice on democracy aid allocation. Donors provide different volumes and types of democracy aid to authoritarian regimes. Particularly, between regime-compatible democracy aid and regime-incompatible democracy aid, donors make different decisions to achieve their strategic goals.

In this chapter, I test my hypothesis on the strategic decisions of donors on democracy aid allocation. I figure out whether donors provide more regime-compatible democracy aid to support authoritarian regimes with a focus on U.S. democracy aid allocation (H1). I test my hypothesis with the U.S. case because of practical limitations. It is hard to define all relationships between all OECD DAC donors and their recipient countries. However, it has the advantage of showing the impact of donors' strategic choices on democracy aid allocation. Furthermore, I believe that the U.S. is the most representative donor of 
democracy aid, as it is both the largest democracy aid donor and the leading donor in democracy aid allocation.

\subsection{U.S. Democracy Aid Allocation}

Historically, the U.S. has claimed advocating democracy is one of their foreign policy goals. In line with the goals, the U.S. has been the most prominent and long-standing donor of democracy aid in the world. During the Cold War era, democracy promotion was a "tool" for fighting against Communism. The U.S. advocated democracy to protect the "Free World." Notably, during the 1960s and 1970s, U.S. democracy aid policy was based on modernization theory, and the U.S. tried to promote democracy aid through economic development (Carothers 2000). The current democracy aid programs were shaped during the 1980s. The U.S. designed more direct democracy aid programs to foster democratic infrastructures in recipient countries, such as free and fair elections, political parties, legislatures, and judiciary systems in the recipient countries. National Endowment for Democracy (NED), one of the prominent democracy assistant organizations, was established in 1983. USAID and NED tried to support developing democratic institutions in the world. For instance, they provided election assistant programs in Latin America during the 1980s. However, national security was still a dominant foreign policy goal for the U.S. during the Cold War era, and most of the democracy aid programs were focusing on programs for human rights and civil liberties (Goldsmith 2001)

The collapse of the Soviet Union presented a significant opportunity for U.S. democracy aid allocation to make substantial progress. The end of the Cold War symbolized a winning of the Free World against Communism. It increased the confidence of the U.S. in 
the supremacy of democracy. The victory also alleviated the national security concerns. The U.S. was able to pursue a more flexible democracy promotion policy because the U.S. did not have to support allies from the Communist camp. The U.S. escaped from an old policy compulsion of supporting anti-communist authoritarian regimes. As a result, the U.S. became more flexible on democracy promotion. It increased the volume of democracy aid and, at the same time, diversified democracy promotion strategy in the new environment. U.S. democracy aid eventually came to concentrate on human rights and civil liberties during the 1980s. The U.S. targeted more democratic institutions directly, such as supporting free and fair elections, multi-party systems, and judiciary system since the 1990s.

According to the AidData (Tierney et al. 2011), the U.S. has increased foreign aid as well as democracy aid since the 1980s. U.S. foreign aid was around 336 million U.S. dollars in 1980. However, the U.S. increased it to 793 million U.S. dollars in 1990, and the total of U.S. foreign aid exceed 2,000 million U.S. dollars in 2003. Second, an increasing pattern can be observed within the data on the proportion of democracy aid in total foreign aid. Democracy aid was only around 3 percent of the total of U.S. foreign aid in 1980. It was increased to 8.4 percent in 1990. The U.S. made up 18.1 percent of foreign aid with democracy aid in 2010. Although there were some fluctuations, the U.S. government did put more democracy aid projects in their foreign aid portfolio after the Cold War.

The U.S. provides more democracy aid to authoritarian regimes than democratic countries. Figure 3.1 shows U.S. democracy aid allocation patterns by recipient regime types. First of all, U.S. democracy aid has been increasing dramatically. U.S. democracy aid is 


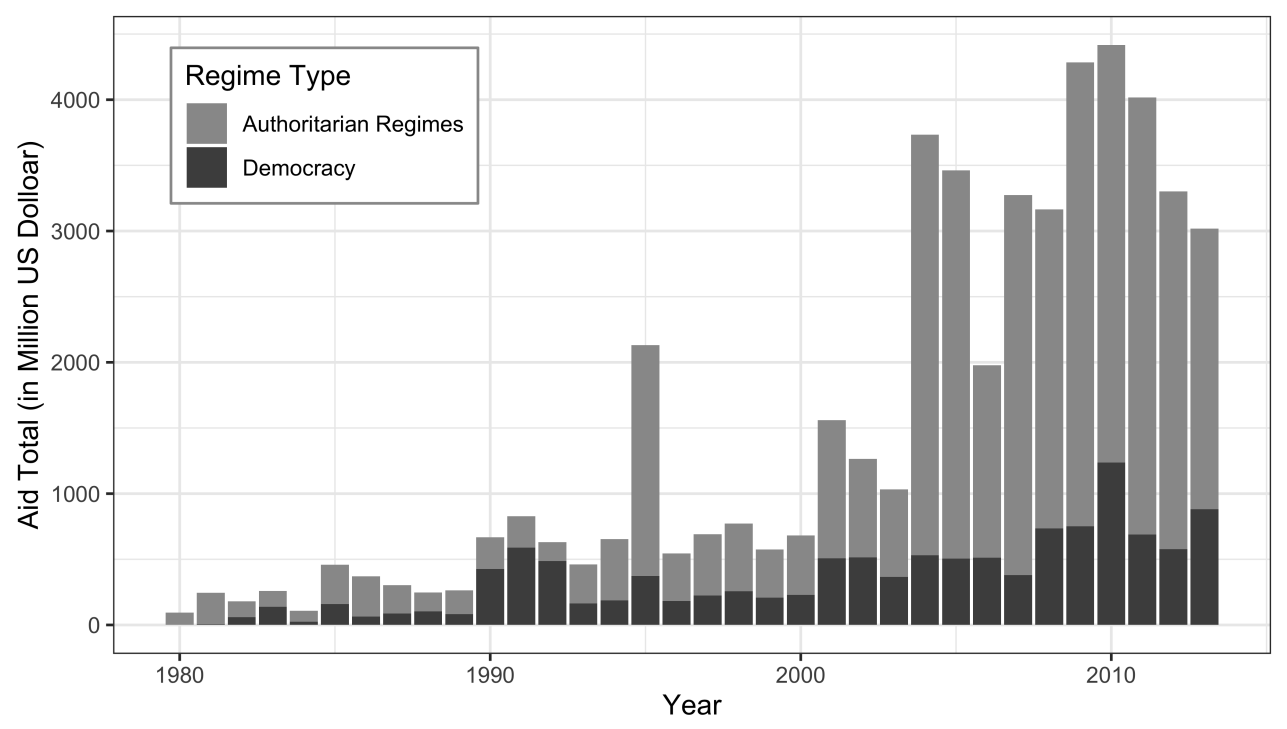

Figure 3.1: U.S. Democracy Aid Allocation by Recipient Regime Types (1980-2013) Source: AidData 3.1 (Tierney et al. 2011)

less than 500 million U.S. dollars during the 1980s, but it has increased over time and is more than 4,000 million U.S. dollars in 2010. Also, one interesting characteristic of U.S. democracy aid allocation is the large proportion of democracy aid has delivered to authoritarian regimes. In most years, the U.S. delivered two-third of democracy aid to authoritarian regimes. The U.S. has provided more democracy aid to authoritarian regimes after the 2000s. Most increased democracy aid during the 2010s goes to authoritarian regimes. The figure shows that U.S. democracy aid is more oriented to democratic transition in authoritarian regimes than consolidating democracy in democratic countries.

Although the U.S. has more flexibility regarding democracy promotion, this does not mean that the U.S. is a selfless donor of democracy. Even in the new security environment of the post-Cold War era, the U.S. needs to make a strategic decision between various motivations and interests regarding democracy promotion. As discussed in Chapter 2, the normative motivation toward democracy promotion may compete with donors' security 


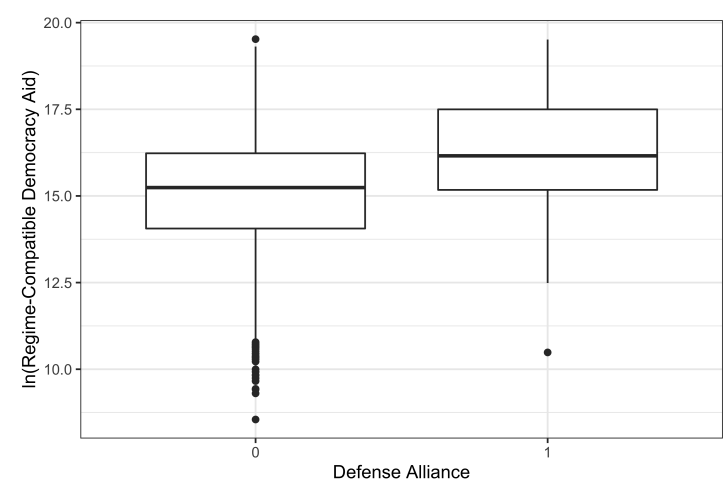

(a) Defense Alliance

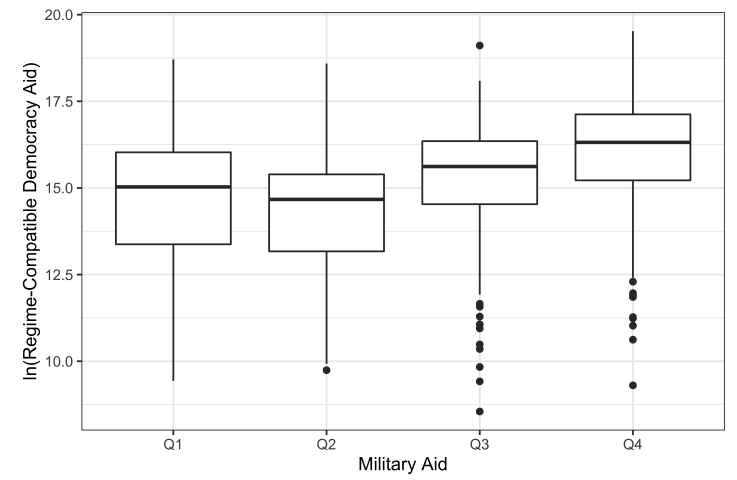

(b) Military Aid

Figure 3.2: Regime-Compatible Democracy Aid Allocation (1990-2013) Source: AidData 3.1 (Tierney et al. 2011)

and economic interests. The U.S. may not want to disturb the status quo relationship with recipient countries by increasing aggressive democracy aid to authoritarian regimes.

Figure 3.2 describes the brief relationship of regime-compatible democracy aid allocation patterns over defense alliance and military aid allocation. Figure 3.2 (a) shows that authoritarian regimes in a defense alliance with the U.S. are more likely to have more regime-compatible democracy aid. Figure 3.2 (b) shows the democracy aid allocation over each quantile of military assistance. It shows how the security interests of the U.S. affect democracy aid allocation. The U.S. is more likely to provide military assistance to a recipient country if the country is vital for the U.S. security interests in the region (Sylvan \& Majeski 2009). The plot in Figure 3.2 (b) illustrates that recipient countries in the fourth quantile of military aid are more likely to have more regime-compatible democracy aid than recipient countries in the first or second quantile. In summary, the figures demonstrate that the U.S. considers the relationship with recipient countries and national interests in the countries. 


\subsection{Research Design}

I develop a dataset to test hypotheses on donors' democracy aid allocation strategy to authoritarian regimes. The dataset includes U.S. democracy aid allocation to authoritarian recipient countries from 1990 to 2013. I focus on the post-Cold War era because the U.S. has different practices and tactics in democracy aid allocation practices and tactics before and after the collapse of the Soviet Union. Also, Western donors, including the U.S., have increased democracy aid dramatically from the 1990s. I only include authoritarian regimes among recipient countries of U.S. democracy aid and exclude democratic countries because donors have a different democracy aid allocation strategy, and democratic regimes have an odd attitude toward democracy aid from Western donors. I also exclude small island countries to prevent bias from outliers.

\subsubsection{Dependent Variables: Democracy Aid}

The key independent variable is regime-compatible democracy aid. To calculate regimecompatible democracy aid, I operationalize democracy aid among the foreign assistance first. I define democracy aid as foreign assistance for promoting democratic institutions such as governance, elections, legislatures, civil rights, and human rights in a recipient country. I operationalize democracy aid based on the OECD DAC purpose codes belong to civil society and the government sector (DAC 5 Sector 151).

Scholars have utilized a variety of different measurements to capture U.S. democracy assistance. For instance, Scott \& Steele (2005) operationalize democracy assistance with democracy grants from the U.S. National Endowment for Democracy (NED). Some 
scholars measure democracy assistance based on the USAID Greenbook categories (Finkel, Pérez-Liñán \& Seligson 2007). Kalyvitis \& Vlachaki (2010) includes foreign assistance, both civil society and government (DAC 5 Sector 151), and conflict, peace, and security (DAC 5 Sector 152). In my research, I follow the OECD DAC classification and only include foreign aid allocations belong to DAC5 Sector 151. I do not include foreign aid for peacebuilding (DAC5 Sector 152). This is because they are more likely to allocate conflict-affected countries with higher political instability, or a central government may not have enough capability to control their territory and have unusual political instability.

I extract U.S. foreign assistance to authoritarian regimes between 1990 and 2013 from AidData 3.1 (Tierney et al. 2011). Among 67,095 aid projects from the U.S. to authoritarian regimes, I define 15,376 foreign assistance projects as democracy aid based on the DAC purpose codes. ${ }^{1}$

I also categorize U.S. democracy aid projects into eight different subtypes based on OECD DAC codes (See Appendix B): 1) Governance, 2) Judiciary, 3) Election, 4) Legislature and Political Party, 5) Media, 6) Civil Society, 7) Human Rights, and 8) Women's Right. Each sub-type of democracy aid stands for key dimensions of democracy for democratization in authoritarian regimes. I aggregate yearly totals for sub-types of democracy aid by recipient countries.

I calculate regime-compatible democracy aid based on subtypes of democracy aid and authoritarian regime types. Authoritarian regimes have different levels of legitimacy and political conditions, so that they make authoritarian regimes have divergent attitudes toward democracy aid where aid projects are targeting. I use HTW Authoritarian Regime

\footnotetext{
${ }^{1}$ I define regime types of recipient countries based on Wahman, Teorell \& Hadenius (2013).
} 
Type dataset (Wahman, Teorell \& Hadenius 2013). The data categorizes authoritarian regimes into four types: multi-party, one-party, military, and monarchy. I calculate democracy aid based on my theoretical arguments on authoritarian regimes (See Table 2.2). I operationalize regime-compatible democracy aid in two ways: I employ the total of regime compatible democracy aid as my primary measurement to capture tactical allocation of democracy aid to authoritarian regimes. I employ a log transformation to compress the large scale of foreign aid. They are measured in constant 2011 U.S. dollars. Alternatively, I generate the percentage of regime-compatible democracy aid over total democracy aid.

\subsubsection{Independent Variables: Donor Interests}

I apply different measurements to capture the donor-recipient relationships between the U.S and authoritarian regimes. I operationalize the relationship using the U.S. interests on recipient countries. This is because donors' willingness and interests are the essential determinants of democracy aid allocation at the first stage. Furthermore, the influence of authoritarian regimes is negligible when we consider the relative size and between the U.S. and recipient countries. Therefore, we can define the donor-recipient relationship between the U.S. and authoritarian regimes based on U.S. interests in authoritarian regimes.

I apply two different groups of proxies to measure the relationship of the U.S. toward authoritarian regimes in recipient countries: economic interests and security interests. First, I use two variables to measure the economic interests following previous studies. The first measurement of economic interests are crude oil imports (Oil Import). Oil is the most crucial energy resource, and it is vital to secure oil for economic development. The U.S. may have a client relationship with oil export counties to the U.S. The U.S. is 
more likely to support authoritarian regimes and give more favor to them to secure their oil supply. The oil import variable measures the percentage of crude oil import from the total U.S. crude oil import. I use data from the U.S. Energy Information Administration. ${ }^{2}$ The second measurement of economic interests are total imports and exports between the U.S. and a recipient country (Trade). In a similar vein, the U.S. is more likely to be supportive to trade partners to secure economic interests. I use U.S. trade data from the Correlates of War Projects (Barbieri \& Keshk 2016). I use the logged value of trade to compress extreme variation in trade between countries.

I also use four measurements to capture the security interests of the U.S. following the previous research: defense alliance, UNGA voting similarity, U.S. military aid, and the number of terrors (e.g., Lai \& Morey 2006, Fleck \& Kilby 2010, Hoeffler \& Outram 2011, Bermeo 2017, Rose 2017). Like the economic interests, the U.S. is more likely to be supportive to a recipient county if they serve the security interests of the U.S. First, I measure whether an authoritarian regime is a defense alliance of the U.S. or not (Defense Alliance). A defense alliance is the most potent form of a supportive relationship between countries. Particularly, the U.S. has been selective on defense alliance, and they have signed a mutual defense treaty if a country is important for their security interests in a region. I coded Defense Alliance equals 1 if a recipient country signed a collective defense arrangement with the U.S. otherwise 1. I draw this variable from COW Formal Alliance Data 4.1 (Gibler 2009).

The second measure is the voting similarity in UN General Assembly (UNGA Vot-

\footnotetext{
${ }^{2}$ U.S. Energy Information Administration, "Petroleum \& other liquids." https://www.eia.gov/dnav/pet/ pet_move_imp_dc_NU.S.-Z00_mbblpd_m.htm (retrieved: 6.25.2021).
} 
ing similarity). Recipient countries with a supportive relationship with the U.S. are more likely to have voting compliance with the U.S. in UNGA (Lai \& Morey 2006, Dreher, Nunnenkamp \& Thiele 2008). UNGA Voting similarity index ranges from 0 to 1 each year (Voeten, Strezhnev \& Bailey 2009).

As my third measurement, I employ military aid flows to a recipient county (Military Aid). The U.S. provided military aid to recipient countries that hold strategic interests in a region (Poe \& Meernik 1995). The U.S. provides military aid to enhance the recipient government's political stability or otherwise help them maintain regional security on behalf of the U.S. I measure total amount of U.S. military assistance to a recipient country. ${ }^{3}$ I utilize a logarithmic transformation to compress the large scale of military aid.

Finally, I include the frequency of terrorism in recipient countries to measure security concerns of the U.S. in recipient countries (Terror). The George W. Bush Administration stressed that democracy promotion is a method of combating terrorism in the $2006 \mathrm{Na}$ tional Strategy for Combating Terrorism (Perl 2007). The previous studies argue the relationship between foreign aid allocation and terrorism (Azam \& Thelen 2009, Bandyopadhyay, Sandler \& Younas 2011, Bapat 2011b). Particularly, the U.S. allocates more foreign aid to recipient countries with terrorist activities that target the U.S. citizens (Neumayer \& Plümper 2011, Boutton \& Carter 2014). Terror measures the total number of terrorism incidents in a recipient country. I draw the data from the Global Terrorism Database. ${ }^{4}$

\footnotetext{
${ }^{3}$ U.S. Agency for International Development (USAID), "U.S. Overseas Loans and Grants: Obligations and Loan Authorizations, July 1, 1945-September 30, 2018," https://explorer.usaid.gov/reports (retrieved: 6.25.2021).

${ }^{4}$ National Consortium for the Study of Terrorism and Responses to Terrorism (START), University of Maryland (2019), The Global Terrorism Database, https://start.umd.edu/gtd/ (retrieved: 6.25.2021).
} 


\subsubsection{Control Variables}

I include several control variables that can affect U.S. democracy aid allocation following previous research. I control the Population and GDP per capita. Democracy aid can be affected by the size of a country or the level of economic development. I draw both variables from the World Bank and have log transformation to compress the extreme variations between countries. Annual Polity scores are included to control for the political conditions within recipient countries (Marshall \& Gurr 2020). I rescale the score ranges from 0 to 10 for better interpretation. Alternatively, I also use the difference of polity scores compared to the previous year (Polity $(F D))$. This measurement is more suitable for measuring the fluctuation in a regime without level effect from regime type difference. This is because the dependent variable-regime-compatible democracy-is based on the types of authoritarian regimes. Finally, Disaster Death measures the total number of deaths due to natural disasters in a year. I draw disaster data from EMDAT-CRED. ${ }^{5}$.

\subsection{Empirical Results}

To test my hypotheses, I utilize Prais-Winsten regression models. This method allows us to correct for serial correlation, particularly first-order $(\mathrm{AR}(1))$ autoregressive processes using the generalized least-squares (GLM) method (Wooldridge 2016, 383). Donors usually provide democracy aid in a multi-year project because political development requires a long-term approach. Therefore, foreign aid allocation to the same recipient country has a serial correlation over time. To correct a serial correlation of democracy aid allocation

\footnotetext{
${ }^{5}$ Centre for Research on the Epidemiology of Disasters (CRED), Emergency Events Database (EMDAT), http://www.emdat.be/ (retrieved: 6.25.2021).
} 
patterns, I utilize Prais-Winsten models with cluster-robust standard errors at the countryyear level. I also estimate the same models using random effect models to check for robustness (See Appendix C).

Table 3.1: Prais-Winsten Estimations on Total of Regime-Compatible Democracy Aid

\begin{tabular}{|c|c|c|c|c|c|}
\hline & \multicolumn{5}{|c|}{ Dependent variable: } \\
\hline & \multicolumn{5}{|c|}{ Total of Regime-Compatible Democracy Aid of the U.S. } \\
\hline & (1) & (2) & (3) & (4) & (5) \\
\hline Oil Import (\%) & $\begin{array}{l}-0.184^{* * *} \\
(-3.59)\end{array}$ & $\begin{array}{l}-0.167^{* * *} \\
(-3.40)\end{array}$ & $\begin{array}{l}-0.159^{* * *} \\
(-3.43)\end{array}$ & $\begin{array}{l}-0.158^{* * *} \\
(-3.34)\end{array}$ & $\begin{array}{l}-0.153^{* * *} \\
(-3.41)\end{array}$ \\
\hline ln.Total Trade & $\begin{array}{l}-0.00340 \\
(-0.04)\end{array}$ & $\begin{array}{l}0.0000362 \\
(0.00)\end{array}$ & $\begin{array}{l}-0.0200 \\
(-0.23)\end{array}$ & $\begin{array}{l}-0.0191 \\
(-0.22)\end{array}$ & $\begin{array}{l}-0.0455 \\
(-0.52)\end{array}$ \\
\hline Defense Alliance & $\begin{array}{l}1.450^{* * *} \\
(3.73)\end{array}$ & $\begin{array}{l}1.414^{* * *} \\
(3.42)\end{array}$ & $\begin{array}{l}1.383^{* * *} \\
(3.28)\end{array}$ & $\begin{array}{l}1.331^{* * *} \\
(2.87)\end{array}$ & $\begin{array}{l}1.059^{* *} \\
(2.04)\end{array}$ \\
\hline UNGA Voting Similarity & & $\begin{array}{l}1.708^{* *} \\
(2.37)\end{array}$ & $\begin{array}{l}1.685^{* *} \\
(2.36)\end{array}$ & $\begin{array}{l}1.686^{* *} \\
(2.36)\end{array}$ & $\begin{array}{l}1.517^{* *} \\
(2.21)\end{array}$ \\
\hline ln.U.S. Military Aid & & & $\begin{array}{l}0.0272^{* *} \\
(2.20)\end{array}$ & $\begin{array}{l}0.0270^{* *} \\
(2.17)\end{array}$ & $\begin{array}{l}0.0231^{*} \\
(1.86)\end{array}$ \\
\hline Number of Terror & & & & $\begin{array}{l}0.000563 \\
(0.66)\end{array}$ & $\begin{array}{l}0.000141 \\
(0.19)\end{array}$ \\
\hline ln.Population & $\begin{array}{l}0.577^{* * *} \\
(3.51)\end{array}$ & $\begin{array}{l}0.540^{* * *} \\
(3.22)\end{array}$ & $\begin{array}{l}0.546^{* * *} \\
(3.34)\end{array}$ & $\begin{array}{l}0.537^{* * *} \\
(3.23)\end{array}$ & $\begin{array}{l}0.557^{* * *} \\
(3.47)\end{array}$ \\
\hline ln.GDP per capita & $\begin{array}{c}0.100 \\
(0.65)\end{array}$ & $\begin{array}{l}0.0251 \\
(0.16)\end{array}$ & $\begin{array}{l}0.0351 \\
(0.22)\end{array}$ & $\begin{array}{l}0.0333 \\
(0.21)\end{array}$ & $\begin{array}{c}0.104 \\
(0.62)\end{array}$ \\
\hline Polity & & & & & $\begin{array}{l}0.106^{* *} \\
(2.48)\end{array}$ \\
\hline Polity (FD) & $\begin{array}{l}0.0387^{*} \\
(1.97)\end{array}$ & $\begin{array}{l}0.0445^{*} \\
(1.93)\end{array}$ & $\begin{array}{l}0.0451^{* *} \\
(2.01)\end{array}$ & $\begin{array}{l}0.0454^{*} \\
(1.98)\end{array}$ & \\
\hline ln.Disaster Death & $\begin{array}{l}-0.000699 \\
(-0.04)\end{array}$ & $\begin{array}{l}0.00990 \\
(0.45)\end{array}$ & $\begin{array}{l}0.0111 \\
(0.51)\end{array}$ & $\begin{array}{l}0.0112 \\
(0.51)\end{array}$ & $\begin{array}{l}0.00958 \\
(0.44)\end{array}$ \\
\hline Constant & $\begin{array}{c}4.489 \\
(1.55)\end{array}$ & $\begin{array}{l}5.180^{*} \\
(1.77)\end{array}$ & $\begin{array}{l}4.817^{*} \\
(1.66)\end{array}$ & $\begin{array}{l}4.957^{*} \\
(1.68)\end{array}$ & $\begin{array}{c}3.926 \\
(1.34)\end{array}$ \\
\hline Observations & 994 & 862 & 862 & 862 & 863 \\
\hline$R^{2}$ & 0.781 & 0.794 & 0.795 & 0.795 & 0.795 \\
\hline adjusted $R^{2}$ & 0.780 & 0.792 & 0.793 & 0.793 & 0.793 \\
\hline$\rho$ & 0.767 & 0.739 & 0.733 & 0.733 & 0.731 \\
\hline Durbin-Watson (original) & 0.379 & 0.425 & 0.437 & 0.438 & 0.440 \\
\hline Durbin-Watson (transformed) & 1.804 & 1.739 & 1.743 & 1.744 & 1.751 \\
\hline
\end{tabular}

$t$ statistics in parentheses ${ }^{*} \mathrm{p}<0.1 ;{ }^{* *} \mathrm{p}<0.05 ;{ }^{* *} \mathrm{p}<0.01$ 
Table 3.1 displays the results from the Prais-Winsten models, estimating total regimecompatible democracy aid. I employ different models with different covariates. First of all, the $\rho$ statistics in all models are larger than .7, indicating that there is a significant serial correlation among regime-compatible democracy aid allocation.Second, the key independent variables in most models display similar effects on regime-compatible democracy aid allocation. From the baseline model to the most comprehensive models, the impact of the key independent variables is similar and statistically significant. However, terrorism does not appear to be related to the strategic choice of the U.S. on regime-compatible democracy aid allocation.

The results further suggest that the U.S. more likely to provide more regime-compatible democracy aid to the supportive authoritarian regimes (H1). First, the security interests of the U.S. on a recipient country affect regime-compatible democracy aid allocation. Model 4 indicates that Defense Alliance, UNGA Voting Similarity, and U.S. Military Aid share a significant positive relationship $(\mathrm{p}<.05)$ with total regime-compatible democracy aid. The U.S. is more likely to provide more regime-compatible democracy aid if an authoritarian regime is a defense alliance of the U.S., has higher voting similarity in UNGA with the U.S., or has more military aid from the U.S.

A recipient country with a defense alliance of the U.S. expects 133 percent more regime-compatible democracy aid than those without alliances. An authoritarian regime is more likely to have 16.86 percent more regime-compatible democracy aid for every .1 point increase in the UNGA voting similarity index. Finally, the U.S. increases 2.7 percent of regime-compatible democracy aid for every 1 percent increase in military aid. The 
results thus provide support for the argument that the U.S. makes a strategic decision on democracy aid allocation considering the relationship with a recipient country. The U.S. provides more acceptable democracy aid to authoritarian regimes that serve the U.S. security interests. It implies that the U.S. does not want to threaten supportive authoritarian regimes and not hurt the relationship with clientelistic recipient countries.

Second, however, economic interests with a recipient country are not crucial in determining U.S. regime-compatible democracy aid allocation. Total U.S. trade with recipient countries does not have a significant effect on the allocation of regime-compatible democracy aid in all models in Table 3.1. The results suggest that the U.S. does not consider the total trade with an authoritarian regime when distributing democracy aid. One reason for this result is that aid-receiving authoritarian regimes are not significant trade partners. The most prominent trade partners of the U.S. are democracies such as Canada, Mexico, UK, Japan, Germany, and South Korea. Thus, the U.S. may not be concerned with the total amount of trade conducted with recipient countries when they allocate democracy aid.

However, the percentage of crude oil import has a significant negative impact on regime-compatible democracy aid allocation. Oil imports have a significant negative relationship with regime-compatible democracy aid at 95 percent of the confidence interval. In Model 4, the U.S. increases 15.8 percent of regime-compatible democracy aid to a recipient country for every 1 percent increase in crude oil imports from the authoritarian regime. The result implies that the U.S. provides less regime-compatible democracy aid to crude oil import countries. However, this finding may arise because oil-exporting countries generally have less overall foreign assistance from the U.S. As a result, oil- 
exporting countries have a smaller amount of democracy aid compared to other countries. The results imply that the U.S. does not consider the economic interests of the recipient countries when they provide regime-compatible democracy aid.

Other alternative measurements show similar results to the previous studies. The population of recipient countries is a decisive factor of regime-compatible democracy aid. The U.S. is more likely to provide .5 percent more regime-compatible democracy aid when the population increases by 1 percent $(\mathrm{p}<.05)$. This result is related to a distribution pattern of donors that they consider the size of recipient countries in terms of population. Level of democracy also appears to share a positive relationship with regimecompatible democracy aid allocation even if they are statistically significant at 90 percent in some models (Model 1, 2, and 4). The U.S. considers the level of democracy in regimecompatible democracy aid allocation. However, economic conditions within a recipient country (GDP per capita) and natural disaster (Disaster Death) do not significantly affect U.S. regime-compatible democracy aid allocation. These findings imply that democracy aid allocation has different patterns with development aid or humanitarian aid allocations.

Table 3.2 displays Prais-Winsten estimations of ratio of regime-compatible democracy aid. I apply the same models with ratio variables to test how donors decide on the composition of democracy aid between regime-compatible and regime-incompatible types. The results are similar to the previous results of total regime-compatible democracy aid, even if some explanatory variables are not statistically significant at 95 percent of the confidence interval. This is because the transformation to ratio variables reduces the variations compared to total variables. 
Table 3.2: Prais-Winsten Estimations on Ratio of Regime-Compatible Democracy Aid

\begin{tabular}{|c|c|c|c|c|c|}
\hline & \multicolumn{5}{|c|}{ Dependent variable: } \\
\hline & \multicolumn{5}{|c|}{ Percentage of Regime-Compatible Democracy Aid of the U.S. } \\
\hline & (6) & (7) & (8) & (9) & $(10)$ \\
\hline Oil Import (\%) & $\begin{array}{l}-0.925^{* *} \\
(-2.00)\end{array}$ & $\begin{array}{l}-0.974^{* *} \\
(-2.17)\end{array}$ & $\begin{array}{l}-0.846^{* *} \\
(-2.06)\end{array}$ & $\begin{array}{l}-0.881^{* *} \\
(-2.17)\end{array}$ & $\begin{array}{l}-0.834^{* *} \\
(-2.22)\end{array}$ \\
\hline ln.Total Trade & $\begin{array}{c}0.295 \\
(0.20)\end{array}$ & $\begin{array}{c}0.790 \\
(0.54)\end{array}$ & $\begin{array}{c}0.539 \\
(0.37)\end{array}$ & $\begin{array}{c}0.525 \\
(0.36)\end{array}$ & $\begin{array}{c}0.300 \\
(0.21)\end{array}$ \\
\hline Defense Alliance & $\begin{array}{l}10.62^{* * *} \\
(4.00)\end{array}$ & $\begin{array}{l}10.03^{* * *} \\
(3.90)\end{array}$ & $\begin{array}{l}9.634^{* * *} \\
(3.78)\end{array}$ & $\begin{array}{l}10.58^{* * *} \\
(3.44)\end{array}$ & $\begin{array}{l}8.323^{* *} \\
(2.39)\end{array}$ \\
\hline UNGA Voting Similarity & & $\begin{array}{l}12.11^{*} \\
(1.93)\end{array}$ & $\begin{array}{l}11.57^{*} \\
(1.85)\end{array}$ & $\begin{array}{l}11.64^{*} \\
(1.87)\end{array}$ & $\begin{array}{c}9.648 \\
(1.53)\end{array}$ \\
\hline ln.U.S. Military Aid & & & $\begin{array}{c}0.378 \\
(1.66)\end{array}$ & $\begin{array}{c}0.382^{*} \\
(1.68)\end{array}$ & $\begin{array}{c}0.345 \\
(1.54)\end{array}$ \\
\hline Number of Terror & & & & $\begin{array}{l}-0.0109 \\
(-0.80)\end{array}$ & $\begin{array}{l}-0.0136 \\
(-0.97)\end{array}$ \\
\hline ln.Population & $\begin{array}{c}-0.994 \\
(-0.44)\end{array}$ & $\begin{array}{c}-1.392 \\
(-0.62)\end{array}$ & $\begin{array}{c}-1.372 \\
(-0.62)\end{array}$ & $\begin{array}{l}-1.215 \\
(-0.54)\end{array}$ & $\begin{array}{c}-1.092 \\
(-0.49)\end{array}$ \\
\hline $\ln$. GDP per capita & $\begin{array}{r}2.167 \\
(1.10)\end{array}$ & $\begin{array}{l}1.527 \\
(0.74)\end{array}$ & $\begin{array}{l}1.515 \\
(0.73)\end{array}$ & $\begin{array}{l}1.552 \\
(0.74)\end{array}$ & $\begin{array}{c}2.157 \\
(1.00)\end{array}$ \\
\hline Polity & & & & & $\begin{array}{c}0.969^{*} \\
(1.87)\end{array}$ \\
\hline Polity (FD) & $\begin{array}{c}-0.231 \\
(-0.56)\end{array}$ & $\begin{array}{c}-0.554 \\
(-1.53)\end{array}$ & $\begin{array}{c}-0.533 \\
(-1.50)\end{array}$ & $\begin{array}{c}-0.539 \\
(-1.51)\end{array}$ & \\
\hline ln.Disaster Death & $\begin{array}{c}0.236 \\
(0.79)\end{array}$ & $\begin{array}{c}0.264 \\
(0.86)\end{array}$ & $\begin{array}{c}0.284 \\
(0.91)\end{array}$ & $\begin{array}{c}0.286 \\
(0.91)\end{array}$ & $\begin{array}{c}0.272 \\
(0.86)\end{array}$ \\
\hline Constant & $\begin{array}{l}86.02^{* *} \\
(2.10)\end{array}$ & $\begin{array}{l}91.30^{* *} \\
(2.24) \\
\end{array}$ & $\begin{array}{l}88.16^{* *} \\
(2.18)\end{array}$ & $\begin{array}{l}85.47^{* *} \\
(2.07)\end{array}$ & $\begin{array}{l}77.24^{*} \\
(1.85) \\
\end{array}$ \\
\hline Observations & 1043 & 905 & 905 & 905 & 906 \\
\hline$R^{2}$ & 0.326 & 0.350 & 0.352 & 0.352 & 0.351 \\
\hline adjusted $R^{2}$ & 0.321 & 0.345 & 0.346 & 0.345 & 0.344 \\
\hline$\rho$ & 0.619 & 0.612 & 0.606 & 0.605 & 0.601 \\
\hline Durbin-Watson (original) & 0.614 & 0.628 & 0.636 & 0.640 & 0.644 \\
\hline Durbin-Watson (transformed) & 1.753 & 1.685 & 1.676 & 1.674 & 1.674 \\
\hline
\end{tabular}




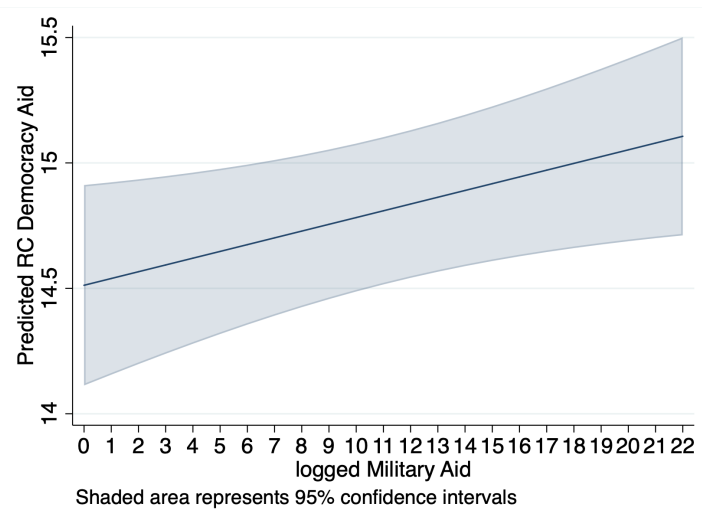

(a) Logged Military Aid

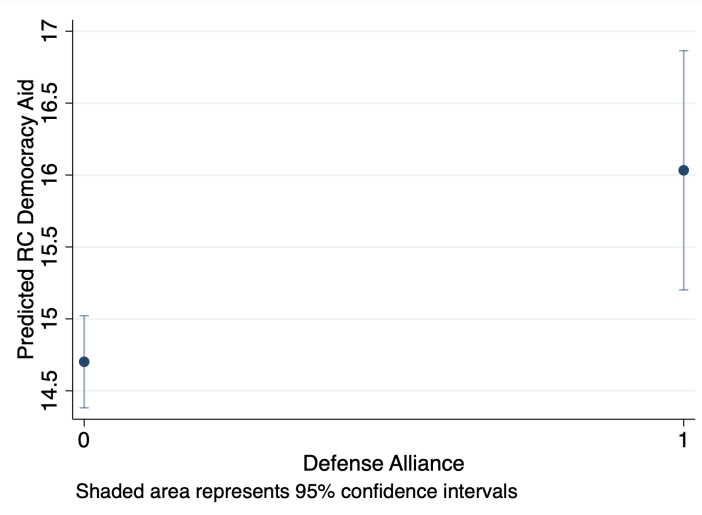

(b) Defense Alliance

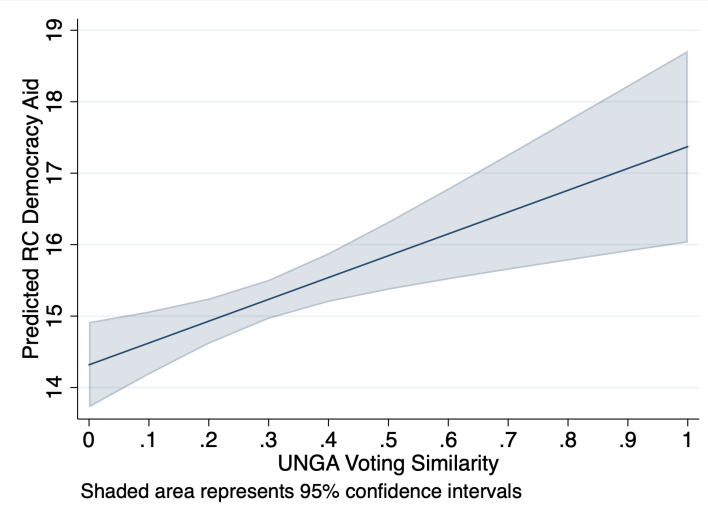

(c) UNGA Voting Similarity

Figure 3.3: Predicted Regime-compatible Democracy Aid

In these models, defense alliance has a positive effect on the ratio of regime-compatible democracy, and it is statistically significant $(\mathrm{p}<.05)$. The U.S. creates a democracy aid package with more regime-compatible types rather than regime-incompatible ones for their defense alliance. Also, UNGA voting similarity and U.S. military aid have a similar influence on regime-compatible democracy aid even though they are only statistically significant at 90 percent of the confidence interval. In these models, the share of oil import has a negative relationship with the ratio of regime-compatible democracy aid. It implies that the donors provide a democracy aid package with regime-incompatible democracy 
aid to oil exporting recipient countries even if they provide less foreign assistance to them. The results suggest that a decisive factor of regime-compatible democracy is the security interests of a recipient country. However, the U.S. does not consider the economic interests of a recipient county when they allocate democracy aid. This result supports Hypothesis 1 . Aid donors try to provide more favorable democracy aid to authoritarian regimes with a supportive relationship with the donors.

Figure 3.3 describes predicted regime-compatible democracy aid based on Model 4 in Table 3.1. Figure 3.3 (a) shows that a positive relationship between military aid and regime-compatible democracy aid even if there is no significant difference among levels of military aid at 95 percent of the confidence interval. However, the distribution pattern of U.S. regime-compatible democracy aid to defense alliances is different from those allocated to nonalliances. Figure 3.3 (b) describes that the predicted regime-compatible democracy aid to non-alliance is smaller than the aid to defense alliances, and both 95 percent of the confidence intervals are not overlapping. Similarly, the U.S. has significantly different patterns in democracy aid allocation by recipient countries' voting similarity in UNGA. In Figure 3.3 (c), recipient countries that have below .3 UNGA voting similarity index receive less regime-compatible democracy aid than recipient countries with a higher 7 UNGA voting similarity index. These results demonstrate that the U.S. makes strategic choices when allocating democracy aid. The U.S. has different democracy aid allocation patterns depending on the relationship with recipient countries. They provide more regime-compatible democracy aid to their defense alliances or authoritarian regimes that show compliance with the U.S. foreign policy in UNGA. 
The empirical findings demonstrate that strategic choices made by the U.S. affects patterns of democracy aid allocation to authoritarian regimes in recipient countries. The U.S. provides more regime-compatible democracy aid to authoritarian regimes within a clientelistic relationship with the U.S. The results suggest that the U.S. is more likely to provide more regime-compatible democracy aid to authoritarian regimes if they play party to a defense alliance, recipient of U.S. military aid, or have compliance with the U.S. in UNGA. They do not want to threaten or endanger their client countries with democracy aid. Therefore, the U.S. creates democracy aid packages with more regime-compatible ones. Compared to regime-incompatible democracy aid, regime-compatible democracy aid has similar characteristics with extra resources to authoritarian regimes.

\subsection{Conclusion}

The motivation of democracy aid is neither fully selfish nor selfless. Donors have multiple foreign policy goals, and they shape different motivations of democracy aid, such as normative commitment toward democracy, security and economic interests, and characteristics of a recipient country. The complexity of motivations makes donors practice different tactics on democracy aid allocation. If an authoritarian regime is important to donors' security or economic interests, donors try to provide democracy aid to stabilize the relationship with the recipient country. I argue that a strategic choice of donors can change the composition of democracy aid as well as its volume.

In this chapter, I test my argument using the U.S. case. I want to remark on two significant empirical findings. First, the U.S. has a strategic choice on democracy aid allocation to authoritarian regimes. Democracy aid policy is not created in a vacuum. As 
a part of U.S. foreign policy, the U.S. makes a strategic decision on democracy aid allocation. They try to provide different democracy aid packages to achieve multiple foreign policy goals. The empirical results support that the U.S. is more likely to provide more regime-compatible democracy aid to authoritarian regimes that play party to defense alliances, are large military aid recipients, or have higher UNGA voting similarities. The result implies that the U.S. provides different democracy aid packages depending on the relationship with recipient countries. If an authoritarian regime is important for U.S. security interests, the U.S. increases regime-compatible democracy aid to give more favor to the authoritarian regime. The U.S. does not want to threaten the authoritarian regime or disrupt a relationship via disputes over democracy aid.

Second, the U.S. is concerned with security interests more than economic interests in democracy aid allocation. Only security interest variables such as defense alliance, UNGA voting similarity, and military aid have a positive relationship with regime-compatible democracy aid. Total trade between the U.S. and a recipient country does not have a significant impact on regime-compatible democracy aid allocation. Furthermore, the share of crude oil import has a negative relationship with democracy aid allocation. The U.S. has small economic concerns with these authoritarian regimes because they are not the primary economic partners of the U.S. Additionally, the U.S. provides a relatively small amount of foreign assistance to oil-exporting countries than others. It implies that the U.S. approaches democracy aid allocation from political or security perspectives.

The findings present two implications with regard to patterns of Western democracy aid allocation. First, donors make strategic decisions regarding democracy aid allocation. 
Donors have multiple motivations for democracy aid allocation. Although Western donors have a normative commitment to democracy promotion, donors cannot be aggressive proponents of democracy. They must consider security or economic interests with a recipient country. This incentivizes Western donors to create different democracy aid packages for authoritarian regimes. Furthermore, donors are more likely to provide regime-compatible democracy aid to authoritarian regimes if donors want to support incumbents and acquire more concessions from them by providing favorable democracy aid.

Second, the results have implications for the effectiveness of democracy aid. There is a conventional argument on democracy aid that whether democracy aid can promote democratization in authoritarian regimes. Although previous literature focused on the relationship between the volume of democracy and a democratic transition in authoritarian regimes, I argue that the strategic choices of donors can make democracy aid ineffective. Donors can adjust the quality of democracy aid consisting of a democracy aid package with regime-compatible democracy. Regime-compatible democracy aid is similar to the extra resource to authoritarian regimes so that they are ineffective in breakdown authoritarian regimes or stimulate democratic transition. Therefore, the volume of democracy aid is important for the effectiveness of democracy aid, but the quality of democracy aid is also vital for the effectiveness. 


\section{Chapter 4}

\section{The Demand Side: Recipient Influence on Democracy Aid Allocation}

In 2015, Uhuru Kenyatta, the president of Kenya, encouraged other African leaders to stop receiving foreign aid. ${ }^{1} \mathrm{He}$ condemned foreign aid structures that come with unacceptable terms and conditions that preclude development in recipient countries. The Kenyan government later dismissed Kenyatta's comments as the president's personal opinion, stating that those comments did not represent the actual foreign policy of Kenya. While it is unusual for a national leader in a recipient nation to complain about foreign aid, this case gives illustrates that foreign aid can elicit different responses. Recipients may see foreign aid as an extra resource as well as an external threat. The possibility of different reactions implies that recipient governments may have an ambivalent attitude toward foreign aid, depending on its characteristics.

Authoritarian regimes have a strong preference for democracy aid when Western donors target vulnerable institutions within the regime. Authoritarian regimes have low levels of legitimacy, so they are more cautious about external intervention. As discussed in Chapter 2, authoritarian regimes maintain political power by utilizing different insti-

\footnotetext{
${ }^{1}$ BBC, 6.12.2015. "Kenya's Uhuru Kenyatta urges Africa to give up aid," https://www.bbc.com/news/ world-africa-33108716 (Retrieved: 6.25.2021)
} 
tutional ground and survival mechanisms. Some authoritarian regimes even adopt democratic institutions, such as elections or political party systems, to support their rule. They may also apply different survival tactics such as co-optation or repression depending on their political capacity or political circumstances. From the authoritarian perspective then, we can recognize two types of democracy aid: regime-compatible democracy aid and regime-incompatible democracy aid. Authoritarian regimes naturally prefer to increase regime compatible democracy aid and reduce regime-incompatible democracy aid. Authoritarian regimes are particularly willing to increase regime-compatible democracy aid if they face domestic political threats.

Although donors may allocate foreign aid however they see fit, recipient governments indicate their preferences during foreign aid allocation negotiations. Donors and recipient countries need to decide details of aid amounts, aid programs, and delivery channels to maximize their interests in foreign aid allocation. These negotiations are also a bargaining process to have a credible commitment to foreign aid allocation. Donors need to have recipient commitment on aid allocation during the negotiation. Donors are necessary to have credible consent from the recipient government because the recipient government has exclusive jurisdiction within the state as a sovereign state. They cannot achieve foreign aid goals without administrative assistance of recipient governments, government reforms, or enacting a new law for a legal ground of foreign aid activities. Recipient governments also want to have a credible commitment from donors on consistent and predictable foreign aid allocation (Swedlund 2017).

In foreign aid allocation negotiations, donors have superiority over recipient coun- 
tries. Donors are usually developed strong states while recipient countries are undeveloped weak states so that donors have high leverage over their recipient countries. Furthermore, the nature of foreign aid is an extra resource or gift to recipient countries. Donors may consider foreign aid as external interference in the domestic affair, but recipient governments may also consider it an opportunity to assuage budget constraints (Collier 2006). The willingness to accept foreign aid of recipient countries is greater than the willingness to provide foreign aid for donors.

However, recipient countries have different bargaining powers over donors on foreign aid allocation. Recipient governments also have a preference on foreign aid, and they can reflect their preference if they have bargaining power over the donors (Humphrey \& Michaelowa 2013, Wang 2016). There are various factors involves in the recipient countries' bargaining power. The presence of alternative donors like China, extra revenues from natural resources, and aid dependency can foster recipient bargaining power. However, considering the characteristics of foreign aid, a significant factor of the recipients' bargaining power is donors' interests in a recipient country. Recipient countries can win a concession from foreign aid allocation if donor nations view the recipient countries as essential for security or economic interests. The interests of donors make donors establish a clientelistic relationship with a recipient country. Donors are more likely to provide more favorable foreign aid to recipient countries in clientelistic relationship to make recipient countries serve donors' interests.

Donors have a similar strategy in democracy aid allocation. Remarkably, unlike development aid and humanitarian aid, democracy aid can be an inferior good to author- 
itarian regimes because it can endanger the political survival of authoritarian regimes. Democracy aid aims to promote democracy promotion in recipient countries so that authoritarian regimes can perceive democracy aid as a threat to their political survival rather than a gift. As explained in Chapter 2, authoritarian regimes have different preferences on democracy aid subtypes. Authoritarian regimes have a divergent perception of democracy aid subtypes depending on survival mechanisms and institutional characteristics: regimecompatible democracy and regime-incompatible democracy aid. Therefore, authoritarian regimes try to expert bargaining power to increase regime-compatible democracy aid and reduce regime-incompatible democracy aid during democracy aid allocation negotiations. Particularly, if authoritarian regimes face more political challenges within the state, they have more demand for minimizing external threats and maximizing political opportunity from democracy aid. Authoritarian regimes exert leverage over the donors to have more regime-compatible democracy aid.

In this chapter, I examine the recipient's influence on democracy aid allocation. I test how authoritarian regimes influence democracy aid composition along with donor/recipient relationships. I test hypotheses 2 and 2a with U.S. democracy aid allocation to authoritarian regimes from 1990 to 2013. Based on the findings in Chapter 3, I create a donorrecipient relationship variable for the U.S. democracy aid allocation and test how the relationship and domestic political instability affect the democracy aid allocation patterns. My findings suggest that U.S. democracy aid allocations to authoritarian regimes have a divergent pattern depending on a donor-recipient relationship when authoritarian regimes are confronted with more domestic threats for political survival. 


\subsection{Research Design}

To test my hypotheses, I develop a dataset that includes U.S. democracy aid to authoritarian regimes from 1990 to 2013. The dataset focuses on the authoritarian regimes in U.S. democracy aid recipient countries because I focus on the differences between authoritarian regimes. There are 101 recipient countries in the dataset. I focus on the post-Cold War era to restrict security bias. During the Cold War, security concerns with the Soviet Union made donors distort democracy aid allocation. I do not include small island countries to reduce bias from outliers.

\subsubsection{Dependent Variables: Democracy Aid}

I apply two dependent variables to test my hypotheses: a total of regime-compatible democracy aid and a ratio of regime-compatible democracy aid. I operationalize two variables based on the different democracy aid subtypes given to authoritarian regimes. As previously mentioned in Chapter 2, recipient countries have different attitudes on democracy aid subtypes depending on their domestic conditions. For authoritarian leaders in recipient countries, the primary goal is political survival. They have different acceptability to democracy aid subtypes due to their institutional background and the level of legitimacy. Authoritarian leaders are willing to have democracy aid if they perceive that it is not harmful to their political survival. However, if authoritarian regimes recognize democracy aid as an external threat to their regime stability, they may not accept the aid

To calculate regime-compatible democracy aid, I extract U.S. democracy aid data from AidData 3.1 (Tierney et al. 2011). I operationalize democracy aid using aid projects 
that are belong to the civil society and the government sector (DAC 5 Sector 151) in the OECD DAC purpose codes following the previous studies. I categorize democracy aid into eight subtypes along with their targeted institutions in recipient countries: 1) Governance, 2) Judiciary, 3) Election, 4) Legislature and Political Party, 5) Media, 6) Civil Society, 7) Human Rights, and 8) Women's Right. ${ }^{2}$ Next, I decide the 'regime compatibility' of each subtype of democracy aid depending on the authoritarian regime types. In this study, I use Wahman, Teorell \& Hadenius's (2013) Authoritarian Regime Data (THW).

I create two types of regime-compatible democracy aid variables. First, I calculate the total of regime-compatible democracy aid. I add up all regime-compatible democracy aid types that a recipient country received from the U.S. in a year. I have a log transformation to compress the large scale. The second variable is the percentage of regime-compatible democracy aid. I calculate the rate from democracy aid total that a recipient country received from the U.S. in a year.

\subsubsection{Independent Variables: Political Instability}

The key independent variable here is political instability. However, it is hard to measure political instability in authoritarian regimes because it is latent in their political dynamics. It is hard to capture until there are remarkable events in an authoritarian regime, such as coup attempts, demonstrations, or protests. However, although there were noticeable events in an authoritarian regime, they still do not represent how much authoritarian leaders perceive political instability in their own regimes. Furthermore, they have limitations

\footnotetext{
${ }^{2}$ See Appendix B.
} 
in capturing the political process of how authoritarian regimes respond to threats.

I measure political instability using authoritarian regimes' repression level. Authoritarian regimes would increase repression in their country if they perceived threats from political rivals or civil society. A conventional view on authoritarian regimes argues that authoritarian regimes stay in power using several survival strategies such as co-optation, repression, and legitimacy (Gandhi \& Przeworski 2007, Gerschewski 2013, Knutsen, Nygård \& Wig 2017). Among the survival strategies, repression is a prominent mechanism and the most effective method at deterring threats from dissent groups and civil society in general. Authoritarian regimes lean on repression mechanisms if they cannot apply co-optation mechanisms (Frantz \& Kendall-Taylor 2014). Therefore, the level of repression in authoritarian regimes is more likely to reflect latent threats that authoritarian leadership perceives. Authoritarian leaders will increase repression if they face higher political instability in the country.

I use two proxies to measure repression in an authoritarian regime. The first measurement is civil society organization repression (CSO repression). I draw CSO repression data from V-Dem Dataset v11.1 (Coppedge et al. 2021). It is a 5-point continuous variable. 0 means there is no repression on civil society organizations, and 4 stands for several governments' repression to civil society. The second measurement is the level of political terror (Political Terror). I draw a measure of political terror from the Political Terror Score (PTS) (Gibney et al. 2020). Particularly, I use an index collected from Country Reports on Human Rights Practices drawn up by the U.S. Department of State. It is also a 5-point scale categorical variable. Higher scores stand for higher levels of political terror, abuse, 
or violations in a country. ${ }^{3}$

Another key independent variable is an indicator of the relationship between the U.S. and recipient countries. In Chapter 3, I measured the relationship based on the economic and security interest of the U.S. The findings in Chapter 3 demonstrate that donors give more regime-compatible democracy aid to authoritarian regimes. I defined a supportive relationship between the U.S. and recipient countries using U.S. security and economic interest in recipient countries. Three measurements of security interests-military aid, UNGA voting similarity, and Defense alliance—are statistically significant $(\mathrm{p}<.05)$.

In this chapter, I define the relationship of the U.S. with recipient countries based on military aid. It has an advantage of showing more dynamic strategic interests in the U.S. in the recipient country. The U.S. provides military assistance for partner states that are important to U.S. national security (Sullivan, Tessman \& Li 2011). Defense alliance is a good measure to capture an established relationship between the U.S. and recipient countries, but it cannot capture the varying interests of the U.S. The U.S. signed a mutual defense alliance with only a few countries after World War II. The U.S. established the current defense alliance between 1950 and 1960, and did not sign alliance treaties anymore. Therefore, the existing defense alliance is based on the security environment of the Cold War and is not a good measure for explaining the U.S. security interests in the post-Cold War era. Also, UNGA voting similarity is not a good measure for identifying substantial U.S. interests, even if voting compliance of recipient countries in UNGA can reflect the support of recipient countries to the U.S. policy. Furthermore, these resolutions

\footnotetext{
${ }^{3}$ Level 1 stands for the county under a secured rule of law, and torture is rare or exceptional. Level 3 stands for extensive political imprisonment; political murders may be common. Finally, level 5 means that murders, disappearances, and torture are a common part of life for the whole population.
} 
are not binding agreements. The U.S. may not have security concerns despite to UNGA voting behavior.

Military aid data is drawn from USAID Greenbook. I create a military aid dummy variable based on whether a recipient country received military aid from the U.S. each year. The U.S. is selective in its military aid allocation and provides most of the military aid to few countries. As a result, the distribution of military aid amount has right-skewed distribution. I transformed the military aid variable into a dummy variable to show how the donor-recipient relationship affects the democracy aid allocation more clearly. If military aid is larger than 2nd quantile threshold, I coded 1, otherwise $0 .{ }^{4} \mathrm{I}$ include interaction terms to test how recipient countries have different leverage over the U.S. on democracy aid depending on the donor-recipient relationship. I have tests with military aid $\times$ CSO repression and military aid $\times$ Political Terror.

The military aid data draw from USAID Greenbook. I create a military aid dummy variable based on whether a recipient country received military aid from the U.S. in a year. The U.S. is selective in military aid allocation and provides most of the military aid to few countries. As a result, the distribution of military aid amount has right-skewed distribution. I transformed the military aid variable as a dummy variable to show how the donor-recipient relationship affects the democracy aid allocation more clearly. If military aid is larger than 2 nd quantile, I coded 1 , otherwise $0 .{ }^{5} \mathrm{I}$ include interaction terms to test

\footnotetext{
${ }^{4}$ I also tested the same model with the original military aid variable and alternative dummy variable, which is based on the 3rd quantile threshold. You can find alternative models in Appendix D. The results of alternative models are similar to the main models.

${ }^{5}$ I also tested the same model with the original military aid variable and alternative dummy variable, which is based on the 3rd quantile value. You can find alternative models in Appendix D. The results of alternative models are similar to the main models.
} 
how recipient countries have different leverage over the U.S. on democracy aid depending on the donor-recipient relationship. I have tests with military aid $\times C S O$ repression and military aid $\times$ Political Terror.

\subsubsection{Control Variables}

I include several control variables following the previous studies to reflect alternative explanations of foreign aid allocation. I control for the level of governance of a recipient country (Governance). Donors consider the government capability in the recipient country when they allocate democracy aid (Winters \& Martinez 2015). I draw governance data from World Governance Indicators (WGI) dataset (Kaufmann \& Kraay 2020). WGI dataset measures six dimensions of governance: voice and accountability, political stability and absence of violence, government effectiveness, regulatory quality, rule of law, and control of corruption. WGI compiles different data sources such as surveys of citizens and firms, commercial business information providers, NGOs, and public sector organizations. It is a very similar process when foreign aid agencies in donor countries evaluate government capability. I construct Governance aggregating all six indicators following the previous research (Dietrich 2013, Dilorenzo 2018). Higher values stand for the higher quality of governance.

I control a variable Polity to control for a variance from the regime types of recipient country (Marshall \& Gurr 2020). I construct two kinds of polity measures: Polity is a measure that I transform Polity 2 to 10 point scale from 0 to 10 . Polity $(F D)$ is a measure of a difference Polity 2 score from the previous year. It is helpful to control for the level effect from regime type difference. I include Population and GDP per capita to control 
the size and economic status of recipient countries. I draw the data from the World Bank Development Indicators (World Bank 2021). Donors may provide more democracy aid to a recipient country with a larger population and lower economic development.

I include Civil Conflict based on a logic that a civil conflict prompts donors to provide more democracy aid to help them to solve a conflict in a more peaceful way or to support rebuilding afterward. I count the number of civil conflicts in a recipient country in a year (Civil Conflict). I use UCDP/PRIO Armed Conflict Dataset (Gleditsch et al. 2002). In a similar vein, I control the number of occurrences of natural disasters (Disaster). I draw disaster data from EMDAT-CRED. ${ }^{6}$ I calculate the natural log of the number of natural disasters in the recipient country in a given year.

\subsection{Empirical Results}

I apply fixed-effect models to test my hypotheses. Fixed effect models have the advantage to deal with unobserved time-constant effects on individuals or countries (Wooldridge 2016, 383). This chapter mainly focuses on the influence of recipients on democracy aid allocation. Fixed-effect models help to cancel out the bias from unobserved characteristics of recipient countries on democracy aid allocation. All models reject a null hypothesis of Hausman tests $(\mathrm{p}<.05)$ so that fixed-effect models are more appropriate to control the presence of subject-specific means.

Table 4.1 presents the result of fixed-effects models that test the effect of political stability and donor-recipient relationship on regime-compatible democracy aid alloca-

\footnotetext{
${ }^{6}$ Centre for Research on the Epidemiology of Disasters (CRED), Emergency Events Database (EMDAT), http://www.emdat.be/ (retrieved: 6.25.2021).
} 
Table 4.1: Fixed Effect Models with CSO Repression Measure

\begin{tabular}{|c|c|c|c|c|}
\hline & \multicolumn{4}{|c|}{ Dependent variable: Regime-Compatible Democracy Aid } \\
\hline & \multicolumn{2}{|c|}{ Total } & \multicolumn{2}{|c|}{ Ratio } \\
\hline & (1) & (2) & (3) & (4) \\
\hline Lagged $\mathrm{DV}_{t-1}$ & $\begin{array}{l}0.205^{* * *} \\
(0.038)\end{array}$ & $\begin{array}{l}0.208^{* * *} \\
(0.038)\end{array}$ & $\begin{array}{l}0.298^{* * *} \\
(0.037)\end{array}$ & $\begin{array}{c}0.297^{* * *} \\
(0.037)\end{array}$ \\
\hline Oil Import (\%) & $\begin{array}{c}-0.248^{* * *} \\
(0.090)\end{array}$ & $\begin{array}{c}-0.253^{* * *} \\
(0.091)\end{array}$ & $\begin{array}{c}0.199 \\
(0.689)\end{array}$ & $\begin{array}{c}0.178 \\
(0.691)\end{array}$ \\
\hline CSO Repression & $\begin{array}{c}-2.318^{* * *} \\
(0.528)\end{array}$ & $\begin{array}{c}-3.035^{* * *} \\
(0.498)\end{array}$ & $\begin{array}{c}-11.702^{* * *} \\
(4.068)\end{array}$ & $\begin{array}{c}-13.393^{* * *} \\
(3.793)\end{array}$ \\
\hline Military Aid (Dummy) & $\begin{array}{c}-0.163^{* *} \\
(0.064)\end{array}$ & $\begin{array}{c}-0.156^{* *} \\
(0.064)\end{array}$ & $\begin{array}{c}-1.222^{* *} \\
(0.493)\end{array}$ & $\begin{array}{c}-1.213^{* *} \\
(0.494)\end{array}$ \\
\hline Military Aid $\times$ CSO Repression & $\begin{array}{l}0.117^{* * *} \\
(0.028)\end{array}$ & $\begin{array}{l}0.120^{* * *} \\
(0.028)\end{array}$ & $\begin{array}{l}0.784^{* * *} \\
(0.216)\end{array}$ & $\begin{array}{c}0.788^{* * *} \\
(0.217)\end{array}$ \\
\hline Governance & $\begin{array}{c}-0.206 \\
(0.650)\end{array}$ & $\begin{array}{c}0.078 \\
(0.655)\end{array}$ & $\begin{array}{c}8.404^{*} \\
(5.058)\end{array}$ & $\begin{array}{c}8.981^{*} \\
(5.053)\end{array}$ \\
\hline Polity & $\begin{array}{l}0.389^{* * *} \\
(0.099)\end{array}$ & & $\begin{array}{c}0.855 \\
(0.768)\end{array}$ & \\
\hline Polity score (FD) & & $\begin{array}{c}0.092 \\
(0.062)\end{array}$ & & $\begin{array}{c}-0.055 \\
(0.473)\end{array}$ \\
\hline ln.Population & $\begin{array}{l}1.092^{* * *} \\
(0.325)\end{array}$ & $\begin{array}{l}1.039^{* * *} \\
(0.328)\end{array}$ & $\begin{array}{c}-0.351 \\
(2.511)\end{array}$ & $\begin{array}{c}-0.454 \\
(2.513)\end{array}$ \\
\hline ln.GDP per capita & $\begin{array}{c}-0.009 \\
(0.351)\end{array}$ & $\begin{array}{c}0.195 \\
(0.351)\end{array}$ & $\begin{array}{c}-8.650^{* * *} \\
(2.757)\end{array}$ & $\begin{array}{c}-8.158^{* * *} \\
(2.733)\end{array}$ \\
\hline ln.Disaster Death & $\begin{array}{c}0.037 \\
(0.070)\end{array}$ & $\begin{array}{c}0.030 \\
(0.070)\end{array}$ & $\begin{array}{c}0.199 \\
(0.539)\end{array}$ & $\begin{array}{c}0.162 \\
(0.540)\end{array}$ \\
\hline Civil War & $\begin{array}{c}-0.978 \\
(0.793)\end{array}$ & $\begin{array}{c}-0.839 \\
(0.801)\end{array}$ & $\begin{array}{c}-2.861 \\
(6.137)\end{array}$ & $\begin{array}{c}-2.488 \\
(6.142)\end{array}$ \\
\hline Observations & 772 & 771 & 772 & 771 \\
\hline $\mathrm{R}^{2}$ & 0.213 & 0.197 & 0.169 & 0.167 \\
\hline adjusted $\mathrm{R}^{2}$ & 0.097 & 0.079 & 0.046 & 0.044 \\
\hline
\end{tabular}


tion. I examine models on both the total and ratio of regime-compatible democracy aid. I use CSO repression for political stability measure, and Military Aid (dummy) measure a donor-recipient relationship whether a recipient country has a relationship relationship with the U.S. or not. Models in Table 4.1 present key independent variables-CSO repression, Military aid (Dummy), and their interaction term—are related to regime-compatible democracy aid, and they are statistically significant at $\mathrm{p}<.05$.

Model (1) and (2) in Table 4.1 show that a divergent allocation pattern of U.S. regimecompatible democracy aid depending on the donor-recipient relationship. Two columns are the same model with different polity score measures, and the results almost similar. In Model (2), one point increase in CSO Repression decreases regime-compatible democracy aid to authoritarian regimes that are not U.S. military aid recipients, and it is statistically significant at $\mathrm{p}<.05$. However, the interaction term (Military aid $\times$ CSO repression) is positively related to U.S. regime-compatible democracy aid, and it is statistically significant at $\mathrm{p}<.05$. The U.S. increases 130 percent of regime-compatible democracy aid to military aid recipients for every 1 point increase in CSO repression index.

The results correspond to my theoretical argument that an authoritarian regime wins a concession from donors on democracy aid allocation depending on whether the recipient country is a clientelistic state of the U.S. or not. Authoritarian regimes have different leverage over the U.S. on democracy aid allocation. The results show that an authoritarian regime with a clientelistic relationship with the U.S. receives more regime-compatible democracy aid from the U.S. when they become politically unstable. Conversely, nonclientelistic authoritarian regimes receive less regime-compatible democracy aid from the 
U.S. when they have higher political threats within the state. This finding suggests that the U.S. accommodates the needs of recipient countries in a clientelistic relationship while the U.S. takes advantage of a political crises in non-clientelistic states to promote democracy. The models with the ratio of regime-compatible democracy aid show more clearly how the U.S. changes the composition of democracy aid according to its donor-recipient relationship. Model (4) in Table 4.1 which is the same model with Model (2), shows more clearly that the U.S. democracy aid distribution pattern is divergent depending on the relationship with recipient countries. CSO Repression and the interaction (Military Aid $\times$ CSO Repression) reveal a divergent direction of effect, and they are statistically significant at a 95 percent confidence interval. The results show that donor-recipient relationships affect democracy aid program selection by the U.S.

When authoritarian regimes become unstable, the U.S. increases the ratio of regimecompatible democracy aid in a democracy aid package to clientelistic authoritarian regimes while they decrease the regime-compatible democracy aid to non-clientelistic authoritarian regimes. The results suggest that recipient countries have different bargaining power over donors during democracy aid allocation negotiations. If authoritarian regimes are important for donor interests, authoritarian regimes can exert more leverage over donors to provide more regime-compatible democracy aid for their political survival, and donors also have the willingness to accept the request to support their clientelistic authoritarian regimes. However, donors do not have the motivation to accommodate the demand of non-clientelistic authoritarian regimes. Donors are more likely to utilize a domestic crisis as an opportunity for democracy promotion. 
Table 4.2: Fixed Effect Models with Political Terror Measure

\begin{tabular}{|c|c|c|c|c|}
\hline & \multicolumn{4}{|c|}{ Dependent variable: Regime-Compatible Democracy Aid } \\
\hline & \multicolumn{2}{|c|}{ Total } & \multicolumn{2}{|c|}{ Ratio } \\
\hline & $(5)$ & $(6)$ & (7) & $(8)$ \\
\hline Lagged $\mathrm{DV}_{t-1}$ & $\begin{array}{l}0.199^{* * *} \\
(0.038)\end{array}$ & $\begin{array}{l}0.213^{* * *} \\
(0.039)\end{array}$ & $\begin{array}{l}0.296^{* * *} \\
(0.038)\end{array}$ & $\begin{array}{l}0.294^{* * *} \\
(0.038)\end{array}$ \\
\hline Oil Import (\%) & $\begin{array}{c}-0.289^{* * *} \\
(0.091)\end{array}$ & $\begin{array}{c}-0.308^{* * *} \\
(0.093)\end{array}$ & $\begin{array}{c}0.026 \\
(0.695)\end{array}$ & $\begin{array}{c}-0.036 \\
(0.696)\end{array}$ \\
\hline Political Terror & $\begin{array}{c}-1.466^{* * *} \\
(0.382)\end{array}$ & $\begin{array}{c}-1.513^{* * *} \\
(0.391)\end{array}$ & $\begin{array}{c}-8.071^{* * *} \\
(2.976)\end{array}$ & $\begin{array}{c}-8.224^{* * *} \\
(2.982)\end{array}$ \\
\hline Military Aid (Dummy) & $\begin{array}{c}-0.331^{* * *} \\
(0.094)\end{array}$ & $\begin{array}{c}-0.320^{* * *} \\
(0.096)\end{array}$ & $\begin{array}{c}-1.602^{* *} \\
(0.733)\end{array}$ & $\begin{array}{c}-1.601^{* *} \\
(0.735)\end{array}$ \\
\hline Military Aid $\times$ Political Terror & $\begin{array}{l}0.119^{* * *} \\
(0.026)\end{array}$ & $\begin{array}{l}0.123^{* * *} \\
(0.026)\end{array}$ & $\begin{array}{l}0.570^{* * *} \\
(0.200)\end{array}$ & $\begin{array}{l}0.583^{* * *} \\
(0.200)\end{array}$ \\
\hline Governance & $\begin{array}{c}0.390 \\
(0.669)\end{array}$ & $\begin{array}{c}1.188^{*} \\
(0.670)\end{array}$ & $\begin{array}{c}10.232^{*} \\
(5.221)\end{array}$ & $\begin{array}{l}11.880^{* *} \\
(5.121)\end{array}$ \\
\hline Polity & $\begin{array}{l}0.482^{* * *} \\
(0.085)\end{array}$ & & $\begin{array}{c}0.964 \\
(0.660)\end{array}$ & \\
\hline Polity (FD) & & $\begin{array}{c}0.112^{*} \\
(0.062)\end{array}$ & & $\begin{array}{c}-0.046 \\
(0.473)\end{array}$ \\
\hline ln.Population & $\begin{array}{l}1.050^{* * *} \\
(0.325)\end{array}$ & $\begin{array}{l}1.038^{* * *} \\
(0.332)\end{array}$ & $\begin{array}{c}-0.795 \\
(2.518)\end{array}$ & $\begin{array}{c}-0.785 \\
(2.524)\end{array}$ \\
\hline ln.GDP per capita & $\begin{array}{c}-0.291 \\
(0.335)\end{array}$ & $\begin{array}{c}-0.269 \\
(0.343)\end{array}$ & $\begin{array}{c}-9.584^{* * *} \\
(2.647)\end{array}$ & $\begin{array}{c}-9.536^{* * *} \\
(2.655)\end{array}$ \\
\hline ln.Disaster Death & $\begin{array}{c}0.026 \\
(0.070)\end{array}$ & $\begin{array}{c}0.012 \\
(0.071)\end{array}$ & $\begin{array}{c}0.135 \\
(0.541)\end{array}$ & $\begin{array}{c}0.084 \\
(0.542)\end{array}$ \\
\hline Civil War & $\begin{array}{r}-1.086 \\
(0.787)\end{array}$ & $\begin{array}{r}-1.145 \\
(0.805)\end{array}$ & $\begin{array}{r}-2.546 \\
(6.115)\end{array}$ & $\begin{array}{c}-2.616 \\
(6.133)\end{array}$ \\
\hline Observations & 772 & 771 & 772 & 771 \\
\hline $\mathrm{R}^{2}$ & 0.213 & 0.179 & 0.163 & 0.160 \\
\hline adjusted $\mathrm{R}^{2}$ & 0.096 & 0.058 & 0.039 & 0.036 \\
\hline
\end{tabular}


The results also show that authoritarian regimes that have military assistance from the U.S. is more likely to have less regime-compatible democracy aid than authoritarian regimes that are not military assistance recipients. In Model (2) and (4), Military Aid is negatively related to regime-compatible democracy aid, and it is statistically significant at 95 percent of the confidence interval $(\mathrm{p}<.05)$. On average, the U.S. is more likely to provide less regime-compatible democracy aid to the clientelistic states than neutral or antagonistic states if recipient are fully stable. The result represents that the U.S. tries to provide democracy aid to serve the normative goal of each aid program if a clientelistic country is politically stable. The U.S. has a low necessity to support the clientelistic country with regime-compatible democracy. Clientelistic countries may not be necessary to exert leverage over the U.S. to change democracy aid packages because they have enough political capacity to accept it.

To ensure the robustness of my findings, I also test my theoretical arguments with another measure for political instability in authoritarian regimes. Table 4.2 represents alternative fixed-effect models leveraging Political Terror. The Political Terror score measures more direct political violence against civilians or political dissents while CSO Repression focuses government activities on restraining civil society activities. Authoritarian regimes are more likely to lean on violence against dissent groups when facing more challenges to the regime. The key independent variables in these models have almost similar results with the previous models. Political Terror, Military Aid, the interaction term (Military aid $\times$ Political Terror) have similar impact to the regime-compatible democracy with the models in Table 4.1, and they are statistically significant at the 95 percent confidence in- 
terval. This result also supports that the U.S. accede to the demands of client states when the U.S. allocates democracy aid. The U.S. increases regime-compatible democracy aid to support clientelistic authoritarian regimes when faced with the threat of domestic challenges to the regime.

\subsection{Democracy aid to Cambodia and Myanmar}

U.S. democracy aid allocations to Cambodia and Myanmar have divergent patterns. The two countries are similar in geopolitical and economic conditions, but the U.S. has established different relationships with each state, and this has affected democracy aid allocation. Both countries are not a formal defense alliance of the U.S., but Cambodia was one of the largest U.S. military aid recipients between 2003 and 2013, while Myanmar received little military aid from the U.S.

Cambodia and Myanmar are not important states for U.S. economic interests. As a member of the Association of Southeast Asian Nations (ASEAN), they have economic importance to the U.S., but both countries are neither important trade partners nor oil export countries. Myanmar is around four times larger in territory and population, but they have similar economic levels of GDP per capita. They are one of the least developed countries (LDCs), which are developing countries with lower human rights index according to the UN, higher poverty rate, and economic vulnerability. Cambodia and Myanmar are more likely to have higher needs for foreign assistance because of low socioeconomic conditions.

U.S. relations with Myanmar are antagonistic after the military junta quashed the popular protest against the military government in 1988. The U.S. has sanctioned Myanmar 


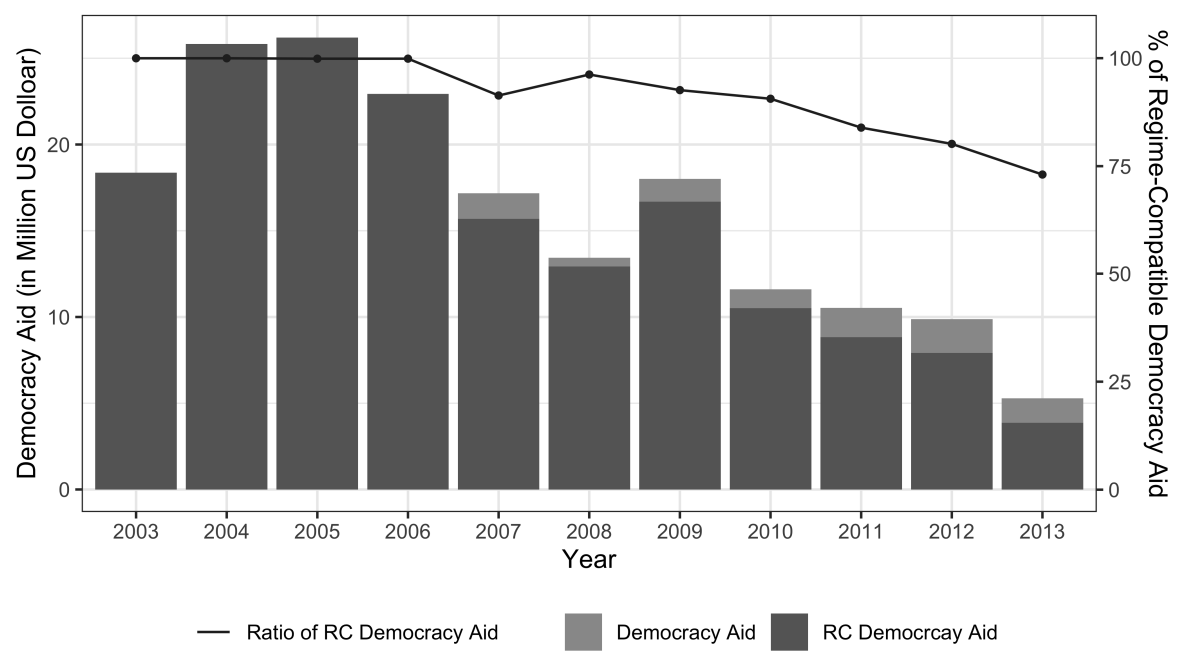

(a) Cambodia

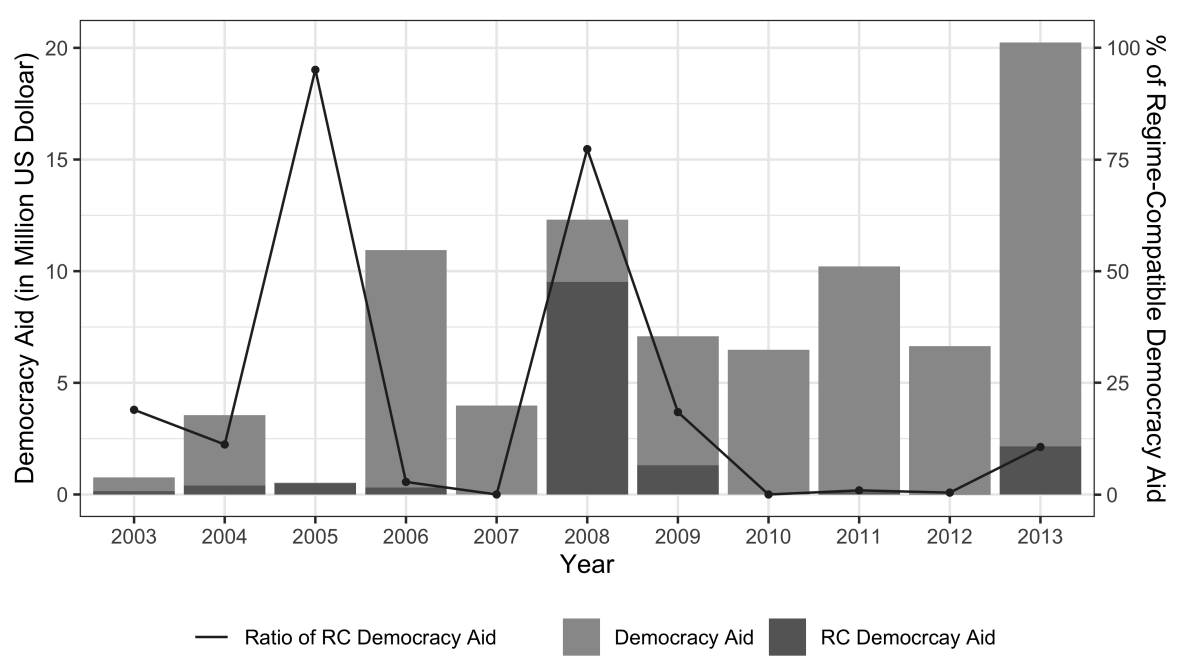

(b) Myanmar

Figure 4.1: Democracy Aid Allocation (2003-2013)

Source: AidData 3.1 (Tierney et al. 2011) 
because of a human rights issue since 1988. A symbolic example that shows the attitude of the U.S. toward Myanmar is the U.S.'s disapproval to recognize Myanmar as the national title. In 1989, the ruling military junta changed the state's name from Burma to Myanmar, but the U.S. has not recognized this change. Although the UN and most countries recognized Myanmar, the U.S. government continues to use Burma officially. One important reason for a sour relationship between the U.S. and Myanmar is the close relationship between Myanmar and China. After World War II, the military government leaned to the China (Martin 2013). Myanmar was the first country to recognize China among nonCommunist countries. After the U.S. sanctioned Myanmar because of the Human rights issue in 1988, China became the most prominent supporter of Myanmar. China provides foreign assistance, including military aid to maintain close relations with Myanmar after the international community, including the U.S., abandoned them.

Compared to Myanmar, the U.S. has clientelistic or neutral relations with Cambodia since the 2000s. After the end of the Cambodian-Vietnamese War in 1991, Cambodia tried to resolve Western concerns about their country. They attempted to conduct elections, improve human rights conditions. Although a military coup d'ètat in 1997 strained U.S.-Cambodia relations, new security issues in the region demanded a closer U.S. relationship with Cambodia. The policy priorities of the U.S. for Southeast Asia have grown more important since China has emerged as a new challenger during the 2000s. This dynamic situation increases the U.S.'s need to rebalance the security interests in the region. Therefore, Cambodian effort for human rights issues or liberalization is a reasonable justification for reconstructing the U.S.-Cambodia relationship. The U.S. changed its attitude 
toward Cambodia and became more supportive during the 2000s.

Figure 4.1 describes different U.S. democracy aid allocation patterns to Cambodia and Myanmar between 2003 and 2013. First of all, Cambodia generally has more democracy aid from the U.S. than Myanmar. The U.S. provided more than 20 million dollars between 2004 and 2006 for democracy aid while Myanmar had less than 5 million dollars during the same period. Also, the U.S. created the most democracy aid for Cambodia with regime-compatible programs. More than 75 percent of democracy was regime-compatible aid during this period. However, democracy aid for Myanmar has different patterns that the percentage of regime-compatible democracy aid is usually less than 5 percent. In 2005 , the portion was closed to 95 percent, but the total of democracy aid is diminutive.

Th

The democracy aid allocation patterns of the two countries describe that how a recipient country can utilize the donor-recipient relationship in democracy aid allocation. Although it is not clearly shown that marginal changes of regime-compatible democracy aid allocation pattern, it describes that donors are more likely to make way for recipient countries to have more regime-compatible democracy aid. If the U.S. wants to make a good relationship with recipient countries because of their interests, they even change the composition of democracy aid programs to help recipient countries even if they are an authoritarian regime.

\subsection{Conclusion}

Aid allocation is often thought of as a unilateral decision made by donors. From this perspective, the willingness and decision of donors are the decisive factors of aid alloca- 
tion because recipient countries are always willing to have all aid from donors if donors want to provide it. Theoretically, however, aid allocation is a close bargaining process between donors and recipient countries. As part of donors' foreign policy, foreign aid has ambivalent characteristics between extra resource and external intervention, and donors and recipient countries are necessary to negotiate the amount of aid, aid programs, and delivery mechanisms. Therefore, although donors have priority on foreign aid allocation, recipient countries can reflect their preference on foreign aid depending on bargaining power over donors.

In this chapter, I examine how recipient bargaining power can change the shape of foreign aid using the U.S. democracy aid to authoritarian regimes. As I argued in Chapter 2, Authoritarian regimes have different attitudes toward democracy aid programs depending on their institutional characteristics and survival mechanisms. Also, donors could have divergent motivations on democracy aid allocation. They have a normative commitment to democracy promotion but also want to utilize democracy aid for primary foreign policy goals such as economic and security interests. These complicated concerns and interests on democracy aid interact in democracy aid allocation.

The empirical findings in this chapter support that authoritarian regimes can have different democracy aid from the U.S. depending on their bargaining power over the U.S. If authoritarian regimes are important for U.S. security interests, the U.S. may construct a supportive relationship with the authoritarian regime and make more concessions to the authoritarian regime. Particularly, when authoritarian regimes face domestic political threats, the U.S. is more likely to accommodate the needs of authoritarian regimes for 
political survival if the U.S has a clientelistic relation with the recipient country. However, donors are more likely to utilize domestic unrest in the non-clientelistic authoritarian regime as a chance for democracy promotion. This is because increases regimeincompatible democracy aid in these recipient countries.

We can find three implications from the empirical results. First, the domestic condition of recipient countries is important for democracy aid allocation. Authoritarian regimes have different attitudes toward democracy aid depending on political survival mechanisms. They have different evaluation on democracy aid targeting various political or social institutions between an opportunity or an external threat depending on the political capacity. The ambivalent character of democracy aid gives an answer to why authoritarian regimes have had democracy aid that seems like a 'poisoned chalice' for their political survival. Some democracy aid cannot threaten some authoritarian regimes depending on institutional characteristics and survival mechanisms, and it is why authoritarian regimes have democracy aid.

The second implication is that the donor-recipient relationship is an essential factor in democracy aid allocation. Donors have a normative commitment to democracy promotion, but they do not allocate democracy aid only for the commitment. Different policy interests are involved in democracy aid allocation, and donors have a different priority on democracy aid depending on donors' interests. Also, the multiple motivations of donors on democracy aid make recipient countries can exert leverage over donors on democracy aid allocation. It implies that we must recognize the democracy aid allocation process is strategic interaction between donors and recipient countries. 
Finally, the theoretical arguments and findings give an implication on the effectiveness of foreign aid. Why can democracy aid not promote democracy? Previous studies provide various intuitions, but this research also provides one possible answer. The result suggests that both the quantity of democracy aid and the quality of democracy aid are important for effectiveness. The amount of democracy aid is important, but a composition of aid is also important. Although donors provide a large amount of democracy aid, the effort may not be effective for democracy promotion if donors fail to target an appropriate object. To evaluate democracy aid effectiveness, we need to look up the composition of democracy aid packages.

I also want to point out the limitations for further research on democracy aid. First, one big challenge is that how to capture the relationship between donors and recipient countries. Donors and recipient countries usually do not bring their interests to the fore of foreign policy. Countries establish various formal relations with other countries, but they have a limitation to capture the substantive interests of countries. Furthermore, countries establish multiple ties with other countries for different reasons. In this study, I focus on U.S. democracy aid, but it is necessary to consider how to measure the relationship between donors and recipients.

Secondly, we need to think about how we can capture the changes in aid allocation more precisely. The margins of democracy aid change are hard to capture. The changes of democracy aid allocation patterns can have random patterns because various motivations involve democracy aid allocation. It is particularly hard to capture the margin changes of democracy aid triggered by a policy change. Also, donors generally fund 
multi-year aid projects. Once donors decide to fund an aid project in a year, this decision carries over into future periods. Therefore, the aid allocation patterns may not reflect the immediate interests of donors. Multiple aid agency involvement also can reinforce this problem. Donors have multiple foreign aid agencies. For instance, in the U.S., USAID, the State Department, and the Department of Defense distribute fund democracy aid programs (Carothers 2009b). It makes donors cannot to have consistent democracy aid allocation patterns. Previous studies discuss various intuitions, but this research also provides one possible answer. 


\section{Chapter 5}

\section{Conclusion}

The end of the Cold War was a monumental moment in international relations. Countries have faced a new global security environment, and it provided an opportunity for Western donors to expand democracy promotion policy. Western donors could use foreign aid more actively to promote democracy and indeed assigned more aid for these purposes . For the past three decades, the allocation patterns of democracy aid have been exhibiting an increasing trend. Democracy aid, at the same time, has been expanded in terms of its programs. Western donors developed various democracy aid programs to support core institutions, norms, and values of democracy, including programs for supporting free and fair elections and political parties, civil society, human rights, and women's rights. Donors can more precisely calibrate domestic conditions in recipient countries and deliver customized programs to them.

However, although the dissolution of the Cold War provided more room for democracy promotion policy, democracy promotion is still not the primary goal for many Western countries. Compared to foreign policy goals for security and economic interests, democracy promotion policy has been a low priority. Indeed, these policies have been treated as an intermediate goal and even a justification for self-interest-seeking acts. Be- 
cause of the low priority of democracy promotion policy, multiple motivations and interests are often involved in the development of these policies. This is a primary reason that the allocation and the effectiveness of democracy aid show irregular patterns in various research (de Zeeuw 2005, Carothers 2009b). Therefore, an effective democratic aid allocation mechanism needs to consider how these various interests and motivations of donors are involved.

A unique trait of democracy aid also contributes to democratic aid allocation patterns. As I discussed in Chapter 2, democracy aid has two characteristics to authoritarian regimes: an opportunity and an external threat. On the one hand, authoritarian regimes consider democratic aid an opportunity for extra resources in that donors provide financial support, supplies, and technical assistance. On the other hand, authoritarian regimes perceive democratic aid as a threat to their political survival in that democracy aid can increase demands for democracy and promote democratic norms, practices, and values. It can threaten the survival of authoritarian leaders in power. The ambivalent characteristics of democracy aid make donors and recipient countries have more strategic choices on democracy aid allocation. Therefore, democracy aid has different features and impacts on authoritarian regimes, even if they have the same amount of democracy aid from the same donors.

To conceptualize the divergent characteristics of democracy aid, I define and categorize democracy aid into two different types: regime-compatible and regime-incompatible democracy aid. The concept of 'regime compatibility' is decided by whether a type of democracy aid can threaten authoritarian regimes or not. The vulnerability deriving 
from low legitimacy and institutional weakness makes authoritarian regimes to consider democracy aid a threat. Moreover, authoritarian leaders in recipient countries have various evaluations regarding democracy aid because of different institutional traits and survival mechanisms. I determine the regime compatibility of eight types of democracy aid, depending on the types of authoritarian regimes.

In this dissertation, I consider democracy aid allocation as a bargaining process between donors and recipient countries. I assume that the two parties-i.e., donors and recipient countries - have to negotiate for democracy aid allocation because donors must have consent on activities in recipient countries. Although donors are the primary party in aid allocation, recipient countries can have leverage on democracy aid allocation during this negotiation process. However, the leverage of authoritarian regimes depends upon the concession of donors. Authoritarian regimes can have more leverage if they are important to donors' security and/or economic interests. Donors are more likely to provide more favorable democracy aid to authoritarian regimes reflecting authoritarian regimes' needs. Donors do not want to disrupt the stability of the status quo if a current government is necessary for their national interests, regardless of the regime types of recipient countries.

The main argument of my dissertation is that the strategic choices of donors and recipient countries change the shape and dynamics of democracy aid. Between regimecompatible and regime-incompatible democracy aid, donors have a divergent choice depending on their interests in recipient countries. If an authoritarian regime is important for their security and/or economic interests, donors provide more regime-compatible 
democracy aid to support authoritarian regimes. Authoritarian regimes also have strategic choices on democracy aid types and can adjust the composition of democracy aid using their leverage over donors. My argument theorizes how both donors and recipient countries involve democracy aid allocation.

In Chapter 3, I examine the strategic choices of donors on democracy aid. The empirical findings from U.S. democracy aid allocation show that the U.S. provides more regime-compatible democracy aid to authoritarian regimes that are defense alliance, recipient of military assistance, and supporting the U.S. in UNGA. The U.S. is more likely to allocate favorable democracy aid to authoritarian regimes that serve U.S. security interests. It implies that donors make a strategic choice on democracy aid, depending primarily on whether authoritarian regimes are essential for donors' security and/or economic interests.

On the other hand, Chapter 4 tests whether strategic choices of authoritarian regimes can affect democracy aid allocation. I examine how authoritarian leaders' political demands affect the composition of democracy aid using U.S. democracy aid. The findings suggest that the U.S. provides more democracy aid to an authoritarian regime in a clientelistic relationship with the U.S. if the authoritarian regime has a problem with higher political instability. However, the U.S. instead reduces regime-compatible democracy aid to authoritarian regimes that are not clients states of the U.S. The empirical results indicate that recipient countries can reflect their needs for democracy aid allocation based on the relationship with donors. A recipient country has more leverage over donors depending on whether the recipient country has a clientelistic relationship or not. 


\section{Contributions to Democracy Aid Allocation}

My theoretical arguments and findings contribute to explaining the allocation patterns of democracy aid and to providing implications for democracy promotion. Firstly, my research provides a theoretical mechanism on democracy aid allocation. Despite the unique characteristics of democracy aid, the literature does shed light on democracy aid allocation mechanisms. A conventional assumption on foreign aid is that foreign aid is a normal good to recipient countries. Recipient countries are always willing to accept foreign aid if donors want to provide it. However, democracy aid can be an opportunity and a threat to authoritarian regimes. Democracy aid, in fact, can be both a normal and an inferior good to authoritarian regimes. Therefore, authoritarian regimes are not always willing to accept democracy aid. My theoretical arguments provide an explanation when recipients have an ambivalent attitude toward democracy aid.

This argument is particularly relevant in that many recipient governments deny accepting foreign aid from Western donors because of their concerns that foreign aid can disrupt domestic politics. Recently, many authoritarian regimes denied receiving foreign (Carothers 2015). For instance, in 2004, Uzbekistan adopted a new law to restrict foreign support to political parties. This policy outlaws financial and material aid from foreign donors, so that political parties in Uzbekistan cannot have external support for technical matters, training, or conferences. Some countries rejected foreign aid to demonstrate their political capability (Carnegie \& Dolan 2020). Although foreign aid is also considered an external intervention to recipient countries — even if aid provides benefits-existing literature often does not account for recipient preferences on foreign aid. 
Second, the theoretical arguments provide a simple explanation of the interactive process of democracy aid allocation mechanisms. Donors and recipient countries have different interests and preferences on democracy aid, making a strategic decision on allocation. From the donors' perspective, they provide democracy aid for normative commitment to democracy promotion and security and economic interests. To donors, recipient countries have different level of importance to them, and donors want to maintain a good relationship with recipient governments and support them to stay in power as long as they can, regardless of recipients' regime types. Additionally, authoritarian leaders in recipient countries accept democracy aid for economic and political benefits. In particular, authoritarian regimes operate under different political conditions, generating divergent perspectives on democracy aid. For instance, authoritarian regimes hold different attitudes toward democracy aid for elections, regardless of whether they are multiparty regimes or not. In this regard, my theoretical arguments incorporate multi-dimensional characteristics of the democracy aid allocation process.

In this regard, the understanding and evaluation of aid agents of donors on the political constraints of recipient countries is essential to democracy aid allocation. Depending on the domestic conditions of authoritarian regimes, some types of democracy aid are not effective in promoting democracy. Instead, it can serve to help the political stability of authoritarian regimes. It is also important because "aggressive" democracy aid can make authoritarian regimes reject democracy aid.

Third, my arguments shed light on the quality of democracy aid. Most of the previous studies on foreign aid focus on the volume of democracy aid flow (e.g., Knack 
2004, Dunning 2004, Djankov, Montalvo \& Reynal-Querol 2008, Bermeo 2011). However, democracy aid consists of diverse types that target various democratic institutions, practices, and norms in recipient countries. Each type of democracy aid has a different political impact on authoritarian regimes. Furthermore, the impact of different types of democracy aid can be more divergent in authoritarian regimes by its institutional traits. Therefore, the volume of democracy aid is important for evaluating the effectiveness of democracy aid, but it is also important to consider what types of democracy aid are delivered to which types of authoritarian regimes.

\section{For the Further Research}

Further research on democracy aid can be taken in a number of directions. There are still some arbitrary decisions on the regime compatibility of each type of democracy aid. In my research, I apply HTW authoritarian regimes typology, and they classify authoritarian regimes into five types: multiparty, one-party, no-party, military, and monarchy. Although their typology differentiates between each type of authoritarian regime based on institutional traits, authoritarian regimes are not entirely defined by their criteria. As HTW included "hybrid regimes," which is an alternative typology on regime types to identify overlapping characteristics between main types, the variance of authoritarian regimes is large. Other regime typologies also have equivocal properties between their regime types (e.g., Geddes, Wright \& Frantz 2014, Wahman, Teorell \& Hadenius 2013, Cheibub, Gandhi \& Vreeland 2010, Magaloni, Chu \& Min 2013). Because of the ambiguity involved with regime typologies, some types of democracy aid to authoritarian regimes are ambiguous to define between regime-compatible and regime-incompatible democ- 
racy aid. Therefore, we need to consider how to classify the authoritarian regimes from the democracy aid donors' perspective.

In a similar vein, we need to think about democratic aid typology. Because of the limitations of aid data, I classified democracy aid into eight subtypes based on the OECD DAC CRS classification. However, there are other ways to define democracy aid types. The democracy aid typology also may have different categories, depending on the definition of democracy and democratization. One challenging part of my typology is that it defines more than one-third of democracy aid for governance type. Although the governance type has the same characteristics in that they target institutional building of recipient government to improve public services provision, some sub-categories—such as aid for anti-corruption institutions or regional governments-can be considered a different type. Further research thus focus on developing and refining definitions and typologies of democracy aid.

Finally, a key empirical challenge involves operationalizing key concepts such as donor interests, donor-recipient relations, and recipient needs. I use various proxies to capture donors' interests consistent with prior research, but they suffer from theoretical limitations. Specifically, it is hard to capture the relationship reflecting donors' changing interests in recipient countries because most formal relationships are static once established. Moreover, countries do not reveal their interests. I operationalize the donorrecipient relationship based on the amount of military aid received. However, future researchers need to consider alternative measurements, including instrumental variables. This is one reason why I focused on only U.S democracy aid. As such, future research 
should consider how to measure the changing interests of different donors in recipient countries. 


\section{Appendix A}

\section{Summary Statistics of Variables}

Table A.1: Chapter 3. Summary Statistics of Variables

\begin{tabular}{|c|c|c|c|c|c|}
\hline Statistic & $\mathrm{N}$ & Mean & St. Dev. & Min & $\operatorname{Max}$ \\
\hline RC Aid (\%) & 1,153 & 82.580 & 28.975 & 0.100 & 100.100 \\
\hline RC Aid Total & 1,153 & $25,883,718.000$ & $127,656,416.000$ & 0 & $2,184,907,868$ \\
\hline Oil Import (\%) & 1,153 & 0.581 & 2.299 & 0 & 18 \\
\hline Total Trade & 1,150 & $8,527.163$ & $47,235.450$ & 0.000 & $641,979.500$ \\
\hline Defense Alliance & 1,153 & 0.090 & 0.287 & 0 & 1 \\
\hline UNGA Voting Similarity & 995 & 0.270 & 0.124 & 0.000 & 1.000 \\
\hline US Military Aid & 1,153 & $126,635,267.000$ & $759,098,047.000$ & 0 & $11,534,628,649$ \\
\hline Number of Terror & 1,153 & 37.682 & 175.815 & 0 & 2,852 \\
\hline Population & 1,152 & $43,940,540.000$ & $146,601,811.000$ & $74,674.000$ & $1,357,380,000.000$ \\
\hline GDP per capita & 1,114 & $2,541.514$ & $3,516.067$ & 164.337 & $60,861.270$ \\
\hline Polity score & 1,100 & 4.556 & 2.592 & 0.000 & 9.500 \\
\hline Polity score (FD) & 1,097 & 0.127 & 1.839 & -15.000 & 13.000 \\
\hline Disaster Death & 1,153 & 534.803 & $8,442.576$ & 1 & 222,570 \\
\hline ln.Total Trade & 1,153 & 14.253 & 3.970 & 0.000 & 21.505 \\
\hline ln.US Military Aid & 1,150 & 6.030 & 2.334 & 0.000 & 13.372 \\
\hline Number of Terror & 1,153 & 12.028 & 6.287 & 0 & 23 \\
\hline ln.Population & 1,152 & 16.417 & 1.432 & 11.221 & 21.029 \\
\hline ln.GDP per capita & 1,114 & 7.271 & 1.044 & 5.108 & 11.016 \\
\hline ln.Disaster Death & 1,153 & 1.417 & 1.733 & 0.693 & 12.313 \\
\hline
\end{tabular}




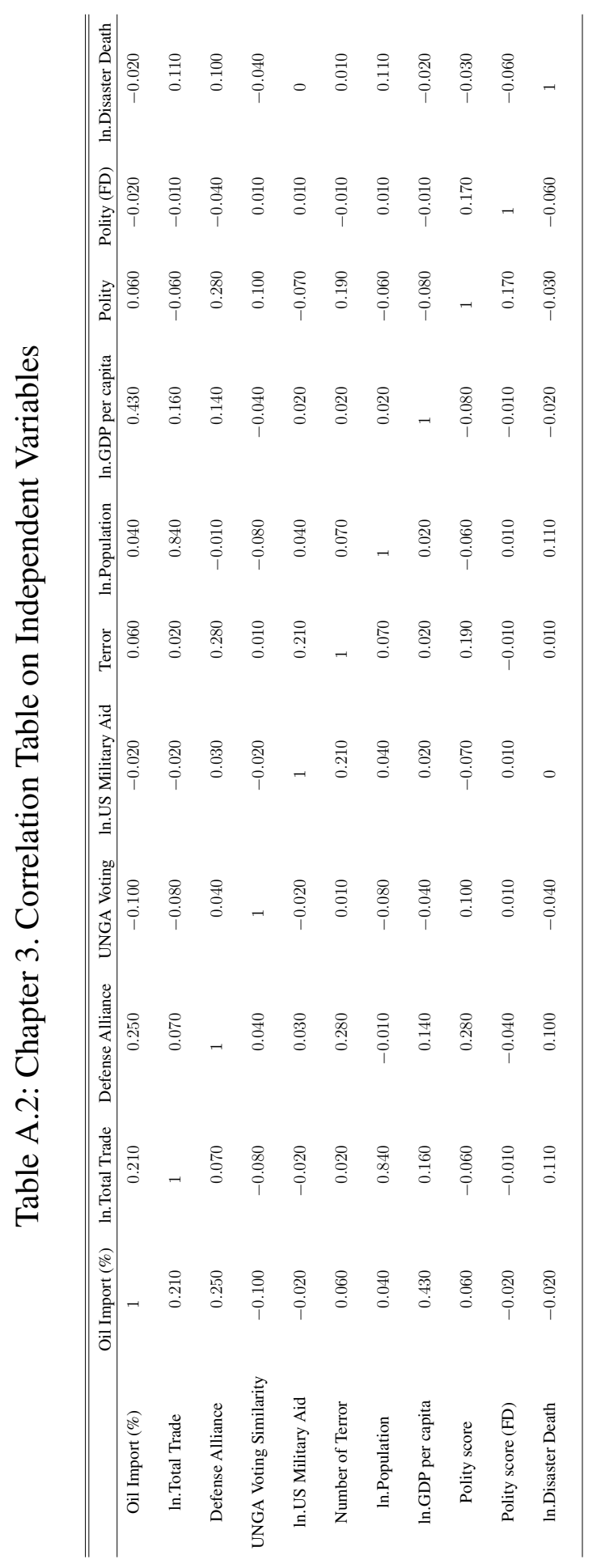




\section{Appendix B}

\section{Classification of Democracy Aid Subtypes}

Table B.1: Democracy Aid Sub-types by OECD DAC Classification

\begin{tabular}{c|l|l}
\hline \hline \multicolumn{2}{l|}{ OECD DAC Code } & \multirow{1}{|c}{ Democracy Aid Sub-types } \\
\hline Code & \multicolumn{1}{|c}{ Description } & \\
\hline 15110 & $\begin{array}{l}\text { Public sector policy and administrative man- } \\
\text { agement }\end{array}$ & \\
15111 & $\begin{array}{l}\text { Public finance management (PFM) } \\
\text { Decentralization and support to sub-national } \\
\text { government }\end{array}$ & \\
15112 & $\begin{array}{l}\text { Anti-corruption organizations and institu- } \\
\text { tions }\end{array}$ & \\
15114 & $\begin{array}{l}\text { Domestic revenue mobilization } \\
15125\end{array}$ & Public Procurement \\
\hline 15130 & Legal and judicial development & \\
\hline 15150 & Democratic participation and civil society & Civil Society \\
\hline 15151 & Elections & Election \\
\hline 15152 & Legislatures and political parties & Legislature and Political Party \\
\hline 15153 & Media and free flow of information & Media \\
\hline 15160 & Human rights & Human Rights \\
\hline 15170 & Women's rights organizations and move- & Women's Right \\
15180 & ments, and government institutions & \\
\hline
\end{tabular}




\section{Appendix C}

\section{Additional Models for Ch.3}

3. I estimate the same models in Chapter 3 using the random effect models. The results are similar to Prais-Winsten estimations in Chapter 3. 
Table C.1: Random Effect Models

\begin{tabular}{|c|c|c|c|c|c|c|}
\hline & \multicolumn{6}{|c|}{ Dependent variable: } \\
\hline & \multicolumn{6}{|c|}{ Total of Regime Compatible Democracy Aid of the US } \\
\hline & $(1)$ & (2) & (3) & (4) & (5) & $(6)$ \\
\hline Lagged $\mathrm{DV}_{t-1}$ & $\begin{array}{l}0.502^{* * *} \\
(0.026)\end{array}$ & $\begin{array}{l}0.471^{* * *} \\
(0.030)\end{array}$ & $\begin{array}{l}0.449^{* * *} \\
(0.030)\end{array}$ & $\begin{array}{l}0.419^{* * *} \\
(0.030)\end{array}$ & $\begin{array}{l}0.449^{* * *} \\
(0.030)\end{array}$ & $\begin{array}{l}0.417^{* * *} \\
(0.030)\end{array}$ \\
\hline Oil Import (percent) & $\begin{array}{c}-0.172^{* * *} \\
(0.047)\end{array}$ & $\begin{array}{c}-0.179^{* * *} \\
(0.049)\end{array}$ & $\begin{array}{c}-0.166^{* * *} \\
(0.049)\end{array}$ & $\begin{array}{c}-0.179^{* * *} \\
(0.051)\end{array}$ & $\begin{array}{c}-0.165^{* * *} \\
(0.049)\end{array}$ & $\begin{array}{c}-0.179^{* * *} \\
(0.051)\end{array}$ \\
\hline ln.Total Trade & $\begin{array}{c}0.081 \\
(0.085)\end{array}$ & $\begin{array}{c}0.145 \\
(0.095)\end{array}$ & $\begin{array}{c}0.097 \\
(0.095)\end{array}$ & $\begin{array}{c}0.028 \\
(0.098)\end{array}$ & $\begin{array}{c}0.097 \\
(0.095)\end{array}$ & $\begin{array}{c}0.028 \\
(0.098)\end{array}$ \\
\hline Defense Alliance (Dummy) & $\begin{array}{l}1.052^{* * *} \\
(0.357)\end{array}$ & $\begin{array}{l}0.991^{* *} \\
(0.388)\end{array}$ & $\begin{array}{c}0.951^{* *} \\
(0.385)\end{array}$ & $\begin{array}{c}0.617 \\
(0.408)\end{array}$ & $\begin{array}{l}0.928^{* *} \\
(0.397)\end{array}$ & $\begin{array}{c}0.607 \\
(0.416)\end{array}$ \\
\hline UNGA Voting Similarity & & $\begin{array}{l}1.831^{* *} \\
(0.891)\end{array}$ & $\begin{array}{l}1.768^{* *} \\
(0.884)\end{array}$ & $\begin{array}{c}1.273 \\
(0.888)\end{array}$ & $\begin{array}{c}1.766^{* *} \\
(0.885)\end{array}$ & $\begin{array}{c}1.262 \\
(0.889)\end{array}$ \\
\hline ln.US Military Aid & & & $\begin{array}{l}0.068^{* * *} \\
(0.018)\end{array}$ & $\begin{array}{l}0.057^{* * *} \\
(0.018)\end{array}$ & $\begin{array}{l}0.068^{* * *} \\
(0.018)\end{array}$ & $\begin{array}{l}0.057^{* * *} \\
(0.018)\end{array}$ \\
\hline Number of Terror & & & & & $\begin{array}{c}0.0003 \\
(0.001)\end{array}$ & $\begin{array}{r}0.0002 \\
(0.001)\end{array}$ \\
\hline ln.Population & $\begin{array}{l}0.387^{* * *} \\
(0.118)\end{array}$ & $\begin{array}{l}0.341^{* * *} \\
(0.130)\end{array}$ & $\begin{array}{l}0.346^{* * *} \\
(0.129)\end{array}$ & $\begin{array}{l}0.435^{* * *} \\
(0.133)\end{array}$ & $\begin{array}{l}0.343^{* * *} \\
(0.130)\end{array}$ & $\begin{array}{l}0.435^{* * *} \\
(0.135)\end{array}$ \\
\hline ln.GDP per capita & $\begin{array}{c}0.071 \\
(0.146)\end{array}$ & $\begin{array}{c}-0.007 \\
(0.161)\end{array}$ & $\begin{array}{c}0.006 \\
(0.160)\end{array}$ & $\begin{array}{c}0.194 \\
(0.171)\end{array}$ & $\begin{array}{c}0.005 \\
(0.160)\end{array}$ & $\begin{array}{c}0.193 \\
(0.172)\end{array}$ \\
\hline Polity score (FD) & $\begin{array}{c}0.062 \\
(0.052)\end{array}$ & $\begin{array}{c}0.024 \\
(0.057)\end{array}$ & $\begin{array}{c}0.029 \\
(0.056)\end{array}$ & & $\begin{array}{c}0.029 \\
(0.056)\end{array}$ & \\
\hline Polity score & & & & $\begin{array}{l}0.184^{* * *} \\
(0.046)\end{array}$ & & $\begin{array}{l}0.184^{* * *} \\
(0.046)\end{array}$ \\
\hline ln.Disaster Death & $\begin{array}{c}-0.073 \\
(0.055)\end{array}$ & $\begin{array}{c}-0.060 \\
(0.059)\end{array}$ & $\begin{array}{c}-0.038 \\
(0.059)\end{array}$ & $\begin{array}{c}-0.040 \\
(0.059)\end{array}$ & $\begin{array}{c}-0.039 \\
(0.059)\end{array}$ & $\begin{array}{c}-0.040 \\
(0.059)\end{array}$ \\
\hline Constant & $\begin{array}{c}-0.203 \\
(2.295)\end{array}$ & $\begin{array}{c}0.675 \\
(2.517)\end{array}$ & $\begin{array}{c}0.285 \\
(2.500)\end{array}$ & $\begin{array}{c}-2.232 \\
(2.638)\end{array}$ & $\begin{array}{c}0.361 \\
(2.522)\end{array}$ & $\begin{array}{c}-2.196 \\
(2.671)\end{array}$ \\
\hline Observations & 1,055 & 914 & 914 & 916 & 914 & 916 \\
\hline $\mathrm{R}^{2}$ & 0.333 & 0.308 & 0.319 & 0.292 & 0.319 & 0.289 \\
\hline Adjusted $\mathrm{R}^{2}$ & 0.328 & 0.301 & 0.312 & 0.285 & 0.311 & 0.281 \\
\hline
\end{tabular}


Table C.2: Random Effect Models

\begin{tabular}{|c|c|c|c|c|c|c|}
\hline & \multicolumn{6}{|c|}{ Dependent variable: } \\
\hline & \multicolumn{6}{|c|}{ Percentage of Regime Compatible Democracy Aid of the US } \\
\hline & $(1)$ & $(2)$ & (3) & (4) & $(5)$ & (6) \\
\hline Lagged $\mathrm{DV}_{t-1}$ & $\begin{array}{l}0.540^{* * *} \\
(0.026)\end{array}$ & $\begin{array}{l}0.513^{* * *} \\
(0.029)\end{array}$ & $\begin{array}{l}0.503^{* * *} \\
(0.030)\end{array}$ & $\begin{array}{l}0.501^{* * *} \\
(0.029)\end{array}$ & $\begin{array}{c}0.502^{* * *} \\
(0.030)\end{array}$ & $\begin{array}{l}0.500^{* * *} \\
(0.030)\end{array}$ \\
\hline Oil Import (percent) & $\begin{array}{c}-0.341 \\
(0.328)\end{array}$ & $\begin{array}{c}-0.392 \\
(0.347)\end{array}$ & $\begin{array}{c}-0.316 \\
(0.348)\end{array}$ & $\begin{array}{c}-0.352 \\
(0.347)\end{array}$ & $\begin{array}{c}-0.337 \\
(0.349)\end{array}$ & $\begin{array}{c}-0.371 \\
(0.348)\end{array}$ \\
\hline ln.Total Trade & $\begin{array}{c}0.348 \\
(0.606)\end{array}$ & $\begin{array}{c}0.913 \\
(0.677)\end{array}$ & $\begin{array}{c}0.707 \\
(0.681)\end{array}$ & $\begin{array}{c}0.424 \\
(0.689)\end{array}$ & $\begin{array}{c}0.707 \\
(0.681)\end{array}$ & $\begin{array}{c}0.418 \\
(0.689)\end{array}$ \\
\hline Defense Alliance (Dummy) & $\begin{array}{c}4.904^{*} \\
(2.534)\end{array}$ & $\begin{array}{c}4.415 \\
(2.753)\end{array}$ & $\begin{array}{l}4.180 \\
(2.748)\end{array}$ & $\begin{array}{c}2.845 \\
(2.803)\end{array}$ & $\begin{array}{r}4.793^{*} \\
(2.838)\end{array}$ & $\begin{array}{c}3.389 \\
(2.850)\end{array}$ \\
\hline UNGA Voting Similarity & & $\begin{array}{l}17.983^{* * *} \\
(6.324)\end{array}$ & $\begin{array}{l}17.552^{* * *} \\
(6.312)\end{array}$ & $\begin{array}{l}15.671^{* *} \\
(6.328)\end{array}$ & $\begin{array}{l}17.648^{* * *} \\
(6.314)\end{array}$ & $\begin{array}{l}15.689^{* *} \\
(6.327)\end{array}$ \\
\hline ln.US Military Aid & & & $\begin{array}{c}0.285^{* *} \\
(0.127)\end{array}$ & $\begin{array}{c}0.231^{*} \\
(0.129)\end{array}$ & $\begin{array}{c}0.296^{* *} \\
(0.128)\end{array}$ & $\begin{array}{c}0.241^{*} \\
(0.129)\end{array}$ \\
\hline Number of Terror & & & & & $\begin{array}{c}-0.009 \\
(0.010)\end{array}$ & $\begin{array}{c}-0.009 \\
(0.009)\end{array}$ \\
\hline ln.Population & $\begin{array}{c}-0.064 \\
(0.845)\end{array}$ & $\begin{array}{c}-0.337 \\
(0.924)\end{array}$ & $\begin{array}{c}-0.371 \\
(0.922)\end{array}$ & $\begin{array}{c}-0.115 \\
(0.926)\end{array}$ & $\begin{array}{c}-0.272 \\
(0.929)\end{array}$ & $\begin{array}{c}0.002 \\
(0.932)\end{array}$ \\
\hline ln.GDP per capita & $\begin{array}{c}0.109 \\
(1.040)\end{array}$ & $\begin{array}{c}-0.494 \\
(1.149)\end{array}$ & $\begin{array}{c}-0.458 \\
(1.146)\end{array}$ & $\begin{array}{c}0.289 \\
(1.184)\end{array}$ & $\begin{array}{c}-0.422 \\
(1.147)\end{array}$ & $\begin{array}{c}0.364 \\
(1.186)\end{array}$ \\
\hline Polity score (FD) & $\begin{array}{c}0.048 \\
(0.372)\end{array}$ & $\begin{array}{c}-0.284 \\
(0.404)\end{array}$ & $\begin{array}{c}-0.263 \\
(0.403)\end{array}$ & & $\begin{array}{c}-0.264 \\
(0.403)\end{array}$ & \\
\hline Polity score & & & & $\begin{array}{c}0.728^{* *} \\
(0.320)\end{array}$ & & $\begin{array}{c}0.766^{* *} \\
(0.322)\end{array}$ \\
\hline ln.Disaster Death & $\begin{array}{c}0.035 \\
(0.393)\end{array}$ & $\begin{array}{c}0.027 \\
(0.422)\end{array}$ & $\begin{array}{c}0.122 \\
(0.424)\end{array}$ & $\begin{array}{c}0.107 \\
(0.422)\end{array}$ & $\begin{array}{c}0.133 \\
(0.424)\end{array}$ & $\begin{array}{c}0.114 \\
(0.422)\end{array}$ \\
\hline Constant & $\begin{array}{c}38.184^{* *} \\
(16.693)\end{array}$ & $\begin{array}{l}41.315^{* *} \\
(18.206)\end{array}$ & $\begin{array}{c}40.328^{* *} \\
(18.171)\end{array}$ & $\begin{array}{c}30.614^{*} \\
(18.597)\end{array}$ & $\begin{array}{c}38.525^{* *} \\
(18.292)\end{array}$ & $\begin{array}{c}28.169 \\
(18.742)\end{array}$ \\
\hline Observations & 1,055 & 914 & 914 & 916 & 914 & 916 \\
\hline $\mathrm{R}^{2}$ & 0.305 & 0.286 & 0.290 & 0.294 & 0.290 & 0.294 \\
\hline Adjusted $\mathrm{R}^{2}$ & 0.300 & 0.279 & 0.282 & 0.286 & 0.282 & 0.286 \\
\hline
\end{tabular}




\section{Appendix D}

\section{Additional Models for $\mathbf{C h . 4}$}

In this section, I include alternative models for Chapter 4. I test the same models in Chapter 4 with different military aid variables. First, Table D.1 and D.2 are the same models Table 4.1 and 4.2 with original continuous variables. Table D.3 and D.4 include alternative models with different military aid dummy. The military aid (dummy) variable in these models is defined with the median value of military aid. If military aid is larger than the 3rd quantile threshold, I coded 1, otherwise 0 . The results are almost similar to the original models in Chapter 4. 
Table D.1: Fixed Effect Models (CSO Repression $\times$ Military Aid)

\begin{tabular}{|c|c|c|c|c|}
\hline & \multicolumn{4}{|c|}{ Dependent variable: Regime-Compatible Democracy Aid } \\
\hline & \multicolumn{2}{|c|}{ Total } & \multicolumn{2}{|c|}{ Ratio } \\
\hline & (1) & (2) & (3) & (4) \\
\hline Lagged $\mathrm{DV}_{t-1}$ & $\begin{array}{l}0.205^{* * *} \\
(0.038)\end{array}$ & $\begin{array}{l}0.208^{* * *} \\
(0.038)\end{array}$ & $\begin{array}{l}0.298^{* * *} \\
(0.037)\end{array}$ & $\begin{array}{c}0.297^{* * *} \\
(0.037)\end{array}$ \\
\hline Oil Import (\%) & $\begin{array}{c}-0.248^{* * *} \\
(0.090)\end{array}$ & $\begin{array}{c}-0.253^{* * *} \\
(0.091)\end{array}$ & $\begin{array}{c}0.199 \\
(0.689)\end{array}$ & $\begin{array}{c}0.178 \\
(0.691)\end{array}$ \\
\hline CSO Repression & $\begin{array}{c}-2.318^{* * *} \\
(0.528)\end{array}$ & $\begin{array}{c}-3.035^{* * *} \\
(0.498)\end{array}$ & $\begin{array}{c}-11.702^{* * *} \\
(4.068)\end{array}$ & $\begin{array}{c}-13.393^{* * *} \\
(3.793)\end{array}$ \\
\hline Military Aid & $\begin{array}{c}-0.163^{* *} \\
(0.064)\end{array}$ & $\begin{array}{c}-0.156^{* *} \\
(0.064)\end{array}$ & $\begin{array}{c}-1.222^{* *} \\
(0.493)\end{array}$ & $\begin{array}{c}-1.213^{* *} \\
(0.494)\end{array}$ \\
\hline Military Aid $\times$ CSO Repression & $\begin{array}{l}0.117^{* * *} \\
(0.028)\end{array}$ & $\begin{array}{l}0.120^{* * *} \\
(0.028)\end{array}$ & $\begin{array}{l}0.784^{* * *} \\
(0.216)\end{array}$ & $\begin{array}{c}0.788^{* * *} \\
(0.217)\end{array}$ \\
\hline Governance & $\begin{array}{c}-0.206 \\
(0.650)\end{array}$ & $\begin{array}{c}0.078 \\
(0.655)\end{array}$ & $\begin{array}{c}8.404^{*} \\
(5.058)\end{array}$ & $\begin{array}{c}8.981^{*} \\
(5.053)\end{array}$ \\
\hline Polity & $\begin{array}{l}0.389^{* * *} \\
(0.099)\end{array}$ & & $\begin{array}{c}0.855 \\
(0.768)\end{array}$ & \\
\hline Polity (FD) & & $\begin{array}{c}0.092 \\
(0.062)\end{array}$ & & $\begin{array}{c}-0.055 \\
(0.473)\end{array}$ \\
\hline ln.Population & $\begin{array}{l}1.092^{* * *} \\
(0.325)\end{array}$ & $\begin{array}{l}1.039^{* * *} \\
(0.328)\end{array}$ & $\begin{array}{c}-0.351 \\
(2.511)\end{array}$ & $\begin{array}{c}-0.454 \\
(2.513)\end{array}$ \\
\hline ln.GDP per capita & $\begin{array}{c}-0.009 \\
(0.351)\end{array}$ & $\begin{array}{c}0.195 \\
(0.351)\end{array}$ & $\begin{array}{c}-8.650^{* * *} \\
(2.757)\end{array}$ & $\begin{array}{c}-8.158^{* * *} \\
(2.733)\end{array}$ \\
\hline ln.Disaster Death & $\begin{array}{c}0.037 \\
(0.070)\end{array}$ & $\begin{array}{c}0.030 \\
(0.070)\end{array}$ & $\begin{array}{c}0.199 \\
(0.539)\end{array}$ & $\begin{array}{c}0.162 \\
(0.540)\end{array}$ \\
\hline Civil War & $\begin{array}{c}-0.978 \\
(0.793)\end{array}$ & $\begin{array}{c}-0.839 \\
(0.801)\end{array}$ & $\begin{array}{c}-2.861 \\
(6.137)\end{array}$ & $\begin{array}{c}-2.488 \\
(6.142)\end{array}$ \\
\hline Observations & 772 & 771 & 772 & 771 \\
\hline $\mathrm{R}^{2}$ & 0.213 & 0.197 & 0.169 & 0.167 \\
\hline adjusted $\mathrm{R}^{2}$ & 0.097 & 0.079 & 0.046 & 0.044 \\
\hline
\end{tabular}


Table D.2: Fixed Effect Models (Political Terror $\times$ Military Aid)

\begin{tabular}{|c|c|c|c|c|}
\hline & \multicolumn{4}{|c|}{ Dependent variable: Regime-Compatible Democracy Aid } \\
\hline & \multicolumn{2}{|c|}{ Total } & \multicolumn{2}{|c|}{ Ratio } \\
\hline & (1) & (2) & (3) & (4) \\
\hline Lagged $\mathrm{DV}_{t-1}$ & $\begin{array}{l}0.199^{* * *} \\
(0.038)\end{array}$ & $\begin{array}{l}0.213^{* * *} \\
(0.039)\end{array}$ & $\begin{array}{l}0.296^{* * *} \\
(0.038)\end{array}$ & $\begin{array}{c}0.294^{* * *} \\
(0.038)\end{array}$ \\
\hline Oil Import (\%) & $\begin{array}{c}-0.289^{* * *} \\
(0.091)\end{array}$ & $\begin{array}{c}-0.308^{* * *} \\
(0.093)\end{array}$ & $\begin{array}{c}0.026 \\
(0.695)\end{array}$ & $\begin{array}{c}-0.036 \\
(0.696)\end{array}$ \\
\hline Political Terror & $\begin{array}{c}-1.466^{* * *} \\
(0.382)\end{array}$ & $\begin{array}{c}-1.513^{* * *} \\
(0.391)\end{array}$ & $\begin{array}{c}-8.071^{* * *} \\
(2.976)\end{array}$ & $\begin{array}{c}-8.224^{* * *} \\
(2.982)\end{array}$ \\
\hline Military Aid & $\begin{array}{c}-0.331^{* * *} \\
(0.094)\end{array}$ & $\begin{array}{c}-0.320^{* * *} \\
(0.096)\end{array}$ & $\begin{array}{c}-1.602^{* *} \\
(0.733)\end{array}$ & $\begin{array}{c}-1.601^{* *} \\
(0.735)\end{array}$ \\
\hline Military Aid $\times$ Political Terror & $\begin{array}{l}0.119^{* * *} \\
(0.026)\end{array}$ & $\begin{array}{l}0.123^{* * *} \\
(0.026)\end{array}$ & $\begin{array}{l}0.570^{* * *} \\
(0.200)\end{array}$ & $\begin{array}{c}0.583^{* * *} \\
(0.200)\end{array}$ \\
\hline Governance & $\begin{array}{c}0.390 \\
(0.669)\end{array}$ & $\begin{array}{c}1.188^{*} \\
(0.670)\end{array}$ & $\begin{array}{l}10.232^{*} \\
(5.221)\end{array}$ & $\begin{array}{l}11.880^{* *} \\
(5.121)\end{array}$ \\
\hline Polity & $\begin{array}{l}0.482^{* * *} \\
(0.085)\end{array}$ & & $\begin{array}{c}0.964 \\
(0.660)\end{array}$ & \\
\hline Polity score (FD) & & $\begin{array}{c}0.112^{*} \\
(0.062)\end{array}$ & & $\begin{array}{c}-0.046 \\
(0.473)\end{array}$ \\
\hline ln.Population & $\begin{array}{l}1.050^{* * *} \\
(0.325)\end{array}$ & $\begin{array}{l}1.038^{* * *} \\
(0.332)\end{array}$ & $\begin{array}{c}-0.795 \\
(2.518)\end{array}$ & $\begin{array}{c}-0.785 \\
(2.524)\end{array}$ \\
\hline ln.GDP per capita & $\begin{array}{c}-0.291 \\
(0.335)\end{array}$ & $\begin{array}{c}-0.269 \\
(0.343)\end{array}$ & $\begin{array}{c}-9.584^{* * *} \\
(2.647)\end{array}$ & $\begin{array}{c}-9.536^{* * *} \\
(2.655)\end{array}$ \\
\hline ln.Disaster Death & $\begin{array}{c}0.026 \\
(0.070)\end{array}$ & $\begin{array}{c}0.012 \\
(0.071)\end{array}$ & $\begin{array}{c}0.135 \\
(0.541)\end{array}$ & $\begin{array}{c}0.084 \\
(0.542)\end{array}$ \\
\hline Civil War & $\begin{array}{c}-1.086 \\
(0.787)\end{array}$ & $\begin{array}{c}-1.145 \\
(0.805)\end{array}$ & $\begin{array}{c}-2.546 \\
(6.115)\end{array}$ & $\begin{array}{c}-2.616 \\
(6.133)\end{array}$ \\
\hline Observations & 772 & 771 & 772 & 771 \\
\hline $\mathrm{R}^{2}$ & 0.213 & 0.179 & 0.163 & 0.160 \\
\hline adjusted $R^{2}$ & 0.096 & 0.058 & 0.039 & 0.036 \\
\hline
\end{tabular}


Table D.3: Fixed Effect Models (CSO Repression $\times$ Military Aid (Dummy)

\begin{tabular}{|c|c|c|c|c|}
\hline & \multicolumn{4}{|c|}{ Dependent variable: Regime-Compatible Democracy Aid } \\
\hline & \multicolumn{2}{|c|}{ Total } & \multicolumn{2}{|c|}{ Ratio } \\
\hline & $(1)$ & $(2)$ & (3) & $(4)$ \\
\hline Lagged $\mathrm{DV}_{t-1}$ & $\begin{array}{c}0.033 \\
(0.036)\end{array}$ & $\begin{array}{c}0.040 \\
(0.036)\end{array}$ & $\begin{array}{l}0.177^{* * *} \\
(0.037)\end{array}$ & $\begin{array}{l}0.177^{* * *} \\
(0.037)\end{array}$ \\
\hline Oil Import (\%) & $\begin{array}{c}-0.360^{* * *} \\
(0.093)\end{array}$ & $\begin{array}{c}-0.368^{* * *} \\
(0.094)\end{array}$ & $\begin{array}{c}0.069 \\
(0.717)\end{array}$ & $\begin{array}{c}0.044 \\
(0.718)\end{array}$ \\
\hline CSO Repression & $\begin{array}{c}-1.475^{* * *} \\
(0.411)\end{array}$ & $\begin{array}{c}-2.244^{* * *} \\
(0.358)\end{array}$ & $\begin{array}{r}-5.757^{*} \\
(3.173)\end{array}$ & $\begin{array}{c}-7.117^{* * *} \\
(2.734)\end{array}$ \\
\hline Military Aid (Dummy) & $\begin{array}{c}-1.573^{* *} \\
(0.797)\end{array}$ & $\begin{array}{c}-1.732^{* *} \\
(0.807)\end{array}$ & $\begin{array}{c}-13.956^{* *} \\
(6.191)\end{array}$ & $\begin{array}{c}-14.245^{* *} \\
(6.207)\end{array}$ \\
\hline Military Aid $\times$ CSO Repression & $\begin{array}{l}1.229^{* * *} \\
(0.402)\end{array}$ & $\begin{array}{l}1.374^{* * *} \\
(0.405)\end{array}$ & $\begin{array}{l}9.455^{* * *} \\
(3.117)\end{array}$ & $\begin{array}{l}9.661^{* * *} \\
(3.112)\end{array}$ \\
\hline Governance & $\begin{array}{c}0.642 \\
(0.664)\end{array}$ & $\begin{array}{c}0.957 \\
(0.669)\end{array}$ & $\begin{array}{l}14.585^{* * *} \\
(5.159)\end{array}$ & $\begin{array}{l}15.042^{* * *} \\
(5.146)\end{array}$ \\
\hline Polity & $\begin{array}{c}0.393^{* * *} \\
(0.103)\end{array}$ & & $\begin{array}{c}0.649 \\
(0.801)\end{array}$ & \\
\hline Polity (FD) & & $\begin{array}{c}0.073 \\
(0.064)\end{array}$ & & $\begin{array}{c}-0.139 \\
(0.491)\end{array}$ \\
\hline ln.Population & $\begin{array}{l}1.333^{* * *} \\
(0.331)\end{array}$ & $\begin{array}{l}1.304^{* * *} \\
(0.335)\end{array}$ & $\begin{array}{c}-0.254 \\
(2.562)\end{array}$ & $\begin{array}{c}-0.300 \\
(2.564)\end{array}$ \\
\hline ln.GDP per capita & $\begin{array}{c}0.007 \\
(0.366)\end{array}$ & $\begin{array}{c}0.233 \\
(0.365)\end{array}$ & $\begin{array}{c}-10.512^{* * *} \\
(2.863)\end{array}$ & $\begin{array}{c}-10.101^{* * *} \\
(2.828)\end{array}$ \\
\hline ln.Disaster Death & $\begin{array}{c}0.030 \\
(0.072)\end{array}$ & $\begin{array}{c}0.021 \\
(0.073)\end{array}$ & $\begin{array}{c}0.103 \\
(0.562)\end{array}$ & $\begin{array}{c}0.069 \\
(0.563)\end{array}$ \\
\hline Civil War & $\begin{array}{c}-0.816 \\
(0.825)\end{array}$ & $\begin{array}{c}-0.687 \\
(0.833)\end{array}$ & $\begin{array}{c}-2.458 \\
(6.394)\end{array}$ & $\begin{array}{c}-2.170 \\
(6.397)\end{array}$ \\
\hline Observations & 771 & 770 & 771 & 770 \\
\hline $\mathrm{R}^{2}$ & 0.151 & 0.134 & 0.101 & 0.100 \\
\hline adjusted $\mathrm{R}^{2}$ & 0.026 & 0.006 & -0.032 & -0.033 \\
\hline
\end{tabular}


Table D.4: Fixed Effect Models (Political Terror $\times$ Military Aid (Dummy)

\begin{tabular}{|c|c|c|c|c|}
\hline & \multicolumn{4}{|c|}{ Dependent variable: Regime-Compatible Democracy Aid } \\
\hline & \multicolumn{2}{|c|}{ Total } & \multicolumn{2}{|c|}{ Ratio } \\
\hline & $(1)$ & $(2)$ & (3) & (4) \\
\hline Lagged $\mathrm{DV}_{t-1}$ & $\begin{array}{c}0.025 \\
(0.036)\end{array}$ & $\begin{array}{c}0.043 \\
(0.037)\end{array}$ & & \\
\hline Lagged $\mathrm{DV}_{t-1}$ & & & $\begin{array}{l}0.168^{* * *} \\
(0.037)\end{array}$ & $\begin{array}{l}0.167^{* * *} \\
(0.038)\end{array}$ \\
\hline Oil Import (\%) & $\begin{array}{c}-0.361^{* * *} \\
(0.094)\end{array}$ & $\begin{array}{c}-0.391^{* * *} \\
(0.096)\end{array}$ & $\begin{array}{c}0.131 \\
(0.717)\end{array}$ & $\begin{array}{c}0.051 \\
(0.717)\end{array}$ \\
\hline Political Terror & $\begin{array}{c}-0.214 \\
(0.226)\end{array}$ & $\begin{array}{c}-0.234 \\
(0.232)\end{array}$ & $\begin{array}{c}-2.417 \\
(1.742)\end{array}$ & $\begin{array}{c}-2.458 \\
(1.746)\end{array}$ \\
\hline Military Aid (Dummy) & $\begin{array}{c}-3.644^{* * *} \\
(1.286)\end{array}$ & $\begin{array}{c}-3.845^{* * *} \\
(1.326)\end{array}$ & $\begin{array}{c}-26.952^{* * *} \\
(9.931)\end{array}$ & $\begin{array}{c}-27.410^{* * *} \\
(9.988)\end{array}$ \\
\hline Governance & $\begin{array}{c}1.198^{*} \\
(0.689)\end{array}$ & $\begin{array}{l}2.256^{* * *} \\
(0.688)\end{array}$ & $\begin{array}{l}16.077^{* * *} \\
(5.330)\end{array}$ & $\begin{array}{l}18.104^{* * *} \\
(5.186)\end{array}$ \\
\hline Polity & $\begin{array}{l}0.546^{* * *} \\
(0.088)\end{array}$ & & $\begin{array}{c}1.017 \\
(0.679)\end{array}$ & \\
\hline Polity (FD) & & $\begin{array}{c}0.108^{*} \\
(0.065)\end{array}$ & & $\begin{array}{c}-0.051 \\
(0.490)\end{array}$ \\
\hline ln.Population & $\begin{array}{l}1.205^{* * *} \\
(0.334)\end{array}$ & $\begin{array}{l}1.233^{* * *} \\
(0.343)\end{array}$ & $\begin{array}{r}-1.513 \\
(2.577)\end{array}$ & $\begin{array}{c}-1.432 \\
(2.583)\end{array}$ \\
\hline ln.GDP per capita & $\begin{array}{c}-0.376 \\
(0.350)\end{array}$ & $\begin{array}{c}-0.349 \\
(0.359)\end{array}$ & $\begin{array}{c}-11.935^{* * *} \\
(2.729)\end{array}$ & $\begin{aligned}-11.883^{* * *} & (2.736)\end{aligned}$ \\
\hline ln.Disaster Death & $\begin{array}{c}0.032 \\
(0.073)\end{array}$ & $\begin{array}{c}0.013 \\
(0.075)\end{array}$ & $\begin{array}{c}0.111 \\
(0.561)\end{array}$ & $\begin{array}{c}0.056 \\
(0.563)\end{array}$ \\
\hline Civil War & $\begin{array}{c}-0.949 \\
(0.820)\end{array}$ & $\begin{array}{c}-1.016 \\
(0.842)\end{array}$ & $\begin{array}{c}-1.894 \\
(6.340)\end{array}$ & $\begin{array}{c}-1.952 \\
(6.359)\end{array}$ \\
\hline Military Aid imes Political Terror & $\begin{array}{l}1.301^{* * *} \\
(0.373)\end{array}$ & $\begin{array}{l}1.434^{* * *} \\
(0.384)\end{array}$ & $\begin{array}{l}9.008^{* * *} \\
(2.873)\end{array}$ & $\begin{array}{l}9.259^{* * *} \\
(2.883)\end{array}$ \\
\hline Observations & 771 & 770 & 771 & 770 \\
\hline $\mathrm{R}^{2}$ & 0.146 & 0.101 & 0.102 & 0.099 \\
\hline adjusted $\mathrm{R}^{2}$ & 0.020 & -0.032 & -0.031 & -0.035 \\
\hline
\end{tabular}




\section{Bibliography}

Acemoglu, Daron \& James A Robinson. 2001. "A Theory of Political Transitions.” American Economic Review 91(4):938-963.

Acht, Martin, Toman Omar Mahmoud \& Rainer Thiele. 2015. “Corrupt Governments Do Not Receive More State-to-State Aid: Governance and the Delivery of Foreign Aid through Non-State Actors." Journal of Development Economics 114:20-33.

Ahmed, Faisal Z. 2012. "The Perils of Unearned Foreign Income: Aid, Remittances, and Government Survival.” American Political Science Review 106(1):146-165.

Alesina, Alberto \& David Dollar. 2000. "Who Gives Foreign Aid to Whom and Why?" Journal of Economic Growth 5(1):33-63.

Apter, David E. 1965. Politics of Modernization. Chicago: The University of Chicago Press.

Azam, Jean-Paul \& Véronique Thelen. 2009. "Foreign Aid Versus Military Intervention in the War on Terror." Journal of Conflict Resolution 54(2):237-261.

Baldwin, Kate \& Matthew S Winters. 2020. "How Do Different Forms of Foreign Aid Affect Government Legitimacy? Evidence from an Informational Experiment in Uganda." Studies in comparative international development 55(2):160-183.

Bandyopadhyay, Subhayu, Todd Sandler \& Javed Younas. 2011. "Foreign Aid as Counterterrorism Policy." Oxford Economic Papers 63(3):423-447.

Bank, André, Thomas Richter \& Anna Sunik. 2013. "Long-Term Monarchical Survival in the Middle East: A Configurational Comparison, 1945-2012." Democratization 22(1):179-200.

Bapat, Navin A. 2011a. "Terrorism, Democratization, and Us Foreign Policy." Public Choice 149(3/4):315-335.

Bapat, Navin A. 2011b. "Transnational Terrorism, US Military Aid, and the Incentive to Misrepresent." Journal of Peace Research 48(3):303-318.

Barbieri, Katherine \& Omar M. G. Keshk. 2016. Correlates of War Project Trade Data Set Codebook. Version 4.0. 
Barthel, Fabian, Eric Neumayer, Peter Nunnenkamp \& Pablo Selaya. 2014. "Competition for Export Markets and the Allocation of Foreign Aid: The Role of Spatial Dependence among Donor Countries." World Development 64:350-365.

Beaulieu, Emily \& Susan D Hyde. 2008. "In the Shadow of Democracy Promotion: Strategic Manipulation, International Observers, and Election Boycotts." Comparative Political Studies 42(3):392-415.

Bermeo, Sarah Blodgett. 2011. "Foreign Aid and Regime Change: A Role for Donor Intent." World Development 39(11):2021-2031.

Bermeo, Sarah Blodgett. 2017. "Aid Allocation and Targeted Development in an Increasingly Connected World." International organization 71(4):735-766.

Blair, Robert A \& Philip Roessler. 2018. "The Effects of Chinese Aid on State Legitimacy in Africa: Cross-National and Sub-National Evidence from Surveys, Survey Experiments, and Behavioral Games." AidData Working Paper 59.

Boix, Carles. 2011. "Democracy, Development, and the International System." American Political Science Review 105(4):809-828.

Boutton, Andrew \& David B Carter. 2014. "Fair-Weather Allies? Terrorism and the Allocation of US Foreign Aid.” Journal of Conflict Resolution 58(7):1144-1173.

Bräutigam, Deborah. 2009. The Dragon's Gift: The Real Story of China in Africa. Oxford University Press.

Brownlee, Jason. 2007. Authoritarianism in an Age of Democratization. Cambridge: Combrigde University Press.

Brownlee, Jason. 2009. "Portents of Pluralism: How Hybrid Regimes Affect Democratic Transitions." American Journal of Political Science 53(3):515-532.

Bueno de Mesquita, Bruce \& Alastair Smith. 2009. "A Political Economy of Aid." International organization 63(2):309-340.

Bueno de Mesquita, Bruce, Alastair Smith, Randolph M Siverson \& James D Morrow. 2003. The Logic of Political Survival. MIT Press.

Bueno de Mesquita, Bruce, James D Morrow, Randolph M Siverson \& Alastair Smith. 1999. "Policy Failure and Political Survival The Contribution of Political Institutions." Journal of Conflict Resolution 43(2):147-161.

Bueno de Mesquita, Bruce, James D Morrow, Randolph M Siverson \& Alastair Smith. 2014. "An Institutional Explanation of the Democratic Peace." American Political Science Review 93(04):791-807.

Bunce, Valerie J \& Sharon L Wolchik. 2010. "Defeating Dictators: Electoral Change and Stability in Competitive Authoritarian Regimes.” World Politics 62(01):43-86. 
Bush, Sarah Sunn. 2015. The Taming of Democracy Assistance. Cambridge: Cambridge University Press.

Carnegie, Allison \& Lindsay R. Dolan. 2020. "The Effects of Rejecting Aid on Recipients' Reputations: Evidence from Natural Disaster Responses." The Review of International Organizations pp. 1-25.

Carothers, Thomas. 2000. Aiding Democracy Abroad: The Learning Curve. Washington, D.C.: Carnegie Endowment.

Carothers, Thomas. 2006. "The Backlash Against Democracy Promotion." Foreign Affairs 85(2):55-68.

Carothers, Thomas. 2009a. "Democracy Assistance: Political vs. Developmental?” Journal of Democracy 20(1):5-19.

Carothers, Thomas. 2009b. Revitalizing US Democracy Assistance: The Challenge of USAID. Carnegie Endowment for International Peace.

Carothers, Thomas. 2015. "Democracy Aid at 25: Time to Choose." Journal of Democracy 26(1):59-73.

Charron, Nicholas \& Victor Lapuente. 2011. "Which Dictators Produce Quality of Government?" Studies in comparative international development 46(4):397-423.

Cheibub, José Antonio, Jennifer Gandhi \& James Raymond Vreeland. 2010. “Democracy and Dictatorship Revisited.” Public Choice 143(1-2):67-101.

Collier, Paul. 2006. "Is Aid Oil? An Analysis of Whether Africa Can Absorb More Aid." World development 34(9):1482-1497.

Coppedge, Michael, John Gerring, Carl Henrik Knutsen, Staffan I. Lindberg, Jan Teorell, Nazifa Alizada, David Altman, Michael Bernhard, Agnes Cornell \& M. Steven Fish. 2021. "V-Dem Dataset V11. 1.".

Coppedge, Michael, John Gerring, David Altman, Michael Bernhard, Steven Fish, Allen Hicken, Matthew Kroenig, Staffan I Lindberg, Kelly McMann, Pamela Paxton, Holli A Semetko, Svend-Erik Skaaning, Jeffrey Staton \& Jan Teorell. 2011. "Conceptualizing and Measuring Democracy: A New Approach.” Perspectives on Politics 9(2):247-267.

Dahl, Robert Alan. 1989. Democracy and Its Critics. Yale University Press.

Davenport, Christian. 2007a. "State Repression and Political Order." Annual Review of Political Science 10(1):1-23.

Davenport, Christian. 2007b. "State Repression and the Tyrannical Peace." Journal of Peace Research 44(4):485-504. 
de la Croix, David \& Clara Delavallade. 2014. "Why Corrupt Governments May Receive More Foreign Aid.” Oxford Economic Papers 66(1):51-66.

de Zeeuw, Jeroen. 2005. "Projects Do Not Create Institutions: The Record of Democracy Assistance in Post-Conflict Societies." Democratization 12(4):481-504.

Diamond, Larry. 2002. "Elections Without Democracy: Thinking about Hybrid Regimes." Journal of Democracy 13(2):21-35.

Diaz-Cayeros, Alberto, Beatriz Magaloni \& Barry R Weingast. 2003. "Tragic Brilliance: Equilibrium Party Hegemony in Mexico.” Hoover Institution, Stanford University .

Dietrich, Simone. 2013. "Bypass or Engage? Explaining Donor Delivery Tactics in Foreign Aid Allocation.” International Studies Quarterly 57(4):698-712.

Dilorenzo, Matthew. 2018. "Bypass Aid and Unrest in Autocracies." International Studies Quarterly 62(1):208-219.

Dixon, William J \& Paul D Senese. 2002. "Democracy, Disputes, and Negotiated Settlements." Journal of Conflict Resolution 46(4):547-571.

Djankov, Simeon, Jose G Montalvo \& Marta Reynal-Querol. 2008. "The Curse of Aid." Journal of Economic Growth 13(3):169-194.

Donno, Daniela. 2013. "Elections and Democratization in Authoritarian Regimes." American Journal of Political Science 57(3):703-716.

Dreher, Axel, Peter Nunnenkamp \& Rainer Thiele. 2008. "Does Us Aid Buy Un General Assembly Votes? A Disaggregated Analysis.” Public Choice 136(1-2):139-164.

Dunning, Thad. 2004. "Conditioning the Effects of Aid: Cold War Politics, Donor Credibility, and Democracy in Africa." International organization 58(02).

Dupuy, Kendra E., James Ron \& Aseem Prakash. 2015. "Who Survived? Ethiopia's Regulatory Crackdown on Foreign-Funded NGOs." Review of International Political Economy 22(2):419-456.

Epstein, David L, Robert Bates, Jack Goldstone, Ida Kristensen \& Sharyn O'Halloran. 2006. "Democratic Transitions." American Journal of Political Science 50(3):551569.

Fearon, James D. 1994. "Domestic Political Audiences and the Escalation of International Disputes.” American Political Science Review 88(3):577-592.

Finkel, Steven E, Aníbal Pérez-Liñán \& Mitchell A Seligson. 2007. "The Effects of U.S. Foreign Assistance on Democracy Building, 1990-2003." World Politics 59(3):404439. 
Fleck, Robert K \& Christopher Kilby. 2010. “Changing Aid Regimes? U.S. Foreign Aid from the Cold War to the War on Terror." Journal of Development Economics 91(2):185-197.

Frantz, Erica \& Andrea Kendall-Taylor. 2014. “A Dictator's Toolkit: Understanding How Co-Optation Affects Repression in Autocracies." Journal of Peace Research 51(3):332-346.

Gandhi, Jennifer \& Adam Przeworski. 2007. "Authoritarian Institutions and the Survival of Autocrats." Comparative Political Studies 40(11):1279-1301.

Gandhi, Jennifer \& Ellen Lust-Okar. 2009. "Elections Under Authoritarianism.” Annual Review of Political Science 12(1):403-422.

Geddes, Barbara. 1999a. "Authoritarian Breakdown: Empirical Test of a Game Theoretic Argument." Unpublished working paper .

Geddes, Barbara. 1999b. "What Do We Know about Democratization after Twenty Years?” Annual Review of Political Science 2(1):115-144.

Geddes, Barbara. 2003. Paradigms and Sand Castles: Theory Building and Research Design in Comparative Politics. University of Michigan Press.

Geddes, Barbara, Erica Frantz \& Joseph G Wright. 2014. "Military Rule.” Annual Review of Political Science 17(1):147-162.

Geddes, Barbara, Joseph Wright \& Erica Frantz. 2014. "Autocratic Breakdown and Regime Transitions: A New Data Set.” Perspectives on Politics 12(02):313-331.

Gerring, John, Tore Wig, Wouter Veenendaal, Daniel Weitzel, Jan Teorell \& Kyosuke Kikuta. 2020. "Why Monarchy? The Rise and Demise of a Regime Type." Comparative Political Studies p. 0010414020938090.

Gerschewski, Johannes. 2013. “The Three Pillars of Stability: Legitimation, Repression, and Co-Optation in Autocratic Regimes." Democratization 20(1):13-38.

Gibler, Douglas M. 2009. International Military Alliances, 1648-2008. CQ Press.

Gibney, Mark, Linda Cornett, Reed Wood, Peter Haschke, Daniel Arnon, Attilio Pisano, Gray Barrett \& Baekkwan Park. 2020. “The Political Terror Scale 1976-2019.”.

Gleditsch, Nils Petter, Peter Wallensteen, Mikael Eriksson, Margareta Sollenberg \& Havard Strand. 2002. "Armed Conflict 1946-2001: A New Dataset." Journal of Peace Research 39(5):615-637.

Goemans, H E. 2008. “Which Way Out?” Journal of Conflict Resolution 52(6):771-794.

Goldsmith, Arthur A. 2001. "Foreign Aid and Statehood in Africa." International organization 55(1):123-148. 
Greene, Kenneth F. 2010. "The Political Economy of Authoritarian Single-Party Dominance." Comparative Political Studies 43(7):807-834.

Gutting, Raynee \& Martin C Steinwand. 2015. "Donor Fragmentation, Aid Shocks, and Violent Political Conflict." Journal of Conflict Resolution 61(3):643-670.

Hadenius, Axel \& Jan Teorell. 2007. "Pathways from Authoritarianism.” Journal of Democracy 18(1):143-157.

Hailegebriel, Debebe. 2010. "Restrictions on Foreign Funding of Civil Society." The International Journal of Not-for-Profit Law 12(3).

Held, David. 2006. Models of Democracy. 3rd ed. Polity Press.

Hoeffler, Anke \& Verity Outram. 2011. "Need, Merit, or Self-Interest-What Determines the Allocation of Aid?" Review of Development Economics 15(2):237-250.

Houle, Christian. 2015. "Ethnic Inequality and the Dismantling of Democracy: A Global Analysis." World Politics 67(03):469-505.

Humphrey, Chris \& Katharina Michaelowa. 2013. "Shopping for Development: Multilateral Lending, Shareholder Composition and Borrower Preferences." World Development 44:142-155.

Huntington, Samuel P. 1968. Political Order in Changing Societies. New Haven: Yale University Press.

Kahl, Colin H. 1998. "Constructing a Separate Peace: Constructivism, Collective Liberal Identity, and Democratic Peace." Security Studies 8(2-3):94-144.

Kailitz, Steffen. 2013. "Classifying Political Regimes Revisited: Legitimation and Durability." Democratization 20(1):39-60.

Kalyvitis, Sarantis \& Irene Vlachaki. 2010. "Democratic Aid and the Democratization of Recipients." Contemporary Economic Policy 28(2):188-218.

Kapfer, Steve, Rich Nielsen \& Daniel Nielson. 2007. If You Build It, Will They Come? Foreign Aid's Effects on Foreign Direct Investment. In MPSA National Conference.

Kaufmann, Daniel \& Aart Kraay. 2020. “The Worldwide Governance Indicators (WGI) Project.".

Knack, Stephen. 1999. Aid Dependence and the Quality of Governance: A Cross-Country Empirical Analysis. Policy Research Working Papers The World Bank.

Knack, Stephen. 2004. "Does Foreign Aid Promote Democracy?” International Studies Quarterly 48(1):251-266.

Knutsen, Carl Henrik, Håvard Mokleiv Nygård \& Tore Wig. 2017. “Autocratic Elections: Stabilizing Tool or Force for Change?" World Politics 69(1):98-143. 
Kono, Daniel Yuichi, Gabriella R Montinola \& Nicholas Verbon. 2015. "Helping Hand or Heavy Hand? Foreign Aid, Regime Type and Domestic Unrest." International Political Science Review 36(4):409-424.

Kuziemko, Ilyana \& Eric Werker. 2006. "How Much Is a Seat on the Security Council Worth? Foreign Aid and Bribery at the United Nations." Journal of Political Economy 114(5):905-930.

Lai, Brian \& Daniel S Morey. 2006. "Impact of Regime Type on the Influence of U.S. Foreign Aid." Foreign Policy Analysis 2(4):385-404.

Levitsky, Steven \& Lucan A Way. 2006. "Linkage Versus Leverage: Rethinking the International Dimension of Regime Change." Comparative Politics 38(4):379-400.

Levitsky, Steven \& Lucan A Way. 2010a. Competitive Authoritarianism: Hybrid Regimes After the Cold War. Cambridge, UK: Cambridge University Press.

Levitsky, Steven \& Lucan A Way. 2010b. "Why Democracy Needs a Level Playing Field." Journal of Democracy 21(1):57-68.

Lipset, Seymour Martin. 1959. "Some Social Requisites of Democracy: Economic Development and Political Legitimacy.” American Political Science Review 53(1):69-105.

Lucas, Russell E. 2004. "Monarchical Authoritarianism: Survival and Political Liberalization in a Middle Eastern Regime Type." International Journal of Middle East Studies 36(1):103-119.

Magaloni, Beatriz. 2008. "Credible Power-Sharing and the Longevity of Authoritarian Rule." Comparative Political Studies 41(4-5):715-741.

Magaloni, Beatriz, Jonathan Chu \& Eric Min. 2013. "Autocracies of the World, 19502012.” Version 1.0. Dataset, Stanford University .

Magaloni, Beatriz \& Ruth Kricheli. 2010. "Political Order and One-Party Rule.” Annual Review of Political Science 13(1):123-143.

Maoz, Zeev \& Bruce Russett. 1993. "Normative and Structural Causes of Democratic Peace, 1946-1986." American Political Science Review 87(03):624-638.

Marshall, Monty G. \& Ted Robert Gurr. 2020. Polity5: Political Regime Characteristics and Transitions, 1800-2018, Dataset Users' Manual. Center for Systemic Peace.

Martin, Michael F. 2013. US Sanctions on Burma: Issues for the 113th Congress. Number R42939 in "CRS Report" Washington, DC: Congressional Research Service.

Menaldo, Victor. 2012. "The Middle East and North Africa's Resilient Monarchs." The Journal of Politics 74(3):707-722. 
Milner, Helen V \& Keiko Kubota. 2005. "Why the Move to Free Trade? Democracy and Trade Policy in the Developing Countries." International organization 59(1):107143.

Møller, Jørgen \& Svend-Erik Skaaning. 2013. "Autocracies, Democracies, and the Violation of Civil Liberties.” Democratization 20(1):82-106.

Morgenthau, Hans. 1962. “A Political Theory of Foreign Aid.” American Political Science Review 56(2):301-309.

Morrison, Kevin M. 2009. "Oil, Nontax Revenue, and the Redistributional Foundations of Regime Stability.” International organization 63(1):107-138.

Munck, Gerardo L \& Jay Verkuilen. 2002. "Conceptualizing And Measuring Democracy: Evaluating Alternative Indices." Comparative Political Studies 35(1):5-34.

Neumayer, Eric. 2003a. "Do Human Rights Matter in Bilateral Aid Allocation? A Quantitative Analysis of 21 Donor Countries." Social Science Quarterly 84(3):650-666.

Neumayer, Eric. 2003b. "Is Respect for Human Rights Rewarded-An Analysis of Total Bilateral and Multilateral Aid Flows.” Human Rights Quarterly 25:510-527.

Neumayer, Eric \& Thomas Plümper. 2011. "Foreign Terror on Americans." Journal of Peace Research 48(1):3-17.

Nielsen, Richard A, Michael G Findley, Zachary S Davis, Tara Candland \& Daniel L Nielson. 2011. "Foreign Aid Shocks as a Cause of Violent Armed Conflict." American Journal of Political Science 55(2):219-232.

Paget, Dan. 2017. "Tanzania: Shrinking Space and Opposition Protest." Journal of Democracy 28(3):153-167.

Perl, Raphael F. 2007. National Strategy for Combating Terrorism: Background and Issues for Congress. Number RL34230 in "CRS Report" Washington, DC: Congressional Research Service.

Poe, Steven C., C. Neal Tate \& Linda Camp Keith. 1999. "Repression of the Human Right to Personal Integrity Revisited: A Global Cross-National Study Covering the Years 1976-1993.” International studies quarterly 43(2):291-313.

Poe, Steven C. \& James Meernik. 1995. "US Military Aid in the 1980s: A Global Analysis.” Journal of Peace Research 32(4):399-411.

Przeworski, Adam. 1986. Some Problems in the Study of the Transition to Democracy. In Transitions from Authoritarian Rule: Comparative Perspectives, ed. Guillermo O’Donnell, Philippe C Schmitter \& Laurence Whitehead. JHU Press. 
Przeworski, Adam, Michael E Alvarez, José Antonio Cheibub \& Fernando Limongi. 2000. Democracy and Development: Political Institutions and Well Being in the World, 1950-1990. Cambridge University Press.

Reiter, Dan \& Erik R Tillman. 2002. "Public, Legislative, and Executive Constraints on the Democratic Initiation of Conflict.” Journal of Politics 64(3):810-826.

Remmer, Karen L. 1998. “Does Democracy Promote Interstate Cooperation? Lessons from the Mercosur Region.” International Studies Quarterly 42(1):25-51.

Risse-Kappen, Thomas. 1995. Cooperation among Democracies: The European Influence on US Foreign Policy. Vol. 70 Princeton University Press.

Rivera, Mauricio. 2017. “Authoritarian Institutions and State Repression.” Journal of Conflict Resolution 61(10):2183-2207.

Robinson, James A. 2006. "Economic Development and Democracy." Annual Review of Political Science 9(1):503-527.

Rose, Sarah. 2017. "Linking US Foreign Aid to UN Votes: What Are the Implications?" The New York Times.

Ross, Michael L. 2004. "Does Taxation Lead to Representation?” British Journal of Political Science 34(2):229-249.

Russett, Bruce. 1993. Grasping the Democratic Peace. Principles for a Post-Cold War World Princeton University Press.

Russett, Bruce, Christopher Layne, David E Spiro \& Michael W Doyle. 1995. "The Democratic Peace.” International Security 19(4):164-184.

Schedler, Andreas. 2002a. "Elections Without Democracy: The Menu of Manipulation." Journal of Democracy 13(2):36-50.

Schedler, Andreas. 2002b. "The Nested Game of Democratization by Elections." International Political Science Review 23(1):103-122.

Schraeder, Peter J. 2003. "The State of the Art in International Democracy Promotion: Results of a Joint European-North American Research Network." Democratization 10(2):21-44.

Schumpeter, Joseph A. 1942. Capitalism, Socialism and Democracy. New York: Routledge.

Scott, James M. \& Carie A. Steele. 2005. “Assisting Democrats or Resisting Dictators? The Nature and Impact of Democracy Support by the United States National Endowment for Democracy, 1990-99." Democratization 12(4):439-460. 
Sharp, Jeremy M. 2020. Egypt: Background and U.S. Relations. Number RL33003 in "CRS Report” Washington, DC: Congressional Research Service.

Stier, Sebastian. 2014. "Democracy, Autocracy and the News: The Impact of Regime Type on Media Freedom.” Democratization 22(7):1273-1295.

Stone, Randall W. 2004. "The Political Economy of IMF Lending in Africa." American Political Science Review 98(04):577-591.

Sullivan, Patricia L, Brock F Tessman \& Xiaojun Li. 2011. "US Military Aid and Recipient State Cooperation.” Foreign Policy Analysis 7(3):275-294.

Swedlund, Haley J. 2017. The Development Dance: How Donors and Recipients Negotiate the Delivery of Foreign Aid. Cornell University Press.

Sylvan, David \& Stephen Majeski. 2009. US Foreign Policy in Perspective: Clients, Enemies and Empire. Routledge.

Talmadge, Caitlin. 2015. The Dictator's Army: Battlefield Effectiveness in Authoritarian Regimes. Cornell University Press.

Teorell, Jan. 2010. Determinants of Democratization: Explaining Regime Change in the World, 1972-2006. Cambridge University Press.

Tierney, Michael J, Daniel L Nielson, Darren G Hawkins, J Timmons Roberts, Michael G Findley, Ryan M Powers, Bradley Parks, Sven E Wilson \& Robert L Hicks. 2011. "More Dollars than Sense: Refining Our Knowledge of Development Finance Using AidData." World Development 39(11):1891-1906.

Toledo, Hugo. 2013. "The Political Economy of Emiratization in the UAE." Journal of Economic Studies .

UNCTAD. 2004. The Least Developed Countries Report 2004. New York: United Nations.

USAID. 1998. Handbook of Democracy and Governance Program Indicators. Technical Publication Series Washington D.C.: USAID.

Voeten, Erik, Anton Strezhnev \& Michael Bailey. 2009. "United Nations General Assembly Voting Data.".

Wahman, Michael, Jan Teorell \& Axel Hadenius. 2013. "Authoritarian Regime Types Revisited: Updated Data in Comparative Perspective." Contemporary Politics 19(1):19-34.

Wang, Yu. 2016. “The Effect of Bargaining on US Economic Aid.” International Interactions 42(3):479-502. 
Welzel, Christian \& Ronald Inglehart. 2006. "Emancipative Values and Democracy: Response to Hadenius and Teorell." Studies in comparative international development 41(3):74-94.

Winters, Matthew S \& Gina Martinez. 2015. "The Role of Governance in Determining Foreign Aid Flow Composition.” World Development 66:516-531.

Wolff, Jonas \& Hans Joachim Spanger. 2017. “The Interaction of Interests and Norms in International Democracy Promotion." Journal of International Relations and Development 20(1):80-107.

Wooldridge, Jeffrey M. 2016. Introductory Econometrics: A Modern Approach, 6e. Cengage Learning.

World Bank. 2021. "World Bank Development Indicators.”.

Yom, Sean L \& F Gregory Gause III. 2012. "Resilient Royals: How Arab Monarchies Hang On.” Journal of Democracy 23(4):74-88.

Yom, Sean L. \& Mohammad H. Al-Momani. 2008. "The International Dimensions of Authoritarian Regime Stability: Jordan in the Post-Cold War Era." Arab Studies Quarterly pp. 39-60.

Younas, Javed. 2008. "Motivation for Bilateral Aid Allocation: Altruism or Trade Benefits.” European Journal of Political Economy 24(3):661-674. 
DONGJIN KWAK was born in South Korea. He earned his three BAs in Political Science and International Relations, Public Administration, and Economics from Kyung Hee University in Korea in 2013. He also earned his MA in Political Science from Kyung Hee University in Korea in 2016. He started his doctoral program in the Department of Political Science at the University of Missouri in 2016 and earned his Ph.D. in 2021. His study focuses on the fields of international relations and comparative politics. His current research interests are foreign aid, democratization, and civil conflict. 